Portland State University

PDXScholar

$5-5-1992$

\title{
A Cycle of Crisis and Violence : the Oregon State Penitentiary, 1866-1968
}

Joseph Willard Laythe

Portland State University

Follow this and additional works at: https://pdxscholar.library.pdx.edu/open_access_etds

Part of the Criminology Commons, and the History Commons

Let us know how access to this document benefits you.

\section{Recommended Citation}

Laythe, Joseph Willard, "A Cycle of Crisis and Violence : the Oregon State Penitentiary, 1866-1968" (1992). Dissertations and Theses. Paper 4367.

https://doi.org/10.15760/etd.6224

This Thesis is brought to you for free and open access. It has been accepted for inclusion in Dissertations and Theses by an authorized administrator of PDXScholar. Please contact us if we can make this document more accessible: pdxscholar@pdx.edu. 
AN ABSTRACT OF THE THESIS OF Joseph Willard Laythe for the Master of Arts in History presented May 5, 1992.

Title: A Cycle of Crisis and Violence: The Oregon State Penitentiary, 1866-1968.

APPROVED BY THE MEMBERS OF THE THESIS COMMITTEE:
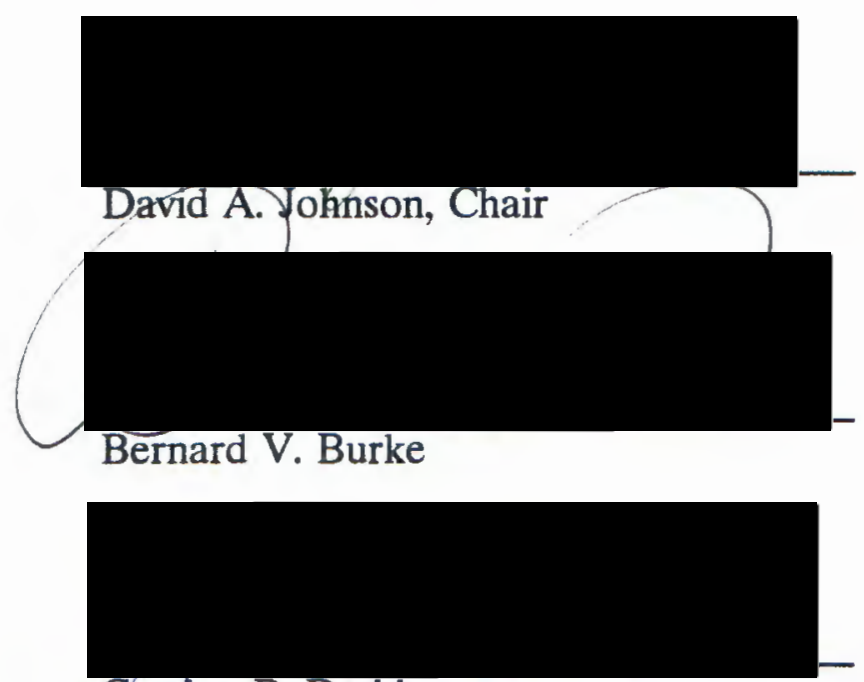

Goredon B. Dodds

Franklin West

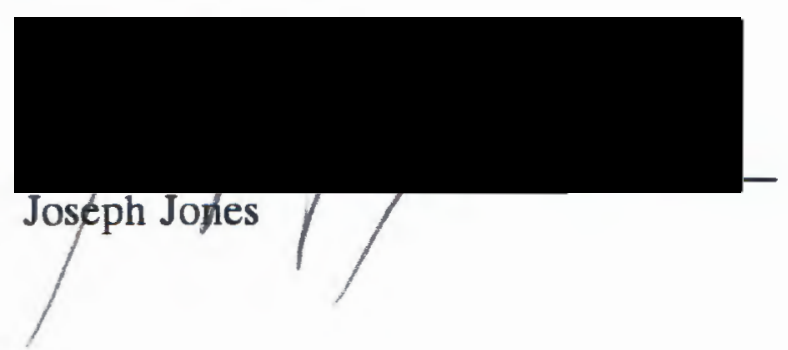


This thesis examines seven crises at the Oregon State Penitentiary between 1866 and 1968 which are symptomatic of a larger pathology of power at play at the institution. These prison crises brought the pathology of power out from behind the thick grey walls of the institution and to the eyes and ears of an uninformed public. This arousal of such attention forced the prison to re-evaluate its penal model, enact half-hearted reforms, but then resume to the institution's traditional pattern and style of punishment. This inability to address the crises or resolve the immediate problem points to a larger problem-namely a pathology of power. The pathology of power is evident in the prison administration's abuse of the political, financial, and physical power that the prison offers. This pathology is innate to the philosophy of the institution, regardless of the penal model then in application (rehabilitative or disciplinary).

Just as these pathologies have remained hidden behind the institution's walls so too has much of the records for the penitentiary. The central records at the Oregon State Penitentiary are in total disarray. What records remain are scattered between the Oregon State Library, the Oregon State Archives, and the Oregon Historical Society. Even then, these records offer little insight into the daily life of the inmate. Quantitative history, using the inmate registers and disciplinary records, has been used to fill this void. Through an examination of these state records, newspapers, prison registries, and general prison history works it becomes abundantly clear that the institution is a "failure" in that it fails to deter, reform, or warehouse Oregon's deviant classes. This failure is not confined 
only to the Oregon State Penitentiary, but is a phenomenon throughout all prisons. This thesis exposes the pathology of power, details its symptoms, and describes the "gargantuan" enterprise which has stripped our society of its ability to create an alternative to the prison model. 


\title{
A CYCLE OF CRISIS AND VIOLENCE:
}

THE OREGON STATE PENITENTIARY, 1866-1968

\author{
by \\ JOSEPH WILLARD LAYTHE
}

A thesis submitted in partial fulfillment of the requirements for the degree of

\author{
MASTER OF ARTS \\ in \\ HISTORY
}

Portland State University

1992 


\section{TO THE OFFICE OF GRADUATE STUDIES:}

The members of the Committee approve the thesis of

Joseph Willard Laythe presented May 5, 1992:

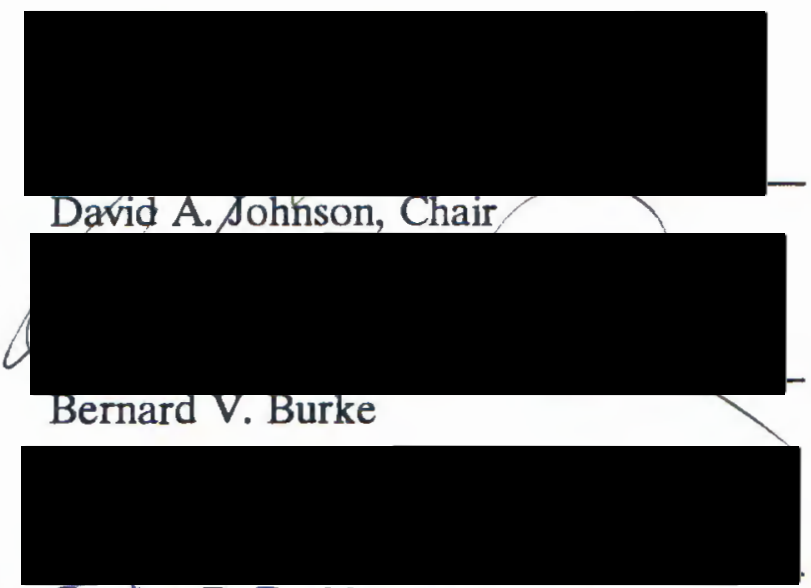

Gordon B. Dodds

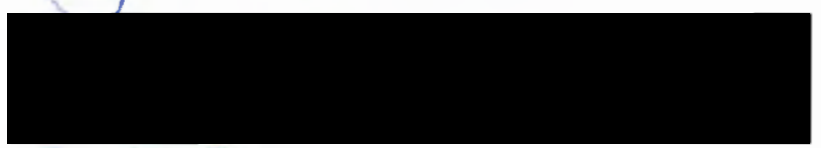

Franklin West

APPROVED:

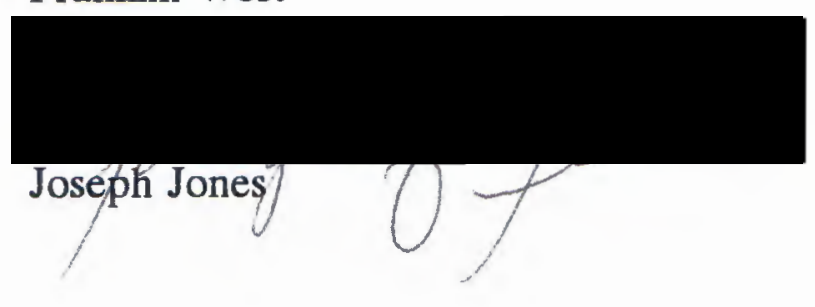

Bernard V. Burke, Chair, Department of History

C. William Savery, Interim Vice Provost for Graduate Studies and Research 


\section{ACKNOWLEDGEMENTS}

Throughout the research and writing of this work I have benefited from the advice of a handful of individuals, all to whom I am indebted.

For kindness, patience, and guidance in every form, I am especially grateful to Dr. Bernard V. Burke, Dr. Gordon Dodds, Dr. Franklin West, and Dr. Charles LeGuin, all of the Portland State University History Department. I am also grateful for the criticisms of the Sociology Department's Dr. Joseph Jones and the Department of Corrections' Theodore S. Long, as well as the technical support of my classmate Cynthia Gardiner.

I am further indebted, however, to the elusive Dr. David A. Johnson without whom this work would not have been produced. I appreciate each fleeting moment spent beneath his critical stare.

Lastly, I must thank my family who have endured long hours of reading, writing, typing, cutting and pasting, and grumbling. I wish to thank my parents Charles and Helen Laythe of Oregon City and my sister, Jeri. And of course, I extend my deepest appreciations to my beautiful wife, Christine. I could not have done it without her. 


\section{TABLE OF CONTENTS}

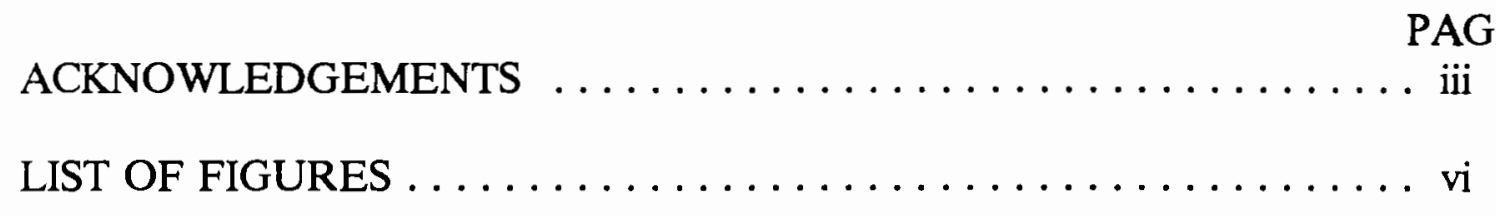

CHAPTER

I INTRODUCTION $\ldots \ldots \ldots \ldots \ldots \ldots \ldots \ldots \ldots \ldots \ldots \ldots \ldots$

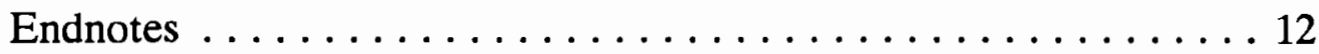

II "NOTHING BUT IRON AND RIFLES": $1866-1882 \ldots \ldots \ldots \ldots 14$

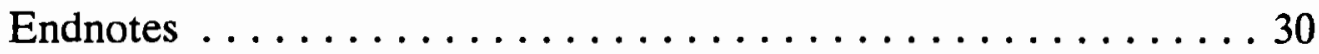

III "SHOOT AND BE GOD DAMNED": 1883-1901 .......... 32

Endnotes $\ldots \ldots \ldots \ldots \ldots \ldots \ldots \ldots \ldots \ldots \ldots \ldots, 42$

IV "TO HATCH TROUBLE": 1902-1914 ................ 44

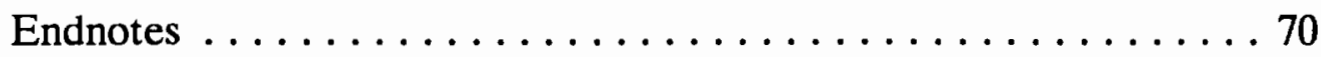

V "A CHANNEL FOR THEIR ANGER": 1915-1925 ......... 73

Endnotes $\ldots \ldots \ldots \ldots \ldots \ldots \ldots \ldots \ldots \ldots \ldots . \ldots 2$

VI "HAVEN FOR BEAST": 1926-1938 . . . . . . . . . . . 95

Endnotes ............................. 117

VII "THE GRAVEYARD OF WARDENS": 1939-1953 . . . . . . . 121

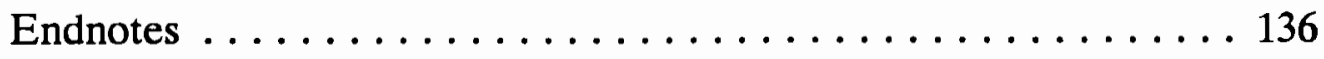


VIII "EVERY MAN REACHES HIS BREAKING POINT": 1954-1968 138

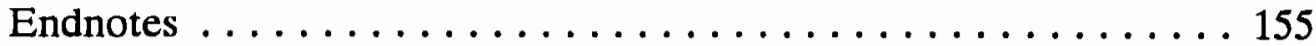

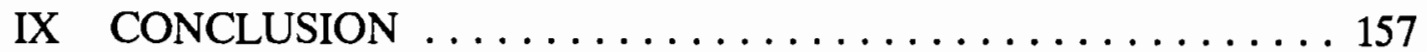

SELECTED BIBLIOGRAPHY . . . . . . . . . . . . . 159 


\section{LIST OF FIGURES}

FIGURE

PAGE

1. Oregon State Penitentiary Escapes, $1866-1872 \ldots \ldots 22$

2. Oregon State Penitentiary Escapes, $1872-1883 \ldots \ldots \ldots 35$

3. Oregon State Penitentiary Escapes, 1900-1924 . . . . . . . . 66

4. Behavior-Discipline Ranking, Sample of 265 Inmates at the Oregon State Penitentiary, $1909-1919$. . . . . . . . . . 68 


\section{CHAPTER I}

\section{INTRODUCTION}

In a pool of blood, Oregon Department of Corrections Director Michael Francke lay dead. To many of the institution's critics his January 1989 murder remains unsolved. This type of tragic occurrence, however, was not new to Oregon Corrections. In 1883 the penitentiary's warden was seized by a body of armed convicts and only released after the inmates were guaranteed their freedom. In 1915 the warden was shot and killed by an escapee. How is it that after one hundred years of supposed advancement that a corrections director can still be a victim of the institution? Are there recurrent themes in prison history? Is there a recurring cycle of crisis and ineffective response that plagues the Oregon State Penitentiary? While the magnitude of each "crisis" may vary they have all played a pivotal role by influencing, in subtle and overt ways, the course of penology in Oregon. They have all, in their own ways, resurrected the dilemma of how to respond to prison crises; the choice being between a rehabilitative or disciplinary model or some other radical alternative.

Prisons do indeed contain inherent pathologies in the sense that there are pressures from within and without that destroy the concentration of power and the mechanisms of social control. Pressures from social reformers and political 
demands are forced onto the prison from the outside. Internal pressures, like physical and financial abuse, also cripple the institution. The crises outlined in this work are symptomatic of a larger problem--a pathology of power. These inherent pathologies reveal the complexities which give the prison its paradoxical nature and, as a result, intensify and perpetuate the cycle of crisis and ineffective response that plagues the institution and prevents the prison from making qualitative leaps of "progress." This is to say that the prison has not changed much since its nineteenth-century birth. Only technological advancements have occurred. At the Oregon State Penitentiary there has been change without change.

The lack of true "change" at the institution, however, is rarely seen by the general public. Those changes made are subtle even to those who are sophisticated in prison theory and practice. The pathologies of the prison remain hidden behind its thick grey walls and mechanized locks. The prison is an abstraction, away from town, out of view. It occupies only the margins of public awareness; the same public it is meant to serve.

Michel Foucault has discussed this paradox in his work, Discipline and Punish. ${ }^{1}$ By confining criminals and isolating them behind walls and bars, Foucault argues, social dependents and deviants leave the everyday consciousness of the general public and enter a remote and abstract sphere. He further asserts that reformers do not focus on the abuse of power within the institution, but rather emphasize an "economy of power." Their goal is to not punish less, but to 
punish better. "From being an art of unbearable sensations," Foucault argues, "punishment has become an economy of suspended rights." $\mathrm{A}$ theme in Oregon prison history, consistent with Foucault's argument, is the on-going struggle between the therapeutic and disciplinary techniques in punishment philosophy. The therapeutic philosophy is based on the belief in the inherent "good" in all humans. Because of these innate positive qualities, so reasons the therapeuticallyminded, inmates can be reformed and returned to society as model citizens. In contrast, the disciplinary philosophy argues that inmates are incorrigible criminals that must be isolated and physically punished.

The body had been the focus of punishment for centuries. The focus in twentieth-century penal philosophy, however, has seen a shift from a punishment of the body to a punishment of the soul. This dramatic transformation is seen in Oregon's prison history as administrators slowly abandoned harsh disciplinary techniques like the "Oregon Boot" and adopted seemingly more humane measures like isolation and classification. The struggle between these two philosophies has plagued the institution in Salem since its origins. Furthermore, it is this philosophical and practical struggle that has helped perpetuate the cycle of crisis and equilibrium and sustain the "change without change" phenomenon.

From an external vantage point the prison seems to be effective in serving public needs. The prison, however, also serves the powerful and power-hungry as a tool of social control. The prison administration, staff, and politicians have continually exploited the opportunities the penitentiary offered. The Oregon State 
Penitentiary in Salem is just the type of institution that Foucault described. On the outskirts of Salem it is largely a forgotten institution.

The murder of Michael Francke in January 1989 returned the Oregon State Penitentiary to the forefront of public attention. As in times past, crisis, regardless of magnitude, overtook the prison and captured the attention of an uninformed public. While not every escape or uprising constitutes a crisis, the seven events detailed in this account did constitute a crisis in that they brought the prison's failures to the attention of the general public. The principal concern of the public in the Francke tragedy involved a supposed internal "conspiracy" to murder Francke, but the controversial strands actually weave much deeper. Before he became Corrections Director, Francke had served as the Assistant Attorney General in New Mexico. Nine years after the prison tragedy at Attica the most grisly of prison riots in the nation occurred on the outskirts of Santa $\mathrm{Fe}$ at the New Mexico State Prison. Twelve guards were taken hostage and thirty-nine inmates killed. This blood frenzy was placed into local and national context by Roger Morris's work, The Devil's Butcher Shop.

Morris pointed to poor conditions and incompetence on the part of New Mexico officials as the cause of the disturbance. While nothing of this scale has ever occurred in Oregon the causes of the disturbance parallel much of Oregon's prison past. Part of the blame for the New Mexico tragedy was directed toward Assistant Attorney General Michael Francke. While Francke compelled the state to improve classification practices, reduce overcrowding, and improve conditions 
he was also the foremost advocate of legalizing and standardizing prison discipline. Francke was an advocate of the disciplinary philosophy in penology and thus ran counter to the then prevailing philosophy of rehabilitation. According to Morris, a second blunder on the part of Francke was that his official reports masked responsibility for the mass escapes that preceded the riot. Morris maintains that Francke "has no experience running a prison, let alone administering a statewide penal system. But he is said to have fresh ideas and the governor's confidence."13

Francke's murder, like the crises detailed in this work, brought the prison from the periphery of social consciousness to the forefront of attention. In doing so, the public and prison administration must deal with how to respond to the crisis, prevent future crises, and what penological model will best serve these purposes. This incident involving Francke only reveals the depth to which the purpose of the prison penetrates society. Indeed, prisons cannot be separated from the society they serve. As David Rothman observes in his landmark account, The Discovery of the Asylum, "Institutions, whether social, political, or economic, cannot be understood apart from the society in which they flourished." 4 In his unique explanation Rothman believes that American social welfare institutions are products of the eighteenth and nineteenth century where there was a "...vigorous attempt to promote the stability of the society at a moment when traditional ideas and practices appeared outmoded, constricted, and ineffective." ${ }^{15}$ In other words, nineteenth-century institutional development marked an attempt to recapture a past stability in an age of change, confusion, and chaos by applying the most 
modern techniques of that age. In Oregon this was, indeed, the case as pioneers sought to reestablish stability in a frontier environment, through many institutions, including the penitentiary.

While they occupy a marginal place in social awareness, prisons are essential to an understanding of any society. The manner in which society handles those who deviate from the standards of behavior reveals much about the beliefs, principles, and vision of that society. Prisons are, as Lester Douglas Johnson remarks, "tragic monuments to the inability of the human race to come to grips with...those members who have not fulfilled the social contract." ${ }^{\text {"6 }}$ After "expulsion" society's response to deviant behavior has traditionally focused on incarceration. Planned and programmed responses to deviance, however, are simply not effective because of inherent weaknesses within the prison, including the pathology of power. Because prisoners are individuals who have failed to uphold their share of the general social contract, society feels no urgent need to rehabilitate or reinvigorate the institution. Nor does society seek effective measures to truly deter crime and social deviance.

The crisis and equilibrium in prison history is nothing new. The story of many prisons is a history of alternating episodes of violence and crisis with periods of stabilization and equilibrium. Focusing attention on this point, Gresham Sykes in 1958 altered our understanding of social control and prison history with his work, The Society of Captives. ${ }^{7}$ His often cited theory of "crisis and equilibrium" has been the bedrock of more recent prison histories which are marked with 
alternating periods of chaos and stability. In Oregon's case, as I will argue, these alternating periods are punctuated by episodes in which politically appointed administrators grappled with an unruly population and prison reformers.

Throughout Oregon's prison history, each administration's response to crisis has been unique. But in each case, their actions have not stemmed future incidents of violence or crisis. They have not addressed the pathology, but rather bandaged a symptom. These continual failures have helped perpetuate the cyclical history of the institution. As long as the prison is offered as a remedy for itself, the crises and problems like those recorded in this account, will continue.

Throughout this work we will see how political, financial, and physical power disrupted the "effectiveness" of the Oregon State Penitentiary and brought it serially to crisis. A crisis, as defined in this work, is a crucial turning point in the course of penal affairs. It is, furthermore, an event that because of its severity has jeopardized not only the public, but also the political and prison administrations of the period. In Oregon the events of $1866,1883,1902,1915$, 1925,1953 , and 1968 posed as crises because they jeopardized the safety of the general public, threatened the prison administration, and brought the therapeuticdisciplinary philosophical struggle to the forefront of public attention. The prison administration, in each case, was faced with the dilemma of how to respond. Were they to respond with force or buckle to pressure and grant greater leniency. Each chapter discusses the origin of a specific historical crisis, details the crisis, and then describes the resulting tension that leads into the subsequent crisis. 
Chapters One and Two, entitled "Nothing But Iron and Rifles" and "Shoot and Be God Damned", focus on the absence of reformative or rehabilitative policy that led to the prison crises of 1866 and 1883. The third, fourth, and fifth chapters center the discussion on politics and reform that contributed to the crises of 1902,1915, and 1925. Entitled "To Hatch Trouble", "A Channel for their Anger", and "Haven for Beast", these chapters also describe the prison's policy that contributed to crisis. The last two chapters examine the social forces and politics that were the instrumental factors behind the modern strikes and riots of the 1950s and the "Great Riot" of 1968. The history of the Oregon State Penitentiary revolves around these crises, briefly passing through reform and deterioration, but always returning to a crisis again. ${ }^{8}$

For the prison the "cycle", or on-going crisis, is the constant struggle between public and private interest. Visions of Social Control by Stanley Cohen highlights this paradox. ${ }^{9}$ He covers the range of emotions that prison administrators in confronting criminals experience: hatred, revenge, disgust, compassion, salvation, as well as admiration. Along these lines, Cohen maps out the transformation of penology and social control in the twentieth century. Like Foucault, he illustrates the transformation from a concentration on punishing the body to a punishment of the soul. Unlike Foucault, he sees the latter, tolerant and "liberal," tendencies as positive marks of social advance. The supposed "rehabilitative" advancements in Oregon penology, like the abandonment of the "Oregon Boot", he implies, is evidence of this "liberal progress." But is this truly a 
"change" for the better?

Originally created to deter crime, the Oregon State Penitentiary quickly took on the characteristics of the society it sought to serve. From its origins in Oregon City the institution has been plagued with violence, politics, and financial hardship. Since 1846 deterrence has failed to be the explicit goal of the institution.

Deterrence, Henry Pontell asserts, involves a weighing of costs and benefits and translating that into action. In A Capacity to Punish, Pontell focuses on the impact of legal sanctions on rates of serious crimes in the population. ${ }^{10} \mathrm{He}$ concludes that deterrence is of far greater value to those of higher economic status "...who necessarily have more to lose by engaging in crime." ${ }^{11}$ This, in part, helps explain the disproportionate presence of Indians, immigrants (in Oregon primarily Catholics), Blacks, Chinese, and Mexicans in the Oregon State Penitentiary's historical population.

Erik Olin Wright furthers the discussion in his account, The Politics of Punishment. ${ }^{12}$ Consumption values in the United States, Wright asserts, intensify the criminal and prison crisis by narrowing the options available in society for social mobility. When the poor accept these values of consumption they are placed in an extremely precarious situation since they lack the means to achieve these products and status symbols. As a result, prisons throughout the country, including Oregon, have become warehouses of disorder and poverty. All of the wardens at the Oregon State Penitentiary were intelligent, 
systematic men, but each one was more concerned with preserving his position and perpetuating the institution than in reforming the institution and rehabilitating the inmates. Their authoritarian principles did not rehabilitate, but punished an already oppressed class of people. Following each authoritarian regime came a period of half-hearted reform, and with such came heightened tensions between hopeful convicts and the crippled authorities. Lester Douglas Johnson, a former inmate, presents this idea in his work, The Devil's Front Porch.

While the privation of liberty is one principal means of punishment and oppression, Johnson believes that much of the aggression seen in prisons today is the result of a convict's frustration with the increasingly more tolerant and progressive environment around him. When an inmate becomes aware of the liberal activities surrounding him $\rightarrow$ such as rights extended to Blacks, women, and other marginal social groups-he comes to expect that these social reforms and freedoms will be extended to prison society. However, when these expectations are not realized (or not achieved as rapidly as expected) the prisoner grows disenchanted and eventually lashes out at the administration. "Privation," Johnson asserts,"is far less cruel and less likely to cause violence than is the dashing of hopes."13 And hope is the product of prison reform and social liberalization. Outside interest groups have always made demands on the prison authorities and held them accountable to current social trends. These outside forces, however, cripple the administration's authority, enabling prison unrest to escalate to immense proportions. Reform measures in Oregon, as we shall see, 
have typically followed this pattern.

Riots, in turn, set off eruptions of political scape-goating and handwringing. Riots return the prison to public attention. Intense scrutiny of the institution, in Oregon's case, generally resulted in a re-evaluation of the two punishment theory models (therapeutic and disciplinary) and eventually ended in the removal of the incumbent warden. His replacement carried out a few "reforms", but then returned to an authoritarian policy. The "cycle" of events has then made a full turn. This is the paradox of the penitentiary.

The story of the prison, however, also reveals a determination of politicians and prison administrators to perpetuate established power rather than make the institution an effective instrument serving society and its incarcerated population. The prison, in this regard, has been a tool of power. It provided positions for political allies, financially profited the prison administration through contracts and privileges, and served as a tool of vengeance. The prison has been used continually to assert power financially, physically, and politically. This pathology fuels the vicious cycle that flows from crisis, through stagnation and equilibrium, and back to crisis again.

Through this examination of the penitentiary's cycle of crisis and equilibrium and the delineation of change without change it seems that perhaps the true "progress" society seeks in penal affairs is a futile chase toward an impossible goal. 


\section{ENDNOTES}

${ }^{1}$ Michel Foucault, Discipline and Punish: The Birth of the Prison (New York: Pantheon Books, 1977).

${ }^{2}$ Ibid., 11.

${ }^{3}$ Ibid., 226.

${ }^{4}$ David Rothman, The Discovery of the Asylum: Social Order and Disorder in the New Republic, (Boston: Little, Brown, and Company, 1971), xx.

${ }^{5}$ Ibid., xviii.

${ }^{6}$ Lester Douglas Johnson, The Devil's Front Porch (Lawrence, KS: The University Press of Kansas, 1970).

${ }^{7}$ Gresham Sykes, The Society of Captives: A Study of a Maximum Security Prison (Princeton: Princeton University Press, 1958).

${ }^{8}$ While many historians criticize the cycle of history theory, I think there are certain recurring themes throughout the Oregon State Penitentiary's history worthy of examination. R.G. Collingwood, a philosopher of history, once wrote:

The historical cycle is a permanent feature of all historical thought; but wherever it occurs, it is incidental to a point of view. The cycle is the historian's field of vision at a given moment....Some system of cycles there must always be for every historical student, as every man's shadow must fall somewhere on his own landscape; but as his shadow moves with every movement he makes, so his cyclical view of history will shift and dissolve, decompose and recompose itself anew, with every advance in the historical knowledge of the individual and the race.

From R.G. Collingwood, Essays in the Philosophy of History, (Austin, 1965), $75,89$.

${ }^{9}$ Stanley Cohen, Visions of Social Control: Crime, Punishment, and Classification (Cambridge: Polity Press, 1985).

${ }^{10}$ Henry Pontell, A Capacity to Punish: The Ecology of Crime and Punishment (Bloomington, Indiana: Indiana University Press, 1984).

${ }^{11}$ Ibid., 7. 
${ }^{12}$ Erik Olin Wright, The Politics of Punishment: A Critical Analysis of Prisons in America (New York: Harper and Row, 1973).

${ }^{13}$ Johnson, The Devil's Front Porch, xi. 


\section{CHAPTER II}

\section{"NOTHING BUT IRON AND RIFLES": 1866-1882}

The first major incident of violence at the Oregon State Penitentiary occurred on August 27, 1866. Just seventeen days prior to the expiration of his term of office, Superintendent Alva C. R. Shaw, Warden Allard, and Brickyard Foreman Alden were seized by a large body of armed prisoners. Wielding butcher knives and crude hand-made weapons, the inmates marched Superintendent Shaw toward the edge of the stockade. As they did so, Shaw resisted and ordered the guards on the platforms to open fire into the mass of convicts. Several prisoners broke free and fled into the woods adjacent to the penitentiary grounds. One convict was fatally wounded. Officers with picks, shovels, and clubs forced the remaining convicts to retreat back to their cells. Eight of the convicts escaped into the woods. ${ }^{1}$

It was no wonder that convicts risked their lives for freedom. Conditions within the prison were deplorable. Danger of fire and a poor sewage system, coupled with primitive prison policy and brutal overseers, made prison life harsh and inhumane. The administration's only attempt at reform was through the employment of inmate labor. "Constant systematic employment," Governor L.F. Grover later said, "is probably one of the most humane, and at the same time, one 
of the most valued means of reform used in public prisons."2

But was reform truly the intent of the new penitentiary? In the 1840 s and 1850s Oregon's political leaders debated the necessity of the institution, but did not once discuss its purpose, let alone the value of reformation or rehabilitation within the prison. Oregon's pioneer leaders assumed the penitentiary's purpose was to isolate those who failed to uphold standards of behavior established by the current political leaders. It was a warehouse, not a reformatory. Four decades after its founding, Superintendent A. N. Gilbert echoed these sentiments when he stated that he never regarded the prison as a reformatory. The Oregon State Penitentiary was not unique in this respect-prisons throughout the West were primitive renditions of Eastern institutions. Eastern political leaders adopted the principles of penal professionals and established modern, professional, bureaucratic structures. Western prisons, however, were primitive one room dirtfloor cells. The prison was brought West with little ideological base other than the principle of four walls, locks, and bars.

The early history of the Oregon prison system has a parallel in the settlement of all newly inhabited regions. As long as the Anglo-American population was sparse and the settlement consisted of only a few families, the safety and security of the community was easily assumed. The situation in the Willamette Valley changed, however, after the arrival of American overlanders in the mid-1840s. The influx of settlers and the growth of towns in the Oregon Country altered the community's vision of itself. With increasing immigration 
came the typical problems that accompany rapid population expansion: poverty, civil, and criminal disputes. An early edition of the Oregon City Spectator reads, "In most countries almost the first thing that has to be erected after the country begins to grow and increase rapidly in population is a strong hold of some sort for the confinement of the disorderly and the vicious who may come among them."13 The necessity of a jail was debated from the first meeting of the provisional government at Champoeg in March 1843, until long after the prison's construction shortly thereafter. The leaders in the community brought with them their "cultural baggage." Without a clear need for a jail the leaders established the institution simply because their previous communities had chosen to punish deviant members through this method. The conservative Oregon leaders perpetuated the penal principles of their day. They brought eastern institutions and beliefs west and applied them to the rugged frontier. It was only after the Oregon territorial prison was constructed that Oregon's criminal activity began to take on alarming proportions. The jail in Oregon City rarely housed more than one inmate at a time.

Financed by funds from the estate of Oregon cattleman Ewing Young, Oregon's first jailhouse was erected "upon the lofty bluffs that rose majestically above the falls at Oregon City...." The $\$ 875$ structure was a two-story blockhouse with a pitched roof accesible only by an outside staircase. Prisoners were escorted upstairs and dropped to a lower room through a small hole in the center of the floor. "A sentry stood by in the upper room with a club ready to bludgeon the 
head that dared to poke up from the grotesque chamber below." The jail was completed in April 1842. ${ }^{4}$ When the structure was destroyed by an arsonist's fire in August 1846, provisional governor George Abernethy (1845-1849) again questioned the necessity of the jail. Oregon's political scene was far from stable. Territorial and State Administrations were continually fluctuating from one political party to another. Political turmoil and debate over the prison's necessity delayed further progress. By early 1851, however, the territorial legislature agreed to build a territorial prison. A bitter fight broke out among the political powerhouses as to the location of the seat of government. With this came arguments over the location of other state institutions, the penitentiary included.

A site in Portland was selected, however, in February 1853, and construction was completed in early 1854 . Until then Oregon's deviant members were held in a temporary prison at an old Portland whiskey shop run by William King. King, however, was highly criticized for his failure to run an effective prison. "No man could have been found more obnoxious to the people;" the Oregonian read, "or more mulishly determined to use a public office for base and sordid purposes. The appointment was given him partly as a reward for the disgrace he brought upon...the people of Washington County..."5 King was further noted as "totally incompetent" and as a "humbug commissioner."6

King's prison, however, also fell victim to fire in November of 1854. Fortunately, the penitentiary building commissioners had already found a permanent site for the prison. The new territorial penitentiary was constructed in 
southwest Portland on Front Avenue facing the Willamette River. During the construction period, the remaining convicts, those who had not escaped, were placed in the farmhouse of F.M. Arnold, located at Front Avenue between Mill and Montgomery streets. This temporary prison was supervised by three superintendents and F.M. Arnold ,who was titled assistant keeper. Arnold collected three dollars a day for each convict he housed. ${ }^{7}$ The political uncertainties of the territorial period during Oregon's changing government resulted in a high turnover of prison commissioners and superintendents. With such inconsistency, it is no wonder that many outlaws escaped from behind the bars of their makeshift cells. On July 16,1857 , seventeen male inmates and one female prisoner, Charity Lamb, moved into the permanent Portland prison. Nine years later, however, the structure was abandoned for a site in Salem. The political debate over the prison's location had ended and Salem had won.

In November 1857, Commissioner George Sloan complained to the territorial legislature that due to an increase in the prisoner population he felt it necessary to requisition the services of his brother-in-law, C.A. Pickett, as an assistant keeper at the prison. He requested $\$ 1600$ to pay for their combined salaries. ${ }^{8}$ In order to make the institution self-sufficient, the legislature authorized the governor to lease prisoners to private contractors. Robert Newell and Levi English leased the prison and the labor of its convicts and immediately sublet it to Luzerne Besser. It was Besser's responsibility to see to it that the convicts were clothed, fed, and kept secure. He was also responsible for the 
repair and maintenance of the structure. When he assumed control of the prison, he had twenty-five prisoners and shortly thereafter, all twenty-five escaped. Besser quit, and Newell and English subsequently defaulted on their contract. ${ }^{9}$ The policy of leasing the prison labor was not entirely abandoned, however. The prison was a profitable enterprise; financial advantage was available and many took the opportunity to exploit it.

The first recorded prisoner at the territorial jail was Charley Clatawed, a "...lone Indian...convicted of stealing horses...." ${ }^{10}$ Cornelius Sharp was registered as the second prisoner in the institution on February 18, 1854. Sentenced to life for the second-degree murder of Robert McCarther, Sharp was shipped to Portland from Oregon City accompanied by his wife and child. Oregon City was glad to be "...rid of this nuisance."11

In order to understand the internal dynamics of prisons it is important to understand the characters who were involved in the prison. The Portland penitentiary's most renowned inmate, however, was the axe-wielding husbandmurderer Charity Lamb. Charity had split her husband's head with an axe. Stunned by her murderous act, she sat down before the fireplace, glossy-eyed, and smoked a pipe. She returned to his side and said, "Nathaniel, I am here." Aroused by her soft and gentle voice, he opened his eyes and replied, "Yes, dear, I see you are. My dear, why did you kill me for?"12 Nathaniel Lamb died thereafter. Charity and her seventeen year old daughter were both charged with the murder, but finding no evidence to support the daughter's complicity, she was 
soon released. Charity--"Pale and sallow, and as emaciated as a skeleton..."-- was convicted of murder. ${ }^{13}$ Her only testimony: "I didn't mean to kill the critter, I only intended to stun him. ${ }^{14}$ From a modern perspective Charity Lamb's testimony to authorities before trial reveals possible physical abuse by her husband. Historical hindsight, however, cannot save Charity, or Nathaniel, for that matter. Charity Lamb later escaped from behind her bars and was never seen in the Oregon Country again.

Preventing escapes proved to be the most problematic dilemma facing the prison's leaders. The new prison in Salem, it was hoped, would solve this dilemma. The prison, on the swampy banks of Mill Creek, was to be a penal fortress. The effectiveness of the institution, however, hinged largely on the prison's policy and philosophy, not on the thickness of the prison's walls or the force of the guards's harsh blows.

In October of 1862, Governor Addison C. Gibbs was approved as ex-officio superintendent of the penitentiary with the authority to appoint a warden and assistant warden and to remove them at his pleasure. Gibbs appointed Alva C.R. Shaw as superintendent and J.C. Gardner as warden. ${ }^{15}$ Shaw and Gardner maintained control within the penitentiary through one of the cruelest torture devices used in the United States-the Gardner Shackle. Also known as the "Oregon Boot", the shackle was ultimately patented by Warden Gardner in July 1866.

Made in the prison shop, the shackles weighed from five to twenty-five 
pounds each and consisted of a large iron bar connected to braces and secured to the ankle of the convict. Bound in this fashion, it was virtually impossible for the prisoner to move about without pain. ${ }^{16}$ During "Sheep" Shaw's administration, the inmates were tutored in the practical principles of lock-step marching and general obedience. ${ }^{17}$

By May of 1866 the convicts were moved into their new quarters. Shaw's discipline quickly crumbled in Salem. During its first five months in Salem, the present superintendent and warden lost complete control. This absence of control was evident in August 1866, when the prison incurred over one hundred fifteen escapes, indicating a complete turnover of prisoners twice around. ${ }^{18}$

Critical of Shaw's laxity in discipline, the new governor George Woods immediately removed and replaced him with his ally, Major M.P. Berry. With the assistance of Lieutenant Gale of the Oregon Infantry, Major Berry turned the institution into an institution run on military lines. The military model of the penitentiary, even in 1866 , was not new. The quasi-military prison was constructed in order to preserve inmate control, inculcate discipline and regimentation, and enhance labor efficiency. Only military force, penologists at the time believed, was appropriate and capable of stifling prison disorder. It was to be Oregon's remedy for its crisis of order. ${ }^{19}$

Although a completely new endeavour for Berry, the new warden was successful in maintaining a strict budget, preventing wholesale escapes, and helping the institution achieve a degree of self-sufficiency. (See Figure 1.) The 


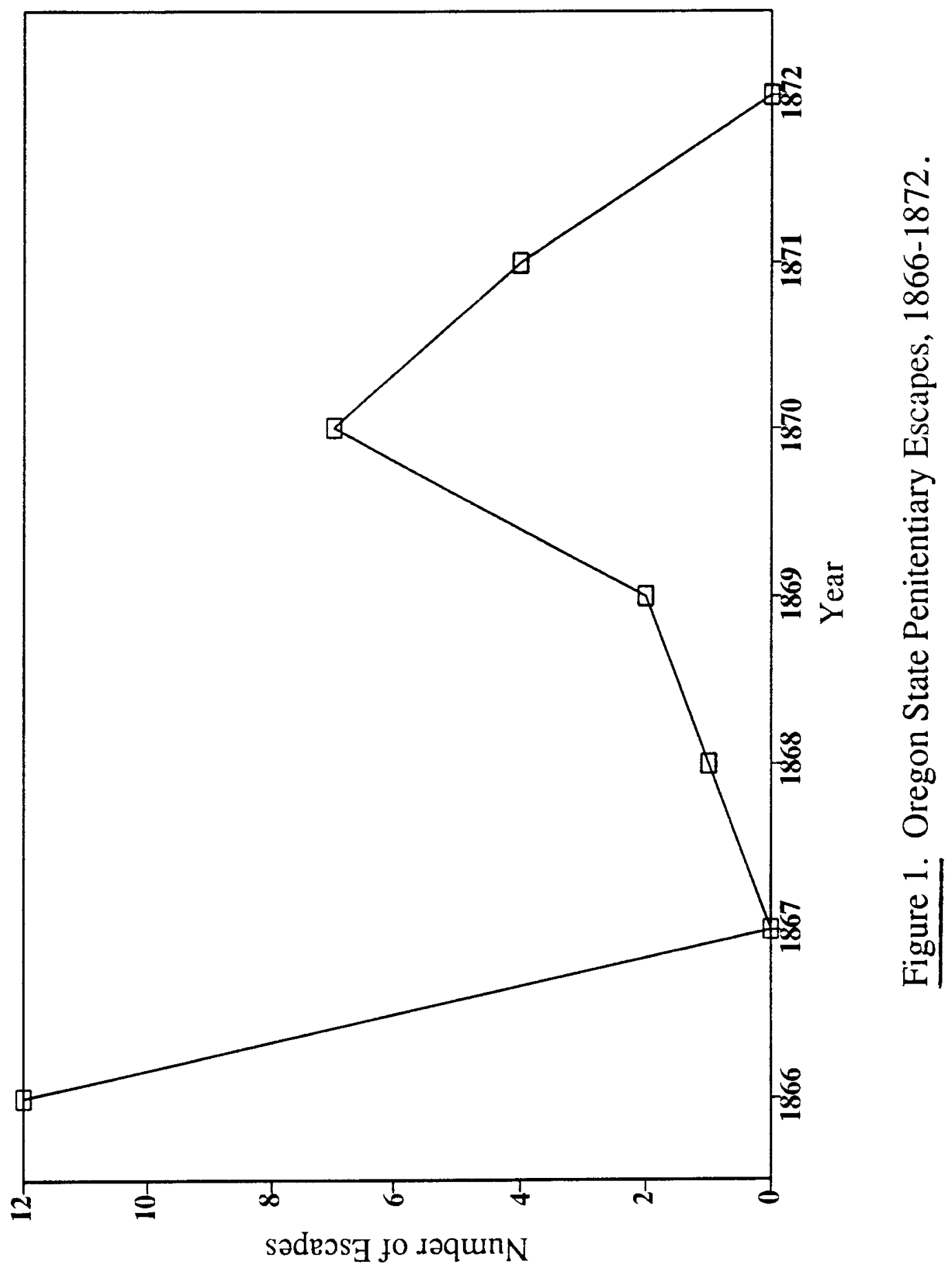


military structure temporarily brought the institution under order.

Berry's administration was wholeheartedly dedicated to "strength, constant vigilance and control of the inmates...."20 Prison rules were ardently enforced. Berry continued to use the Gardner Shackle. He also had installed in the prison armory thirteen Henry rifles, one Spencer rifle, two Sharp's rifles, a Gatling gun, twelve Army Colt pistols, and ample ammunition. "Nothing but iron and rifles hold convicts," Berry asserted, "and they combined often fail." ${ }^{\text {21 }}$ Berry, despite his faith in the military tradition, expressed doubt in the effectiveness of the disciplinary philosophy.

Just as Berry had predicted the quasi-miltary prison did, indeed, fail. Throughout his tenure ten inmates escaped never to return to the Oregon State Penitentiary. Crumbling under financial and reform pressures Major Berry was forced to relinquish control of the prison. The military structure of prisons, so prevalent throughout the nation, was slowly overwhelmed by more humane and liberal powers. The miltary doctrines of obedience, regimentation, and routine still permeated the institution. Half-hearted reform did little to change the daily routine of the prison. The Oregon State Penitentiary had fully adopted and continued to practice the employment of schedule bells, military furnishings, coarse striped uniforms, and the methodical lock-step march. Despite its brief reign as the explicit policy of the Oregon State Penitentiary, Berry's military structure would be long enduring. The precision of orders and control of routine still exists within the structure. 
As the authoritarian regime of M.P. Berry came to a close, so too did the inhumane use of the Gardner Shackle. M.P. Berry was followed in the superintendent's position by William Watkinds. Watkinds's only qualifications for the position was his scurrilous journalistic attacks on Lafayette Grover's gubernatorial opponent. Sam Clarke, owner of the Oregon Statesman, believed Watkinds's appointment corrupt and openly criticized the "spoils" within the pages of his periodical. "Watkinds," he wrote,"unquestionably belonged in the penitentiary, but not in an official capacity." On June 14, 1871, Watkinds retaliated against these written attacks and assaulted Clarke. Sliding out from a store front he "rushed up from behind, and slammed a heavy cowhide whip down..." upon Clarke's bespectacled head. Clarke staggered forward and then pulled a penknife on the superintendent. As Clarke was close to relieving Watkinds of the bullwhip, Watkinds drew a second weapon--a revolver. Sam Clarke then darted into a dry goods emporium, barely escaping the whizzing bullets from Watkinds's fire. The crowd then overwhelmed and disarmed both men.

The significance of this violent encounter is two-fold. First, it exemplifies the violence of the frontier community. While Clarke and Watkinds were supposedly model citizens and of upper social echelons they were not immune from violence in settling disputes. Secondly, their involvement in this violent episode may have had an enlightening influence on Watkinds as to the causes of violent behavior. At any rate, it shows the violent context in which Oregon's social 
institutions were set.

Syl Simpson, in a letter to Judge Matthew Deady, believed that Watkinds's encounter with Clarke "...did him good to get that little prospect of the inside of a felon's cell." That "prospect" may have been a contributing factor in Watkinds's criticism of the Oregon Boot. ${ }^{22}$ "The Oregon State Penitentiary is the only prison in the United States where this mode of murdering men by inches is practiced," Watkinds said. "It is murder," he continued," and the worst type."23 Watkinds, however, admitted that he had no penal experience. In his first biennial report in 1870 , Watkinds claimed he expected the position to "require only a portion of the officer's time; before the first quarter had closed, I found a mistake had been made in this respect...."24 The Oregon Boot was restored as a practice after Watkinds's term of office ended.

Watkinds's administration was not void of problems. During the summer of 1875 the penitentiary's shops and factories were destroyed by fire. The area was rebuilt, but with intense criticism from the legislature and the Oregon public. The criticism stemmed from an accusation of irregular expenditures made toward the end of his term of office.

Watkinds was formally investigated by the State of Oregon for misappropriation, and failure to advertise public bids. An unbiased auditor, T.F. Patton, was hired by the investigating committee to review the financial records of the prison. The superintendent refused to open his books and papers for the committee's investigation, however. When the courts forced him to reveal his 
books it was found that Watkinds, indeed, had failed to advertise bids. "No proposals whatever have been solicited by public advertisement during the past two years to supply the prison with wood. The entire amount has been let on private terms without competition. ${ }^{125}$ In addition, the supplier of wood, Samuel Bass, was overpaid by over three hundred dollars. Watkinds convinced the committee of his innocence by turning the tables on his accuser, T.F. Patton. Patton, the superintendent exposed, was indicted years earlier for impersonating an officer. Using his political power Watkinds was able to justify his financial abuse of the institution. Despite his lack of experience and the alleged financial problems, the Watkinds administration, at first, did an excellent job in maintaining daily order at the prison. He expanded the prison industries and farming programs, erected a boot and shoe factory, a flax mill, a sawmill, and planted an orchard of six hundred trees.

Toward the end of Watkinds's administration, however, the prison fell victim to administrative stagnation. Escapes, prison conditions, inmate population composition, and inconsistency in policy contributed to the prison's rapid decline. Between 1866 and 1883 there were 51 escapes, the bulk of which occurred after 1878. Between 1867 and 1876 the number of inmates received at the Oregon State Penitentiary fluctuated from thirty to sixty a year. In 1877 , however, the number rose to eighty-one and each year rose higher: 1878 to 103,1879 to 127 , and in 1880 to $171 .^{26}$ The leap in numbers incarcerated at the prison had a tremendous impact on conditions in the prison which in turn helped initiate crisis. 
While the incoming prison population increased by over six hundred percent between 1878 and 1880 the prison was not equipped to accomodate this rapid rise in population. By 1885 there were accomodations for 256 convicts while the penitentiary incarcerated 275 men. ${ }^{27}$ The bulk of this increase in population came from Multnomah County, which saw a three hundred percent increase in its contribution to the incarcerated population. There was also a dramatic change in the crimes for which these inmates were committed. Larceny proved to be the most prevalent conviction outnumbering all other convictions combined by a ratio of two to one. Between 1872 and 1885 the number of inmates convicted of larceny grew one hundred and sixty-eight percent. Physical crimes, however, underwent a much more dramatic transformation. Manslaughter convictions at the prison grew 280 percent in the same period while rape convictions increased over 600 percent and convictions for assault with a deadly weapon rose 500 percent. $^{28}$ The prison population was not only growing in numbers, but also growing more violent. The origin of the prisoners at the Oregon State Penitentiary also reveals a heightening of social and racial tension. In 1872 twenty-nine percent of the inmates incarcerated at the prison were of foreign birth. There were 23 Irishmen, 9 Germans, and 9 Chinese, and numerous other smaller nationality groups. $^{29}$ By 1885 , however, foreign-born inmates comprised thirty-five percent of the prison's population. In that year there were 25 Irishmen, 16 Germans, and 53 Chinese behind bars at the Oregon State Penitentiary. ${ }^{30}$ The prison is not a direct reflection of society, but rather its lower echelons. In a 
population overwhelmingly dominated by white Anglo-Saxon Protestants, these figures not only reveal tension inside the institution, but also the legal and economic discrimination beyond the prison's walls.

Conditions within the prison were certainly on a rapid decline. Combining prison conditions, inmate composition, and escapes with administrative inconsistency, the prison was headed down a path toward certain crisis.

Administrative inconsistency was, indeed, a key factor. On February 1, 1877, Governor Lafayette Grover resigned to take a position in the United States Senate. Secretary of State Stephen F. Chadwick assumed his position and within two weeks replaced Watkinds with the Reverend Benjamin F. Burch. Burch, however, served less than one year. The election of 1878 brought W.W. Thayer to the governorship and just as quickly as Burch was in power, he was out. Replacing Burch was one of Oregon's leading political figures, Asahel Bush. Bush was born in Westfield, Massachussetts and served there as editor of the Westfield Standard. In 1851 Bush established the Oregon Statesman. It was through this periodical that Bush espoused his conservative Democratic beliefs. He retired from journalism in 1863, but maintained an active hand in Oregon's politics. Because of his sharp criticism of the prison's management, Bush was Thayer's top candidate for reforming the institution. Bush, however, regarded his position as wholly unnecessary. He later recommended that the superintendency be "abolished and a board of inspectors substituted...." ${ }^{131}$ Bush had obtained the position through political spoils and by 1882 it was becoming painfully obvious that 
politics would spoil his tenure. In that year, Republican candidate, Z.F. Moody, was elected to the governorship. He immediately removed Bush and placed in the superintendency position Judge Julius Augustus Stratton. Stratton was a thirtyeight year old man with a stern disposition. Stratton's furrowed brow and stoic temperament, however, was tinged with keen insight and humanity.

The political shuffling of prison administrators only contributed to prison unrest and stagnation. With only four years in office the prison's superintendents of this era had no incentive to develop innovative programs. What programs were developed typically fell to the wayside as the new superintendent assumed office. Berry's use of Gatling guns is just one example. The inconsistency in administrative policy was also a contributing factor to the rapid increase in escapes. Watkinds's administration limited the number of escapes to six throughout his entire six year tenure. However, with the shuffling of Burch, Bush, and Stratton there were 34 escapes over the next six year span. By 1883 conditions within the prison, administrative stagnation, and political spoils brought the penitentiary to another critical juncture. In 1883 the prison was again consumed by a crisis which would prove pivotal in the transformation of Oregon's penal philosophy. 


\section{ENDNOTES}

1J.R. Johnson, "The Penitentiary, Our First Institution", County History, 2(1956), pp.6-10.

${ }^{2}$ The Inaugural Address of Governor L.F. Grover, 14 September 1870, (Salem: T. Patterson, State Printer,1870), p.13.

${ }^{3}$ Oregon Spectator, 20 January 1852, p.1.

4J.R. Johnson, "The Penitentiary, Our First Institution", pp.6-10.

${ }^{5}$ Oregonian, 5 November 1853, p.2.

${ }^{6}$ Ibid.

7"Oregon State Penitentiary Vignettes," unpublished, 1 May 1988.

${ }^{8}$ Ibid.

9Johnson,"The Penitentiary, Our First Institution", p.4.

${ }^{10}$ Oregonian, 27 July 1853.

${ }^{11}$ Oregon Spectator, 7 January 1854.

12"Vignettes", 1 May 1988.

${ }^{13}$ Oregonian, 30 September 1854.

${ }^{14}$ Ibid.

15"Vignettes," 1 May 1988.

${ }^{16}$ Ibid.

${ }^{17}$ Alva C.R. Shaw was nicknamed "Sheep Shaw" because he first brought sheep across the plains in 1844, see Florence Walls, "The Letters of Asahel Bush to Matthew P. Deady, 1851-1863," B.A. Thesis, Reed College, 1941.

${ }^{18}$ Johnson, "The Penitentiary, Our First Institution," p.5.

${ }^{19}$ The military structure of the penitentiary can be seen in the United States's two premier institutional prison models--the Auburn System and the Pennsylvania System. Samuel Gridley Howe, in his work, An Essay on Separate 
and Congregate Systems of Prison Discipline,(Boston,1846), remarked that "people generally admire the strict discipline, the military precision, and the instantaneous obedience to every order...." (pp.57-58) See also Gershom Powers, A Brief Account of the Construction, Management, and Discipline... of the New York State Prison at Auburn (Auburn, N.Y.: 1826) The lack of comparable literature in Oregon regarding the philosophy of punishment and incarceration in its founding era is revealing unto itself.

${ }^{20}$ Biennial Report of the Secretary of the State of Oregon, September 1870, (Salem: W.A. McPherson, State Printer, 1870), p. 45.

${ }^{21}$ Johnson, p. 6.

${ }^{22}$ Pharisee Among Philistines: The Diary of Judge Matthew P. Deady, 18711892, ed. Malcolm Clark, Jr., (Portland: Oregon Historical Society, 1975), pp. 5253.

${ }^{23}$ Report of the Superintendent and Commissioners of the Oregon State Penitentiary, 1872, (Salem: Eugene Semple, State Printer, 1872), p. 27.

${ }^{24}$ Ibid, p. 5.

${ }^{25}$ Report of the Joint Committee appointed by the Legislative Assembly to Investigate the Affairs of the Penitentiary, 1874, (Salem: Mart V. Brown, 1874), p. 11.

${ }^{26}$ Biennial Report of the Superintendent of the Penitentiary of the State of Oregon, 1880, (Salem: W.P. Keady, State Printer, 1880), p. 7.

${ }^{27}$ Biennial Report of the Superintendent of the Penitentiary of the State of Oregon, 1885, supplementary report, p. 2.

${ }^{28}$ Report of the Superintendent and Commissioners of the Oregon State Penitentiary, (Salem: Eugene Semple, 1872); Report of the Joint Committee to Investigate the Affairs of the Penitentiary,(Salem: Mart V. Brown, State Printer, 1874); Report of the Superintendent of the State Penitentiary,(Salem: Mart V. Brown, State Printer, 1878); Biennial Report of the Superintendent of the Penitentiary of the State of Oregon,(Salem: W.P. Keady, State Printer, 1880); and Biennial Report of the Superintendent of the Penitentiary of the State of Oregon, (Salem: W.H. Byars, State Printer, 1885).

${ }^{29}$ Report of the Superintendent, 1872.

${ }^{30}$ Biennial Report of the Superintendent, 1885.

${ }^{31}$ Ibid. 


\section{CHAPTER III}

\section{"SHOOT AND BE GOD DAMNED": 1883-1901}

In his memoirs, Superintendent Julius Augustus Stratton wrote that, "It is hardly possible for one of your age to realize the enormous changes that have taken place in the world during the life of the man who is now old...." ${ }^{11}$ Stratton was correct; things had indeed changed. The penitentiary was fortified and was expanding in bureaucratic power every year. One fact had not changed, however. Violence within the prison was still an ever-present danger. On July 3, 1883, a body of convicts armed with tamping irons from the foundry and primitive handfashioned knives seized Warden Collins and an overseer. The convicts held Officers Collins and Fletcher hostage and marched the two men toward the gate using them as shields. John McKern and Gid Bechamp, leaders of the revolt, demanded that Guard Wilford Stilwell open the gate. Fearing for Fletcher and Collins's lives, Stilwell opened a door leading into another part of the prison. The convicts were sufficiently fooled. As Collins was pushed through the door, he resisted, and successfully closed the door behind him. Only fourteen convicts escaped. Stilwell then emptied his rifle into the wave of escapees. Six of the convicts fell to the ground, three killed. Those convicts still at large were captured in the following weeks. ${ }^{2}$ As a result of the mass escape Superintendent Stratton 
ordered the construction of a new stockade and a new tier of cells. The old stockade had deteriorated to such a state that it was, in Stratton's words, "a constant temptation to the convicts to a general assault...." ${ }^{13}$ This crisis, though different in circumstances and magnitude from the $1866 \mathrm{crisis,}$ again stirred debate and encouraged penal change.

Stratton did indeed attempt to improve the prison's conditions. On assuming charge of the prison, he gave strict orders to suppress and stamp out the rampant opium habit within the prison. Some practices, however, remained untouched. Detective Joseph Day reported, many years later, that the water cross torture was a tactic frequently employed at the penitentiary. "The miserable victim," he said, "is stripped to the waist, was handcuffed to the wall with his arms outstretched. A powerful stream of water was then turned on him, tearing, bruising and all but drowning the poor unfortunate. No wonder they cringed and defied the guards to shoot. A merciful end from a swift-sped bullet was charitable in comparison." 4

Superintendent Stratton's tenure of office, however, is most noted for its initiation of a labor contract with Goldsmith and Loewenberg of the Northwest Foundry Corporation. The contract established a stove factory in the prison compound, employed prison labor, and paid the convicts fifty cents a day. ${ }^{5}$ "The results of the employment of the convicts under the existing contract is so far encouraging," the superintendent wrote in 1884, "It accustoms them to habits of industry, without which I think, any efforts at reform are likely to prove futile."6 
Stratton, however, was replaced in 1884 by George Collins. With the new governor came a new prison superintendent. Collins's term of office was undistinguished and uneventful.

Collins's entrance into prison administration began with his expertise in brickmaking. Born in Eastport, Maine in 1834 George Collins was put to work early in the local brickyard to help support his family. After the conclusion of the Civil War Collins moved west and settled in Salem, Oregon. In 1868 Collins and his brickmaking partner were contracted to build the Ladd and Bush Bank. By 1870 , with a shift in superintendents at the prison, Collins was hired as warden of convict labor at the penitentiary. Having forged valuable political ties as warden, Collins resigned and re-entered private business. Two years later he secured a contract from Marion County to manufacture over one million bricks for the County Courthouse. He later served as Superintendent of Construction of the Oregon State House and leased penitentiary bricks and convict labor to complete the project. It was obvious that the prison was a profitable ally and tool for the brickmaker. In 1882, however, Superintendent Stratton furthered Collins's career by offering him the position of First Warden of the State Penitentiary. Collins, naturally, accepted the offer and only two years later succeeded Stratton as superintendent. In 1887 Collins resigned to return to private business. ${ }^{7}$

His tenure as superintendent, though marked by no significant uprisings or political crises, gives evidence of the financial power the prison offered.(See Figure 2.) His alliance with the prison, and therefore the State, profited George 


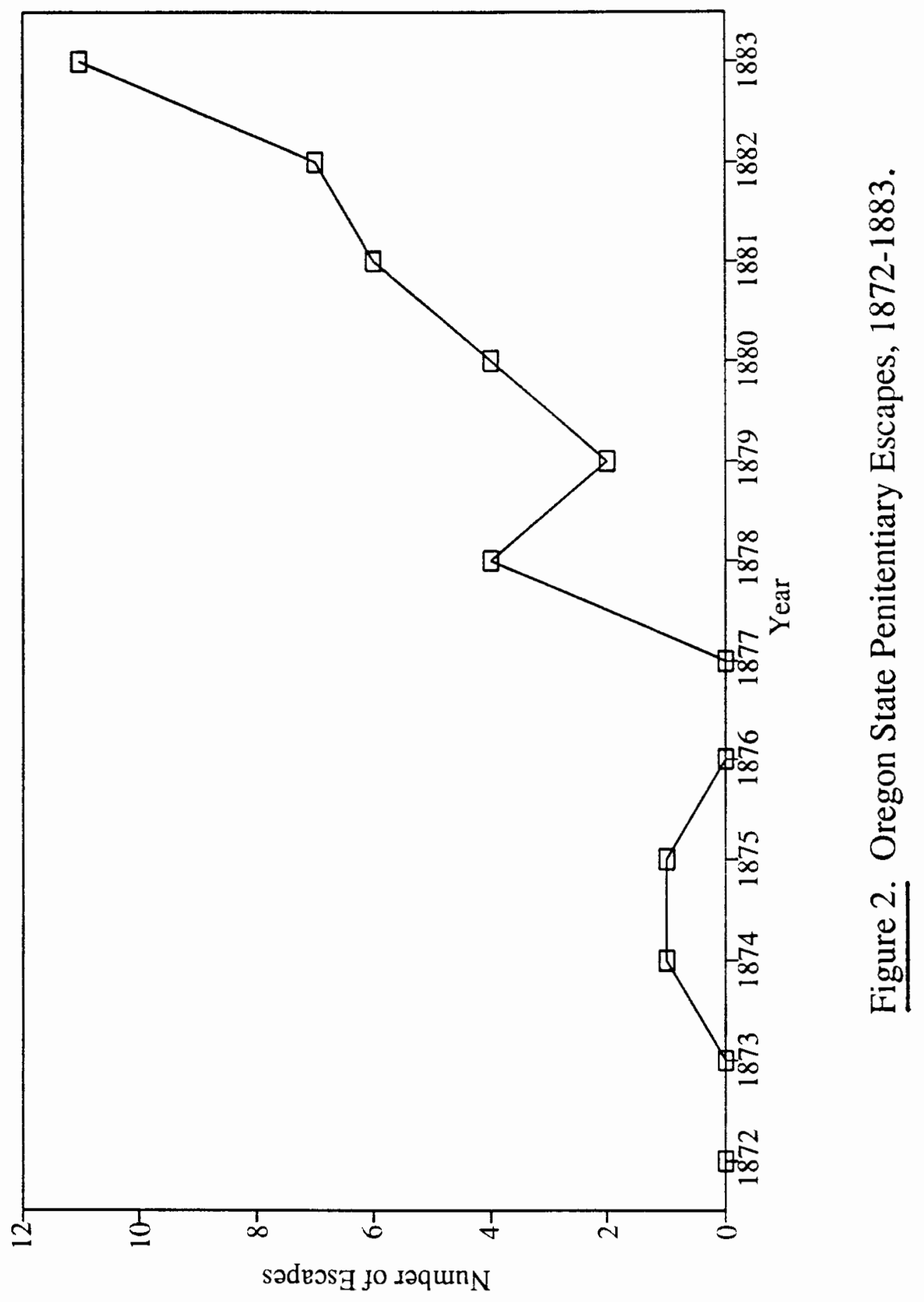


Collins immensely. It furthered both his business career and his term of "public service." In this case Collins's public interest was for private interest. Popular public interest was served when Sylvester Pennoyer, a Democratic-Populist, was inaugurated as governor on January 12,1887 . Pennoyer's administration was based on political reform and, as we would now define it, racism. He pardoned inmates at the penitentiary in unprecedented numbers. "Every change of governors," an inmate wrote, "was looked forward to with much speculation and hope, but they brought no relief, until Governor Pennoyer was elected." ${ }^{8}$ This reform principle, however, was not extended to the hardest of the prison's inmates. These inmates, now taunted with the hope of freedom, fell back into their slavish existence with greater fear, frustration, and indignation. The struggle between the staff and inmates would be further magnified by the apparent racism exemplified by Pennoyer. He was Oregon's foremost advocate for Asian deportation and exclusion. The population of the prison was not drawn randomly from the ranks of society, but is a mirror of that society's lower echelons. The Oregon State Penitentiary was no exception. Among those lower echelons were the struggling immigrant groups against whom Pennoyer discriminated.

During Pennoyer's administration 26 to 49 percent of the prison population was foreign-born. In 1889 the number of foreign born inmates peaked with the Irish and Chinese comprising the bulk of that population. In that year there were 27 Irish inmates and 52 Chinese. ${ }^{9}$

Just as the pressures of foreigners in Oregon's "free" community brought 
about tension, the growing numbers of foreign-born inmates undoubtedly heightened xenophobic feelings among the prison's predominantly white population. This large foreign inmate population is a direct reflection of declining conditions beyond the walls of the penitentiary. Typically among the lower echelons economically, foreign-born Oregon residents were frequent scapegoats for economic hardtimes. The inmates too were engaged in a delicate and precarious struggle for existence against seemingly insurmountable forces.

In 1893 Pennoyer used the prison as a tool for his racist agenda. He helped convince the state legislature to not renew the prison contract with Goldsmith and Loewenberg. Instead, Pennoyer suggested that the state build a prison jute mill. Throughout the west only Chinese immigrants produced the jute (burlap) bags. Therefore, Pennoyer argued, a jute mill at the prison could be operated without competing with free white labor. This policy reflects Pennoyer's focus on financial self-sufficiency rather than reform and his use of the prison as a tool for his openly racist platform. ${ }^{10}$ Financial pressures, largely as a result of a recent nationwide depression, crippled Pennoyer's efforts and the jute mill plan was abandoned.

Pennoyer's plan for penal reform included a new superintendent, George S. Downing. Downing served the entire eight years of Pennoyer's governorship. During those eight years, he maintained strict discipline and brutally employed the convicts under him. One desperate convict, Frank Howard, refused to work, writhing in pain from a self-amputated arm. He told reporters that he would cut 
off his right hand before he would perform manual labor at the prison again. Superintendent Downing quickly intervened and ordered the convict to work and threatened the deranged man with the tread wheel. The tread wheel was a wheel turned by the flowing water of Mill Creek. The convict who did not keep step with the turning wheel, fell to its passing tread and was dragged under and drowned. Downing ordered Howard to walk the wheel twelve hours a day or work. ${ }^{11}$

Another convict, William Mansfield, complained of work in the moulding room. Telling his guards that he felt ill, Mansfield was ushered to the infirmary where hospital steward W.W. Saunders gave the diagnosis that Mansfield was completely healthy. Mansfield, however, was adamant about not returning to work. He swore obscenities at Warden McKinnon who attempted to subdue Mansfield with handcuffs. The convict fled, defied the guards's orders, but returned to face his captors. Mansfield took off his cadet coat and cap, threw them on the floor and said, "shoot and be God damned."12 Warden McKinnon gave the orders and guard John Whitley shot. By 9:30 of that same morning, William Mansfield lay dead in a pool of blood. The authorities later claimed that Mansfield possessed a dagger, but never drew the weapon in confrontation.

While external forces were stable--Pennoyer was re-elected in 1891-internal forces were growing to explosive proportions. The prison population was growing rapidly. Not only was inmate discontent a problem, but the prison staff also became more disenchanted. The handling of a larger inmate population 
without a staff increase must have been troublesome. One example of staff discontent is that of J.L. Parrish. "Oregon is the only state in the Union that has not a paid Chaplain to conduct services in her penitentiary," Reverend Parrish said. "I am not a beggar," he continued, "but considering my limited circumstances, I believe it a duty to myself to ask our present legislature to consider my services and make me at least a small appropriation."13 Parrish, however, grasped many convict's hands in his twenty-seven years of visiting the inmates. In his later years his visits became less frequent, and in May of 1895, Parrish passed away. George Downing left the superintendent position that same year. The death of J.L. Parrish and the end of Downing's superintendency marked the end of another cycle of crisis, reform, and decline.

In this second cycle conditions temporarily improved, but then reverted. Commitments to the institution decreased between 1883 and 1886 helping to alleviate the overcrowding and internal tension. The number of foreign-born inmates increased from thirty percent in 1887 to forty-nine percent in 1889 and back down to thirty percent by $1893 .{ }^{14}$ Tensions remained high. The number of convicts over that period rose from an average of 306 in 1889 to 379 in $1894 .^{15}$ After Governor Pennoyer's term of office ended the number of foreign inmates dropped from thirty percent in 1895 , to twenty-five percent in 1897 , and to seventeen percent at the turn of the century. In a prison population with a high concentration of foreign-born inmates racial and nativist tensions run high due to the proximity of the inmates and the prevailing racial and bigoted sentiment of the 
period. The decline in the foreign-born population, however, did not resolve the tension. A low foreign-born population is frequently subject to internal discrimination because the foreigners are seen as the scapegoats for the economic and social problems which brought the white inmates to the prison. Racial tension in the prison is a magnification of the same tensions outside the prison's walls. In Oregon, during this period, racial tension ran high--especially during the administration of Pennoyer. Despite a decline in nativist tensions, religious tensions still existed. In 1895 Catholic inmates outnumbered Protestants 342 to $281 .^{16}$

Tensions in the prison were further exacerbated by a shift in convictions. Between 1887 and 1893 larceny steadily rose in percentage of inmate convictions while other crimes declined. But after 1893 things changed. Decreasing from seventy-one percent of total convictions in 1893 larceny dropped to fifty-two percent in 1895, forty-one percent in 1897 , and thirty-two percent in 1899 . Likewise there was an increase in rape and second-degree murder convictions over that same period. Sensing an infusion of hardcore criminals the prison administration reduced the number of trusties available for outside work from 348 to $177 .^{17}$

The situation within the prison began to reach epidemic conditions. In 1897 alone there were over 2000 reported hospitalizations from the prison. The Biennial Report of 1897 recorded over 248 cases of malarial fever, 202 incidences of chronic diarrhea, 181 cases of dyspepsia, 153 cases of rheumatism, and 152 
hospitalizations for acute bronchial catarrh. In addition there were 24 cases of wounds. Whether these were work-related injuries, staff beatings, or inmate fighting wounds cannot be determined. Regardless, conditions within the prison remained deplorable.

The prison was further troubled by a failing prison industry. The onset of the nation's worst economic depression in 1893 set the prison reeling. Governor Pennoyer's plans to construct a jute mill were abandoned and the prison's recently purchased foundry struggled. In Governor Lord's farewell address of 1899 , he reported: "Thus far, the result of working convicts in any enterprise, either by the state or by leasing them to private parties, has not proven entirely satisfactory or very remunerative."18

The combination of foreign inmates and violent offenders, coupled with poor prison conditions, a failing prison industry, and brutal discipline, led the penitentiary toward an inevitable crisis. This crisis exploded in 1902 with the dramatic escape of inmates Harry Tracy and David Merrill. 


\section{ENDNOTES}

${ }^{1}$ Julius Augustus Stratton, "Autobiographical Sketch of Julius Augustus Stratton," Oregon Historical Society, Portland, 1.

${ }^{2}$ Oregonian, 4 July 1883 , p. 3.

${ }^{3}$ Biennial Report of the Superintendent of the Penitentiary of the State of Oregon, 1885, (Salem: W.H. Byars, State Printer, 1885), p. 8.

${ }^{4}$ Oregonian, 15 August 1925, p. 2.

5"Vignettes", 1 May 1988.

${ }^{6}$ Biennial Report, 1885, p. 5.

${ }^{7}$ Personal papers of Eleanor Miller, Salem, Oregon.

${ }^{8}$ Lend A Hand, Oregon State Penitentiary Newspaper, August 1913, p. 2.

${ }^{9}$ Biennial Report of the Superintendent of the Penitentiary of the State of Oregon, 1889.

${ }^{10}$ Ward McAfee, "The Formation of Prison-Management Philosophy in Oregon, 1843-1915", Oregon Historical Quarterly, Fall 1990, vol.91, no. 3, p. 260.

${ }^{11}$ Capitol Journal, 2 February 1889.

${ }^{12}$ Oregonian, 24 June 1888, p. 2.

${ }^{13}$ Biennial Report of the Superintendent of the Penitentiary of the State of Oregon, 1887, (Salem: W.H. Byars, State Printer, 1887), p. 31.

${ }^{14}$ Biennial Report of the Superintendent of the Penitentiary of the State of Oregon, 1887, (Salem: W.H. Byars, State Printer, 1887), p. 21.; Biennial Report of the Superintendent of Penitentiary of the State of Oregon, (Salem: Frank C. Baker, State Printer, 1889), p. 32.; Biennial Reporrt of the Superintendent of Penitentiary of the State of Oregon, (Salem: Frank C. Baker, State Printer, 1893), pp. 46-47.

${ }^{15}$ Biennial Report of the Superintendent of Penitentiary of the State of Oregon, (Salem: Frank C. Baker, State Printer, 1895), p. 60. 
${ }^{16}$ Biennial Report of the Superintendent of Penitentiary of the State of Oregon, 1889; Biennial Report of the Superintendent of Penitentiary of the State of Oregon, 1891; Biennial Report of the Superintendent of Penitentiary of the State of Oregon, 1893; Biennial Report of the Oregon State Penitentiary to William P. Lord, Governor of Oregon, by A.N. Gilbert, Superintendent, 1897, (Salem: W.H. Leeds, State Printer, 1897); Biennial Report of the State Penitentiary, (Salem: W.H. Leeds, State Printer, 1899).

${ }^{17}$ Biennial Report of the State Penitentiary, 1899.

${ }^{18}$ Ward McAfee, p. 262. 


\section{CHAPTER IV}

\section{"TO HATCH TROUBLE": 1902-1914}

The political shuffling and spoils of the late nineteenth century did nothing to improve the quality of life or conditions within the prison, nor did it insure the effectiveness of security. In fact, the political shuffling had no positive influence on the structure of the institution. The superintendent, whether Republican or Democrat, was almost always more concerned with his preservation of power than in anything having to do with the institution itself. Measures taken in regard to the institution were acts to bolster reputation, not acts of reform. The political shuffling and spoils in Oregon, however, did agitate the crisis within the prison's walls. First, with short-term superintendents no platform of genuine reform was allowed to be introduced or allowed to follow its natural course. Stagnation in policy was the natural consequence of this political shuffling. Secondly, inmates conscious of "softening tendencies" and more tolerant and progressive public opinion tended to believe that the incoming governor and superintendent would be more lenient on his parole plea. This, however, was rarely the case. The unrealized expectations of these inmates fostered a violent frustration and resentment toward the staff and administration. The hostility of inmates toward the staff was then met with heightened fear and force by the staff. Again, this is 
the paradox of the penitentiary.

Conscious of public opinion and victims of prison abuse, inmates Harry Tracy and David Merrill would launch the Oregon State Penitentiary into another cycle of violence, reform, and stagnation. This crisis, stirred by the same factors that gave birth to the events in 1866 and 1883 , was far different from the preceding crises in that this event captured the imagination of thousands in Oregon, Washington, and various parts of the nation. The front page of the local newspapers focused on the Tracy-Merrill affair for weeks.

One inadequacy within the prison's policies was the obvious neglect to separate or isolate hardened criminals from one another. Partners in crime often became cellmates and co-workers inside the prison. This failure to address each criminal in an individual fashion allowed contempt to breed within the institution. Inmates plotted revenge and planned their escapes. Throughout the spring of 1902, two of the Northwest's most notorious criminals plotted their escape, and by the summer of the same year they were ready to place their plan into effect.

Harry Tracy and David Merrill were two of the most cunning and quickwitted criminals to set foot in the Oregon State Penitentiary. The course of their lives before entering the prison's gates and walls is a tragic story of lost hope, penal failure, and crime. Harry Tracy was born in 1871 in Duchess County near Newburg, New York. ${ }^{1}$ Superintendent Lee in later years said of him, "In conversation with him he was very direct, and although devoid of much education he had good use of language." 2 But trouble in New York forced Tracy westward 
to escape his bad reputation. En route west, however, he incurred further problems and spent nine months in the penitentiary in Little Rock, Arkansas. He was a man of medium build, "...close-mouthed, pleasant with men or women for whom he felt no apprehension, inclined to boyish outbursts of laughter and gaiety."3 But Tracy's gaiety often turned sour. In 1897 , he was sentenced to one year in the Utah State Penitentiary for burglary. Tracy's early errors had a twofold effect. First, the mistakes he made cost him his freedom, but also hardened him and forged him into a reckless, fearless criminal. Secondly, he learned from these early mistakes. He was not a nickel and dime thief anymore. He was not a naive petty criminal, but a professional. After only two months in the Utah State Penitentiary, Harry Tracy escaped. Superintendent Lee later claimed that in all his years he had "...not yet met a man with so many strong points to qualify him for a successful criminal career as Harry Tracy. His quickness of apprehension was Napoleonic. He had a nerve of steel. With him the taking of human life was a question of expediency only. His reckless, dare-devil exploits and hairbreadth escapes, were to him, diversion."4

Following his escape from the Utah State Penitentiary, he had obviously built up a strong enough reputation and following to warrant his title as leader in the notorious "Hole in the Wall" and "Powder Springs" outlaw gangs. But with his criminally admired reputation came his recognition among western law enforcement officers. He was captured in Colorado and convicted at Aspen. Again, Harry Tracy escaped, "...beating three guards into insensibility and binding 
and gagging the sheriff." He was recaptured and, remarkably, escaped a third time. $^{5}$

Tracy moved north into Montana where he held up the Exchange Saloon, stealing among other things the bartender's watch. A young Montanan, D.J. Kelly, was arrested for the Exchange Saloon burglary. Uncharacteristically, however, Tracy sent a confession to local authorities to absolve Kelly of the crime for which he himself had committed. "If that man is not out," Tracy wrote, "write and I will give satisfactory description of the crime...." ${ }^{\prime 6}$ By this time, however, Tracy was long gone. From Montana Tracy pushed westward to Seattle, where he made contacts that later proved critical to his refuge from the prison posse. Seattle authorities soon heard rumors of Tracy's arrival and so the young bandit moved south to Tacoma and then into Portland.

In 1898, Tracy and a Vancouver, Washington native, David Merrill, linked up to engage in hop yard robberies. Tracy was subsequently introduced to Merrill's sister, Mollie, whom he later courted and married. Merrill was a "...willing follower of his more crafty and resourceful brother-in-law."7 Tracy and Merrill's headquarters were at 207 Market Street in Portland. From this point they conducted a vast array of crimes and highway robberies. Tracy and Merrill justified their "night work" by telling their neighbors and landlord that they were engineers on the Puget Sound night run. Their criminal plans were laid bare in 1898 when the men were captured and convicted of highway robbery. Merrill was sentenced to thirteen years and Tracy, because of his leadership role and past 
record, was sentenced to twenty years.

On March 22, 1899, Tracy and Merill entered the Oregon State

Penitentiary. They were quickly assigned duty in the moulding room, the same room that a decade earlier William Mansfield refused to work in and died refusing. Labor, the officials thought, was the only way of reforming these criminals. Tracy and Merrill spent the next three years and seventy-seven days behind the massive grey walls of Salem's prison. As cellmates and co-workers, Tracy and Merrill were afforded great opportunities. Their conduct as prisoners was bad. The two young criminals sat in their cell and fostered plans of revenge and escape. In 1899, they forged an intricate plan of escape, but their plans were tipped off by a fellow inmate and both were subsequently restrained. "Profiting by experience, they took no one into their confidence again, but made their next venture alone. ${ }^{18}$ The turn of the century passed and Tracy and Merrill grew more restless in their confines. With each passing day, they grew more and more bitter. They refused to work and were punished. Guards Frank Ferrell and "Berry" Tiffany disciplined them with a firm hand. Tracy showed brief evidence of reform as he attempted to educate himself as to Oregon history and geography. He studied maps of Oregon and thoroughly familiarized himself with roads, trains, and towns all on the route over which he afterward passed.

Tracy's reputation was growing nationwide. He was a notorious criminal leader and renowned escape artist. Yet, officials at the Oregon State Penitentiary did not separate him from his partner in crime, David Merrill. Nor did they 
present an individually-tailored plan of discipline for him.

Superintendent J.D. Lee, a political appointee of Governor T.T. Geer, served a placid term with the exception of the Tracy-Merrill affair. The 1900 legislature appropriated $\$ 15,000$ to the Lee administration for improvements at the penitentiary. Lee allocated the funds for the construction of a new wing in which was located a new dining room, commissary department, hospital, bathroom, and heating plant. Coupled with legislative funding the prison became more self-supporting.

On June 9, 1902, the prison's serenity came to an abrupt halt. At seven o'clock that morning all one hundred and fifty-nine convicts filed in for work at the foundry. Suddenly, inmates Harry Tracy and David Merrill seized hidden arms and shot the foundry guard Frank Bonham Ferrell. During the previous night Harry Wright, an ex-convict, scaled the prison's walls and stashed two rifles and a good supply of ammunition in the moulding room piles. As was customary among the prison shops, none of the guards were armed with anything but canes with which they were to keep the men in line. When guards Frank Girard and John Stapleton heard the gunfire and saw their friend and fellow guard dead they began to flee to the nickel room adjoining the work space. Tracy ordered the other prisoners to the opposite side, fired some shots at the guards in post number one and then fell into pursuit of guards Girard and Stapleton. Linn County inmate Frank Ingram begged Tracy and Merrill to spare the two guards's lives and attempted to impair their pursuit. Ingram was shot in the leg by the 
desperate bandits. Tracy and Merrill fled through the front shop and carpenter shop where they acquired a ladder. Once outside the two men exchanged shots with the two guards on the east wall, guards Duncan Ross and Bailey T. "Berry" Tiffany. All shots went astray. The inmates then shot at the northwest guard tower, killing guard S.R. Thurston Jones. Tiffany and Ross then chased the fleeing convicts around a corner when they were suddenly confronted face-to-face with the notorious criminals. Tracy ordered Tiffany and Ross to drop their weapons, and the guards reluctantly obliged. The foursome then marched about one hundred yards when they were suddenly besieged by gunfire from the wall. Agitated by the gunfire, Tracy and Merill returned shots, killing Tiffany and wounding Ross. Tracy and Merrill scaled the walls and fled to the forests of south Salem.

Within a five minute span the prison lost three officers: Ferrell, Jones, and Tiffany. Ingram, the wounded prisoner, was hastily ushered to the hospital where doctors amputated his leg to save his life. Ingram was subsequently pardoned and released in recognition of his valorous acts during the escape. The serenity had been broken, however. The tragic event marked, or rather triggered, a new era in Oregon's penal policy. ${ }^{9}$

The tragedy, however, was not quite over. The elusive and cunning Tracy was still at large with his faithful ally Merrill. The two men fled to the thick woods of south Salem. Superintendent Lee was at his cottage when he heard the exchanges of gunfire. He immediately went to the prison and stationed his son 
and assistant warden in the posts of the fallen guards. It was Lee's supposition that since Tracy and Merrill were prominently identified with a ring of criminals throughout the Northwest, that they would easily receive assistance and thus make their capture more difficult. Lee was intent upon capturing the two outlaws. A reward of $\$ 1,500$ was posted for their capture and return, dead or alive. Several days later the bounty would be doubled. Lee organized armed posses and set out in pursuit now almost an hour and a half after the outbreak. Lee called for assistance from the asylum, city and county law enforcement officers, and the state militia. Salem Chief of Police Gibson, Marion County Sheriff Frank Durbin, and Sheriff-elect Colbath were soon on the scene to aid in the pursuit. Governor Geer, having been notified of the escape, called out the Oregon National Guard companies of Salem and Woodburn. Bridges and ferries over the Santiam and Willamette Rivers were closed. Superintendent Catron of the Washington State Penitentiary in Walla Walla was wired to request the use of the prison's bloodhounds. Guard M.E. Carson arrived from Walla Walla with the dogs by noon of the day after the outbreak. Tracy and Merrill were spotted by their pursuers in a wheat field near Gervais, but the over-cautious militiamen were too slow to move in and the two escapees slipped out of sight once more. Tracy and Merrill had seen their pursuers as well. Merrill wanted to shoot Sheriff Durbin, but Tracy prudently convinced him to refrain from shooting. The two outlaws coursed their way northward through the thick brush, robbing local people and merchants enroute. They robbed J.W. Roberts of clothing, secured overalls from 
Roy Ohmart, an overcoat from expressman William F. Welch, and stole horses from saloon keeper Felix Labranch. The people in the vicinity of prison were alarmed. The escape had now captured statewide attention. That night they slept uneasily under the stars. The next morning, however, they invaded the home of August King and demanded to be served breakfast. The older man obliged. That afternoon they backtracked and ambushed the lead posse riders, Dr. White and Mr. Dupuis, and stole their clothing and money. On the following morning Tracy and Merrill returned for breakfast at August King's place. It "...was not only a compliment to the wood-chopper's culinary accomplishments, but was a source of almost inexpressible surprise to the baffled crowd."10 Tracy and Merrill were polite and offered to pay for the "grub." When King explained the odd events to the posse and how the two had offered to pay, Dr. White of the posse groaned, "Yes, out of my pocketbook, I suppose."11 The bandits, however, never returned for a third breakfast. The two men moved north paralleling the Southern Pacific Railroad, east through Monitor, and then north across the Pudding, Butte, and Rock creeks to Needy, Oregon. Outside of Needy they ate dinner at the farm of E.D. Graves.

Chafing at delays and disorganization in the man-hunt, Charles Ferrell of Reno, Nevada, brother of the slain guard, urged the posse on. James and George Ferrell later joined in the pursuit of the outlaws. Tracy and Merrill were still too elusive. From Needy they proceeded to New Era where they stole horses from Will G. Randall's farm about five miles south of Oregon City. Tracy and Merrill 
then advanced rapidly through Oregon City, Milwaukie, Sellwood, and east Portland. The posse's failure to quickly recapture Tracy and Merrill aroused intense public criticism. Superintendent Lee reported to the Oregonian that "...I will never rest until I run the fiends down."12 Five days after the initial outbreak the militia retired from the chase, and yet the outlaws were still at large. The affair covered the front pages of every Oregon newspaper. The dilemma in prison philosophy pitting the rehabilitative model against the disciplinary model rose again. The pursuit of Tracy and Merrill turned into a circus of bumbling clowns (the posse) and daredevil escape artists (Tracy and Merrill). In an Oregonian editorial it was written, "Tracy and Merrill have one great advantage over their pursuers, they don't have to stop every few minutes to have their pictures taken." ${ }^{13}$

The two outlaws looked to familiar ground in Washington for refuge. They commandeered a boat across the Columbia River and rested in an area west of Brush Prairie. Meanwhile the bungling posse incurred further criticism. Independent man-hunters William E. Morris and L.D. Seal of Vancouver were mistken by the posse for Tracy and Merrill. Morris was shot and, like Ingram, was forced to have his leg amputated to save his life. The press rankled at the delays, "Unless the officers of the law are willing to incur some risk and danger, it is not likely they will ever catch or kill the escaped convicts and murderers.."14 Tracy and Merrill slowly moved north to Kelso, Washington. Having read of Morris's shooting, the two men laughed, and learned from their pursuers mistakes. 
Enroute, Tracy and Merrill told local people they crossed that they were hunting down the murderous escaped convicts from the Oregon State Penitentiary. The bungling continued much to the amusement of Tracy and Merrill. Whatcom, Washington police killed an innocent Godfrey R. Campbell of Black River Falls, Washington, believing him to be the elusive Harry Tracy.

Towards the end of June, Tracy and Merrill began quarreling. To settle their dispute the two outlaws decided to fight it out. "They were to walk a certain distance apart and then turn and fire. Tracy did not keep faith with Merrill and turning, shot and killed him as he was walking away."15 Tracy later attempted to justify his action by claiming that "...he intended to shoot me. The day before the quarrel we found a newspaper which contained an account of our escape and the pursuit. That accout gave Merrill equal credit with myself for the deeds which I alone committed...."16 This confession reveals the true intent of Tracy in the Exchange Saloon burglary confession and paints Tracy as an egomaniacal criminal. In mid-July a Lewis County, Washington, woman discovered the remains of David Merrill and brought the then unrecognizable body in an airtight casket to the officials at the prison. David Merrill was buried in the prison cemetery in an unmarked grave. Merrill had simply served his purpose, the initial escape. Once beyond the prison David Merrill was useless and so Tracy eliminated his slower partner and relieved himself of any hindrance.

Again, Tracy commandeered a boat and chugged past McNeil Island, Tacoma, and Seattle. He forced a landing at Meadow Point, two miles north of 
Ballard, then a Seattle suburb. For the next few weeks Harry Tracy darted back and forth across the Olympic Peninsula, eluding the posse, befriending locals, and killing Sheriffs Charles Raymond and Jack Williams. In a shoot-out at the Van Horn residence, Tracy killed again. This time he murdered policeman E.E. Breese and a miner, Neil Rawley. The death of three western Washington law enforcement officers appalled the public. ${ }^{17}$

Tracy then set out to return east. He had come west to avoid his reputation and had placed his feet in the Pacific Ocean, but he did not outrun his reputation, he lived it out. Now he started for the east. But on August 5, 1902, Attorney Maurice Smith, Constable C.S. Straub, Dr. C.E. Langer, J.J. Morrison, and Frank Lillengren tracked Tracy down and wounded him in Lincoln County, Washington. "Finally cornered in eastern Washington, he was wounded, but escaped into a wheat field, where after vain attempts to bandage his wound so that he might proceed, and knowing that capture was certain, he fired a revolver bullet into his brain...."18 Great gouts of blood spurted from his head, drenching his stolen clothing, and dripping into tiny puddles upon the matted wheat. Harry Tracy was finally dead. Tracy's August 5 suicide ended two months of Northwest terror during which he had killed eight men in his escape and subsequent chase.

On August 9, 1902, the corpse of Harry Tracy was returned to the Oregon State Penitentiary. There was no ceremony, priest, or prayer as his body was laid to rest in Potter's Field. Superintendent Lee eulogized a bit in his 1902 Biennial

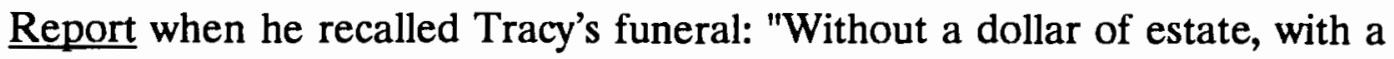


reputation for crime only, while yet a young man, his sun set in darkness and his remains lie unhonored in a prison cemetery." 19

What helped breed the Tracy-Merrill affair, however, were two ingredients: stagnation and political shuffling. The political shuffling began in January 1895 when William Paine Lord was inaugurated as the ninth governor of the State of Oregon. His 1894 election ended the Democratic governorship of Sylvester Pennoyer, and thereby gave him the power to wipe Oregon's institutional slate clean and appoint his own friends, confidants, and political allies.

By March of 1895, Pennoyer's penitentiary crony, George S. Downing, was gone, replaced by Lord's Republican ally, A.N. Gilbert. Gilbert assumed his duties as superintendent of the Oregon State Penitentiary on March 11, 1895. Under the existing state constitution, the governor of Oregon also served as the prison inspector. During a visit to the prison, Governor Lord attempted to fulfill his prison responsibilities and began interviewing inmates throughout the prison. In each case, the convict told Governor Lord the shocking details of his alleged crime and subsequent incarceration. Each inmate ended his tragic tale with a confession of innocence. Only one inmate, however, stood strong and admitted his guilt. Upon completion of his investigation and tour of the institution, Governor Lord returned to his office and told his secretary, "I have found a bad condition at the penitentiary. All of the men confined there are innocent save one. Please fill out a pardon for that young man. He will certainly exert an evil influence over the innocent men."20 
This anecdote not only points to Governor Lord's satiric wit, but to his understanding of a complex and delicate issue. Lord, however, was not willing to confront the prison situation with a plan of inmate rehabilitation. Institutional perpetuation and preservation dominated the preceding prison administration. Governor Lord and Superintendent Gilbert were determined to break this mold, however, and cast Oregon's penal system into a modern enlightened state.

Lord's enlightened state, however, was not based on rehabilitation. In keeping with the Republican party, Lord stressed prison discipline and security. He further emphasized economic management of the institution in order to relieve Oregon's taxpayers from the "burden imposed by misfits and failures."21

One especially vocal convict, Joseph "Bunko" Kelley, summarized inmate discontent with the Republican party's disciplinary platform when he lambasted the previous Republican gubernatorial administration. "I do not want to run down all Republicans," Kelley said, "for there are just as good men in the Republican party as there are among Democrats...But, reader, you have never before had the facts of the Oregon penitentiary as it was run under the Republican governors, Lord and Geer."22 Lord and Gilbert, however, were dedicated to prison "reform."

It took only a "cursory view" of the prison and the prison grounds to convince Superintendent Gilbert that there were great obstacles ahead for their plan of reformation and renovation. ${ }^{23}$ The structure had not been significantly improved since its completion in 1871. Certainly, new walls and buildings were 
added, but the existing structures were not properly repaired or maintained. The fourth tier of the prison's north wing had deteriorated to such an extent that the level was virtually "useless for the confinement of any class of prisoners. ${ }^{\text {"24 }}$ The decaying wooden structures were quickly seen by the Gilbert administration as fire hazards. Gilbert stated in his Biennial Report of 1897 that, "Were a fire started in this basement, the prison would go like a tinderbox, and every prisoner would be cremated."25 While that might solve the prison's overcrowding problems, every administrator since that first fateful fire of 1846 was concerned with the institution going up in flames.

After fire, fear of disease ranked as the principle concern of the superintendent. Typho-malarial diseases had consumed dozens of inmates at the prison since its creation in 1866. The prison's proximity to Mill Creek stood as the primary cause of this problem. Gilbert quickly assessed the situation and judged that the trouble rested in the "imperfect drainage" of the institution. ${ }^{26}$

Governor Lord and Superintendent Gilbert, however, were dedicated to improving the institution's conditions. If not for the sake of the prisoners, then for the sake of their political reputations. The process of reform was to begin. Gilbert never saw the prison as a reformatory, but rather an object to be reformed. To reform the prison was to reform one's political reputation and power.

Their intentions, however, quickly crumbled as the financial reality of the situation came to the fore. Gilbert struggled to maintain within the budgetary 
limits set by the state assembly. By an act of the legislature of 1895 , the governor was authorized to contract and lease the labor of the inmates in order to assist in the funding of the institution. Gilbert, without hesitation, saw the contract and lease system as the best plan for both the state and the convicts. The inmate's labor would provide much needed income for the state and serve as therapeutic reform. Idleness among the inmates, he thought, was disastrous to the prisoner's morale and to the public's welfare.

In his Biennial Report of 1897 , Gilbert asserted that inadequate funding and misappropriation in the past contributed to the prison's poor conditions. ${ }^{27}$ Though Lord and Gilbert held the power to alter the course of the prison's history through reform and rehabilitation, they failed to produce any significant transformations.

Transformations at the penitentiary, however, have traditionally been elusive. The prison's history is a phenomenon of change without change. Gilbert's administration, like every administration before and after, faced the same political and financial problems and the same violent crises. Gilbert's administration was not unusual. He tried reform, enforced discipline, and fortified the structure. And to a small degree he was successful. But the penitentiary did not change. The faces were different, the penal techniques conformed generally to contemporary penal thought, but crisis still existed. Each generation of superintendents faced the same problems. Gilbert's failure rests not in the measures taken, but in the absence of a clearly defined and maintained purpose. 
The policy of the party in power always disintegrated with the inauguration of a new governor or the appointment of a new superintendent. There was simply no consistent penal philosophy in application at the prison. Consequently, the prison was continually in a process of stagnation and decline. Inconsistency plagued the institution. Decline in Gilbert's administration is, at first, not apparent.

No bricks were made in the prison yard during his entire administration. Prior to that the brick industry was the principle funding source for the institution. Gilbert and Lord's vision as prison reformers may have been well-intended, but poorly planned and ineffectively carried out. Gilbert stated in 1897:

During the period of my incumbency as superintendent, I have traveled to some extent and have made it my business to visit the penal institutions of seven other states, and I must say that I feel somewhat humiliated in being forced to the admission that Oregon has the poorest on the line of conveniences, sanitary conditions, furniture, appliances, buildings and everything.... ${ }^{28}$

Gilbert was correct in his analysis and assessment of prison conditions at the Oregon State Penitentiary. His analysis, however, was never translated into an effective plan of action. The problem identified was never tackled or resolved. In fact, Gilbert told a bold-faced lie when he claimed that "many of the evils I found existing have been corrected...."29

Gilbert, however, pointed to prison discipline as a "success" within his administration. During his four year tenure the superintendent saw only fourteen convicts scale the walls and escape into the woods of south Salem. After his first two years he reported that "not a single case of insubordination, or serious trouble of any kind, has occurred...." ${ }^{130}$ Gilbert was an adamant defender of corporal 
punishment for the persistent, incorrigible offender.

When Gilbert failed to use prison labor for the financial benefit of the prison, he seems to have employed it as an effective measure of discipline. The system of selecting certain prisoners for positions of trust was readily adopted by Gilbert upon his assumption to power. It "places the convict on his honor, it makes him feel that someone sees in him yet a spark of manhood, and that there still remains hope for good citizenship."31 During a twenty-two month span of Gilbert's rule, three hundred forty-eight trustees were selected and placed beyond the prison's walls. Of those trustees only nine escaped, two of whom were quickly captured.

The employment of trustees was not an innovation of the Gilbert administration. Gilbert justified its continuation, however. He stated "no law is found for any such proceeding, but having been done under all administrations, and no questions raised, it may be presumed to have become a law of itself."132 Gilbert not only perpetuated prison policy, but failed to implement penal innovations. It was Gilbert, a conservative Republican, who first gave support to the idea of prisoner classification in Oregon. This classification categorized prisoners into groups depending on their trustworthiness. Gilbert's plan, however, was never implemented. The lack of an adequate explanation for it not being implemented suggests that either Gilbert failed to garner sufficient support for his recommendation or that Gilbert himself lacked the initiative in pursuing this innovative policy. In any event, the policy was never adopted. 
Contrary to their initial intent, Governor Lord's and Superintendent Gilbert's keen vision and analysis crumbled under the weight of financial pressures and the principle of self-preservation. The gargantuan enterprise of the prison was beyond the control of the governor and the superintendent. The institution and the institution's administrators promoted internal preservation and perpetuation. One example of administrative stagnation is their failure to implement innovative plans like inmate classification. The deplorable conditions were identified, but not improved. The crisis was not rectified, but fortified. An entrenched stagnant bureaucracy gains strength from inaction as questionable policies become time-proven practice. The Oregon State Penitentiary stepped further into institutional stagnation. Reform never crystallized, but was illuminated to the prisoners. Stagnation was breeding crisis and chaos. The cycle of crisis and equilibrium still turned. It was stagnation and political shuffling that gave birth to the tragedy of the Tracy-Merrill affair.

The tragedy of the Tracy-Merrill affair, however, does not rest solely in the escape and bloody aftermath, but also in the prison's failure as a reformative and rehabilitative institution. It rests in the failure of the prison, before and after the crisis, to respond to a crisis. J.D. Lee claimed that "the outbreak was entirely unexpected, and, under the circumstances, could not be prevented. ${ }^{133}$ Nothing could be further from the truth, however. Lee's inability to see the trouble of pairing criminal partners in one cell is only one example of his naivete as a prison administrator. 
Detective Joseph Day of Portland, a former guard at the prison, stated that Tracy and Merrill "...should not have been allowed to be near each other to hatch touble." 34 Superintendent Lee responded by asserting that the incarceration of Tracy and Merrill together was not the "work of inexperienced men. ${ }^{135}$ Lee pointed to Warden Brophy and Warden James's long careers in prison work. Lee failed, however, to point to the chaos within those years and the stagnating policy since then. In his 1901 Biennial Report Lee gave the appearance of being a strict disciplinarian. He wrote, "Laxity in discipline is a mistaken kindness to prisoners. It invites insubordination and attempts to escape which usually result in a loss of life or of merit time. ${ }^{136}$ And, indeed, Lee was strict in many respects. It is highly probable that Tracy and Merrill wore the "Oregon Boot" more than they were free of the cruel device. But further preventive measures could have easily been taken. Detective Day referred to the use of Gatling guns at San Quentin and suggested their employment at Salem. A Gatling gun had been deployed at the prison as early as the Berry administration, but with political shuffling its use slipped into oblivion.

Lee did point to poor wall construction and insufficient night guards as plausible factors in the enticement of the escape. To stem the further tide of escapees, Lee had the big piles of moulding boxes around the stove foundry removed. It was here that Harry Wright had cached the Winchester rifles used in Tracy and Merrill's escape and subsequent flight. Electric lights were also provided at various points around the walls. ${ }^{37}$ 
The force of guards at the penitentiary, particularly at night, was simply not large enough to prevent outside interference. A single watchman patrolled the area of the rear yard where the foundry shops were located. After the escape, Superintendent Lee hired two extra guards for night service, and during the next legislative session, Governor Geer urged the assembly to make provision for the permanent maintenance of a proper guard.

Still, the institution was a warehouse of violence. The disciplinary ecords of the period lists dozens of vicious offenses, like fights and stabbings, that occurred weekly. Reformative and rehabilitative measures were not being employed. Lee responded to the reformer's pleas, "It has frequently been urged that the convict should be taught a trade during his incarceration in the state's prison. That is next to impossible in an institution like ours. ${ }^{138}$ It was impossible to teach a convict a trade when the institution was exploiting his labor for its own preservation. It should have been exploiting the convict's desire for freedom and his intellect in order to make the institution extinct. Reverend W.G. Eliot, Jr. of the Unitarian Church in Salem condemned the contemporary economic system for its impact on society and urged that it be held "...responsible in a measure for criminal classes." The jail and penitentiary, Eliot cried, should be a tool of social necessity, not of public vengeance. But Eliot saw the prison from a narrow perspective. "Education alone," he said "is not a solution. A rogue by nature, a man's roguery is multiplied by education. ${ }^{139}$ It was obvious that Oregon had a delicate and complex issue on its hands. One measure taken to stem the problem in prisons 
took effect exactly one year after the Tracy-Merrill affair. In June 1903, the state legislature adopted the death penalty.

The death penalty, however, was an ineffective tool for controlling the existent inmate population. The reforms of Superintendents Lee and James were temporary. Between 1902 and 1905 there were only six escapes, two of which were Tracy and Merrill. In 1905, however, the legislature passed penal legislation enacting Oregon's first indeterminate sentence law and widened parole authority for the governor. The inmates must have been exceedingly pleased with new laws for it meant the hope of release from the prison's deplorable conditions. Yet, very few realized these hopes as political maneuvering and bureaucratic channels blocked their release. A few did manage to receive parole, but the law generally benefitted only the newcomers, not those inmates already sentenced and incarcerated. Frustrated with the "dashing of hopes" inmates returned to escape as their only option for release. The escape records for this period show a dramatic increase. Beginning with three escapes in 1905 the numbers steadily rise to 1909 when thirty convicts crossed the prison's walls to the outside. Between 1909 and 1915 there were 165 escapes from the Oregon State Penitentiary. These numbers would not be matched until the 1940s and 1950s.(See Figure 3.)

The number of escapes during this period and the accompanying tension can again in part be attributed to the shuffling and turnover of superintendents at the prison. After Superintendent James's term of office the prison saw five superintendents over a three year period. With each new superintendent the 


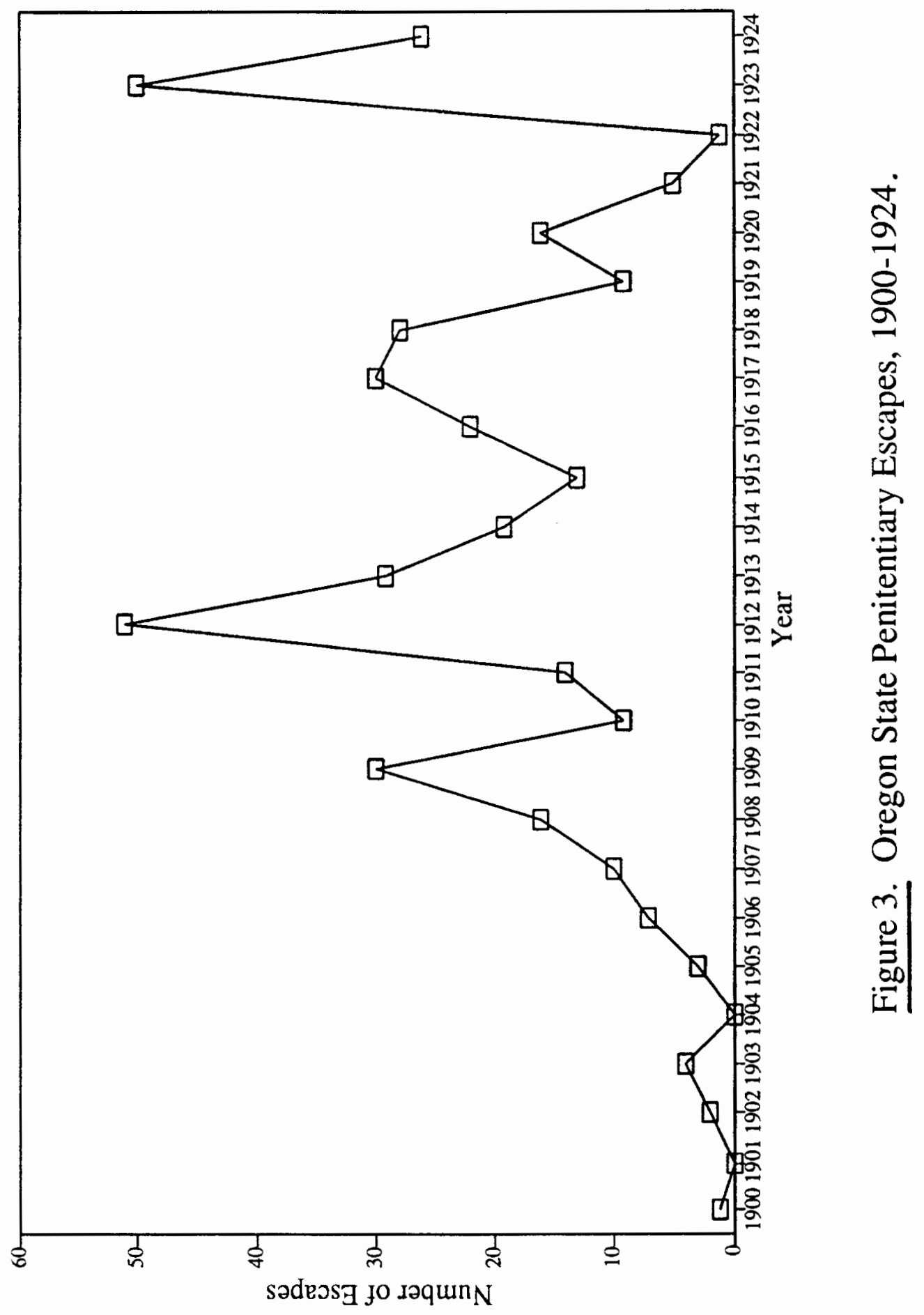


convicts gained hope of more lenient treatment and the possibility of their release. As an inmate in 1913 summarized, "Every change of governors was looked forward to with much speculation and hope." In each case, however, neither lenient treatment nor release was achieved. The turnover of these superintendents and the inconsistency in policy resulted in misbehavior.

Misbehavior, from smoking to attempted escape, was dealt with severely. The severity of the discipline, however, depended in part upon the inmate's chosen faith. Disciplinary records reveal that between 1909 and 1919 Catholics suffered disciplinary discrimination at the Oregon State Penitentiary.

The most frequent offenses during this period were smoking, drinking, and gambling. The most frequent disciplinary response involved cuffing the inmate to the cell door preventing him from sitting down or relaxing all day.

In examining discipline in relation to creed we find some startling results. In a sample of 265 disciplined inmates Catholics were significantly lower in their misbehavior than any other creed. Protestants and those inmates claiming "no creed" were slightly above average. Mormons, Jews, Free Thinkers, and Buddhists--a tiny number, in all less than ten--posed the most problematic to guards with incredibly high misbehavior. The ranking changes, however, when we examine the prison's disciplinary response. In this case the "no creed" inmates received the lowest punishment on average while the Catholics received the harshest. This is to say, Catholics committed the least severe offenses in the prison and yet received the harshest punishments.(See Figure 4.) These measures 


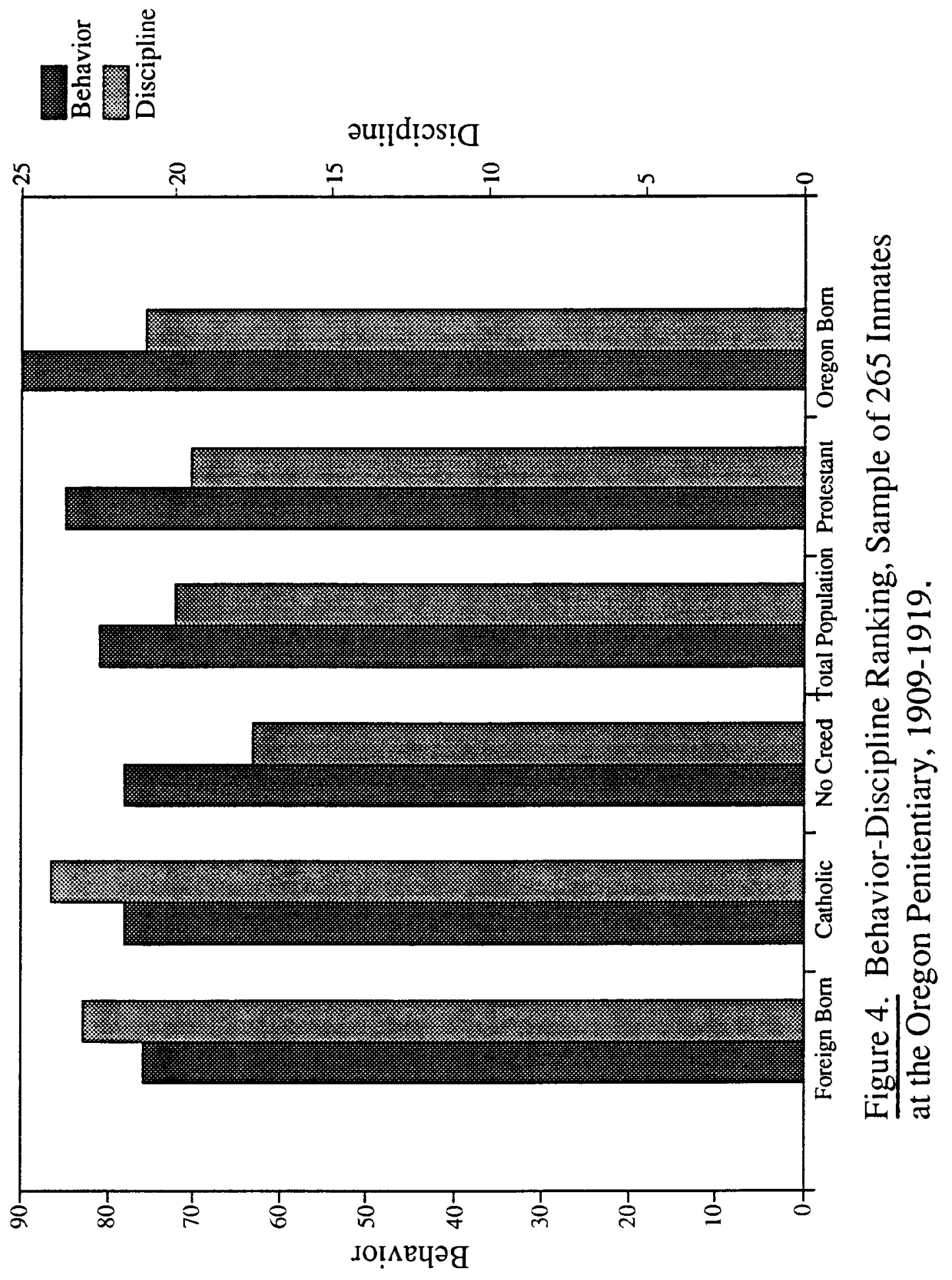


may also apply to nativity, county of criminal origin, occupation, and age.

Needless to say, disciplinary discrimination did exist behind the walls at the Oregon State Penitentiary. ${ }^{40}$

Coupled with administrative shuffling and poor internal conditions inmates naturally felt compelled to free themselves through escape. Plotting insurrection and escape during this period were inmates Carl Panzram (then known to officials as Jeff Baldwin) and his half-simple ally Otto Hooker. In 1915 tensions within the prison reached a boiling point and it was Hooker who fled from the prison and into the timbered outskirts of Salem. Another cycle was completed as Hooker launched the prison into another episode of crisis. 


\section{ENDNOTES}

${ }^{1}$ W.N. Carter, Harry Tracy: The Desperate Western Outlaw, (Chicago: Laird and Lee, 1902).

${ }^{2}$ Biennial Report of the Superintendent of the Penitentiary, 1 October 1902, (Salem: W.H. Leeds, State Printer, 1902), p. 16.

${ }^{3}$ Carter, Harry Tracy: The Desperate Western Outlaw, p. 15.

${ }^{4}$ Biennial Report, 1 October 1902, p. 16.

${ }^{5}$ Carter, Harry Tracy, pp. 13-14.

${ }^{6}$ Ibid, p. 14.

${ }^{7}$ Ibid., p. 19.

${ }^{8}$ Tbid., p. 34.

${ }^{9}$ Biennial Report, 1 October 1902.

${ }^{10}$ Carter, p. 64.

${ }^{11}$ Ibid.

${ }^{12}$ Oregonian, 10 June 1902, p. 5.

${ }^{13}$ Oregonian, 15 June 1902, p. 7.

${ }^{14}$ Oregonian, 13 June 1902, p. 6.

${ }^{15}$ Van Tiffin (inmate number 4382), Prison Tours and Poems: A Sketch of the Oregon State Penitentiary, (Salem: 1904), p. 64. Tiffin's name appears in several forms throughout prison records--Tiffin, Tiffan, Tifflin, and Tiffen. The spelling I have chosen (Tiffin) is the most frequent spelling and the one listed in the original register.

${ }^{16}$ Carter, p. 113.

${ }^{17}$ Biennial Report, 1 October 1902, p. 14. 
${ }^{18}$ Van Tiffin, Prison Tours and Poems, pp. 64-65.

${ }^{19}$ Biennial Report, 1 October 1902, p. 16.

${ }^{20}$ Lend A Hand, June 1916, p. 4.

${ }^{21}$ McAfee, p. 262.

${ }^{22}$ Joseph Kelley, Thirteen Years in the Oregon Penitentiary, (Portland: 1908), p. 128.

${ }^{23}$ Biennial Report of the Oregon State Penitentiary, 1897, (Salem: W.H. Leeds, State Printer, 1897), p. 4.

${ }^{24}$ Ibid., p. 7.

${ }^{25}$ Ibid., p. 14.

${ }^{26}$ Ibid., p. 58.

${ }^{27}$ Ibid., p. 16.

${ }^{28}$ Ibid.

${ }^{29}$ Ibid., p. 4.

${ }^{30}$ Ibid., p. 8. Gilbert's escape records are skewed by his refusal to include "trusty" escapes in the official escape count for the penitentiary. See McAfee, p. 264.

${ }^{31}$ Ibid., p. 9.

${ }^{32}$ Ibid.

${ }^{33}$ Oregonian, 10 June 1902, pp. 1, 5.

${ }^{34}$ Oregonian, 11 June 1902, p. 5.

${ }^{35}$ Oregonian, 13 June 1902, p. 12.

${ }^{36}$ Biennial Report of the Superintendent of the State Penitentiary, 1901, (Salem: W.H. Leeds, State Printer, 1901), p. 13.

${ }^{37}$ Tiffin, p. 65 .

${ }^{38}$ Biennial Report, 1 October 1902, p. 7. 
${ }^{39}$ Oregonian, 24 June 1902, p. 3.

${ }^{40}$ Disciplinary Records, 1909-1919, Oregon State Penitentiary; Oregon State Archives, Salem. Having ranked both misbehaviors and disciplinary responses by severity and intensity and assigning each disciplined inmate with a corresponding rank figure we can examine this disciplinary discrimination. The misbehaviors ranged from 1 to 9 with smoking the lowest infraction and escape as the highest offense. Likewise, disciplines were ranked from 1 to 8 with the wearing of stripes as the softest punishment and the "Oregon Boot" as the harshest punishment. Each disciplined inmate, therefore, received points for his various misbehaviors and a similar score tallying his discipline. It is therefore possible to measure and examine disciplinary tendencies. 


\section{CHAPTER V}

\section{"A CHANNEL FOR THEIR ANGER": 1915-1925}

The prison administration's inability to meet both the desires of the public and the governor, and still maintain a semblance of control at the prison, resulted in a high turnover rate of superintendents. On September 27, 1915, an enraged escaped convict further complicated the matter when he killed Warden Harry P. Minto. Harry Minto had previously served as City Marshal of Salem and Sheriff of Marion County. ${ }^{1}$ Minto took the top position at the prison on May 1, 1915, succeeding Colonel B.K. Lawson. When Minto was selected and appointed, Ben Olcott, Secretary of State and future governor, made the remark: "When Harry Minto starts after a man he usually gets him." ${ }^{2}$ But at $11: 30$ on that September night, Minto did not get his man, Otto Hooker.

Minto's stern and often brutal discipline helped rank the Oregon State Penitentiary as one of the worst in the North. "The bullpen--a prison within a prison--was to be remembered as a symbol of Minto's administration." Wandering from another form of discipline, the bullring, was viewed as escape and the guards on duty were authorized to shoot those inmates violating that rule. The guards Minto staffed at the prison were as rough and vicious, in many respects, as the incarcerated men. Minto rehired some old-line guards like Jim 
"Vinegar" Cooper, who was known throughout the prison as "Man of Flogs." He obtained his nickname as he was known to hoist inmates up on a column and whip them with cat o'nine tails. ${ }^{4}$ Cooper was joined by the Captain of the Guards, Jack "Jack of Clubs" Benson who employed equally brutal techniques. With harsh discipline the inmates were generally fearful and confused. "Confusion over conflicting orders from guards was generally looked upon as evidence of rebellion." ${ }^{15}$ Steel-tipped canes and bamboo prods kept the inmates at a distance, but also alienated them and stirred unrest. "Faced by eroding discipline, the big, bewildered warden accepted Vinegar Cooper's suggestion that troublesome prisoners be required to wear..." stripes. ${ }^{6}$ Contrary to the administration's expectations, however, the "hornet suits" as they were called, soon became a sign of respect and honor among the convicts.

Minto began to become paranoid about prison unrest. Both Minto and Cooper regarded the prison industries as a threat to internal discipline. As a result they consistently circulated and changed mill workers to prevent inmate stability and deter escape plots. Under Governor Withycombe's orders Warden Minto was forced to cut prison industry pay from one dollar to twenty-five cents a day. But the unrest the administration had attempted to stabilize was further enflamed. "Desperate men, suddenly finding a channel for their anger, risked anything to flee." ${ }^{17}$ And so on that September morning the lessons of the prison stirred Otto Hooker.

Early September 27, Hooker escaped from a work gang grubbing brush 
about one mile south of the penitentiary. Hooker was a twenty-one year old, convicted burglar from Umatilla County who had shown no disposition for trouble in the prison before the incident. But provoked by the bald and burly "ding" inmate, Carl Panzram, Hooker was agitated enough to escape and kill. ${ }^{8}$ Panzram later told officials, "I was always agitating and egging the other cons on to try to escape or raise hell in some way. I finally met a big, tough, half-simple Hoosier kid in there and I steamed him up to escape." Otto Hooker was Panzram's halfsimple Hoosier kid.

City Marshal J.J. Bergen initially pursued the escapee, but was wounded in an exchange of gunfire. It was from here that Minto picked up pursuit. Under the stars of that Monday night, Otto Hooker peered through the thick brush and spied Warden Minto and then fired. "The shot rang out loud and clear; the bullet entered the left side of the warden's nose, passed through his head and came out at the back of his neck just below the hairline on the right side."10 Flesh sprayed out of his head in a pink sweeping fan. His death was instantaneous. Minto's deputy, Walter Johnson, heard the gunshot and quickly ran to the side of his slain superior. He emptied a few futile shots into the brush where he believed Hooker had fled. The night prevented an immediate chase. The news travelled quickly and soon posses were organized in Salem, Albany, and Jefferson. Bloodhounds were again requested from Walla Walla to aid the two hundred armed men in hunting down the outlaw.

The next day a tip came in from a building contractor in Albany. J.R. 
Misner of east Albany reported to the police that he had heard a man's cough under his house. Officers were immediately called in and surrounded the structure. Hooker was ordered to come out. As he did so he made a sweeping action as if to grab a weapon. Anson Long, a Portland patrolman, drew his weapon and shot the surrendering convict. No weapon was found on Hooker. ${ }^{11}$

Salem and all of Oregon was shocked with the tragic news of Warden Minto's death. "The state has lost one of its very best citizens, and the prisoners of the penitentiary have lost their best friend," claimed Governor Withycombe. ${ }^{12}$ Stagnation at the prison had created an uncertainty in prison authority and forged a fearlessness among its inmates. The death of Harry P. Minto exemplifies the prison's inability to maintain control over its inmates in accordance with the public's demand for reform. A policy change was in dire need. But a policy change was not likely, as John W. Minto filled the vacancy created by the murder of his younger brother.

A change in policy had long been due. Ever since the tragic Tracy-Merrill affair the prison slowly slipped into a policy of persistent inaction. Like the old cliche, "The more things change, the more they are the same," the prison underwent much change in the first two decades of the twentieth century, but the change in policy only exacerbated the struggle betweenthe disciplinary and therapeutic penal philosophies. Any change from a previous policy created resentment among the inmates.

Responding, in part, to the Tracy-Merrill affair, the Oregon State 
Legislature in 1903 passed an act providing that all men convicted thereafter of murder and sentenced to hang should be executed at the state penitentiary. On the twenty-ninth of January, 1904, Harney County murderer Harry D. Egbert was the first criminal executed at the penitentiary in Salem. His experience with the legal authorities was not new. He had been imprisoned and released from the prison on previous charges. On warrant for a second minor charge, Egbert resisted arrest and killed two law officers. Egbert refused to live again behind the walls of the Oregon State Penitentiary. He made several attempts at escape and several futile efforts at suicide. Egbert's wish would be granted; he would not live behind the walls, but rather six feet under them. "His mood, defiant at first, changed toward the last, and as the days passed and death came gradually nearer, he became reconciled to his fate...."13 And so that Friday afternoon at the execution, the officers of the prison, a jury of twelve men, two physicians, and Egbert's relatives gave witness to the Oregon State Penitentiary's first execution. From that cold afternoon in January 1904, to November 3, 1964, when the death sentence was temporarily abolished, a total of ninety-two death sentences were issued in Oregon. ${ }^{14}$

Executions occurred often during the next half decade. While the death penalty became a disciplinary and legal tool of the penal era, reform swept through the remaining corners of the prison field. The Democratic gubernatorial administration of George Chamberlain (1903-1909) stopped the use of flogging and hosing within the prison's walls. Chamberlain's appointment to the position of 
superintendent was C.W. James. It was James's belief that corporal punishment ought to be discontinued, and he espoused the value of a less rigorous prison discipline. James, however, was not opposed to the use of the Gardner Shackle. The rehabilitative model was a facade for a still-lingering disciplinary philosophy. This is evident in the persistent use of harsh disciplinary measures like the "Oregon Boot." This "Oregon Boot" was one of the state's cruelest disciplinary techniques. The shackle, as mentioned earlier, was a medieval ball-like contraption made of "...separate pieces of heavy iron, curled in half circles, with small lips projecting out at right angles. These lips have holes punched in them in which rivets are placed to rivet them together."15 When riveted, the boot fit snugly around the ankle of the inmate. Its weight impeded walking or any rapid movement.

James's form of discipline existed purely in the control and structure of the inmate's daily life. If strictly regimented and channeled, he believed, the convict could learn the social channels beyond the gates of the penitentiary. Procedural control was the discipline under James's eight year administration. From the moment the inmate first stepped into the prison, his movements were regimented as his life became a line of procedures and policies. He was transported to the prison, his head shaved, and body bathed. After eliminating the inmate's presumed bodily filth, he was issued a cadet grey uniform. The legacy of Major M.P. Berry still lived. One convict commented that, "It is a memorable moment in a man's life when he dons a felon's garb, and that dressing into habiliments of 
shame is sometimes tearful."16 Striped uniforms, commonly associated with prisoners, were used only as means of punishment for those who broke the prison's internal regulations. After receiving their clothes, the inmates went to the records department where their vital statistics were taken. In the chapel, the prison chaplain read and explained the prison rules and regulations to the inmates. It was here that the chaplain first hoped to foster the trust of the inmate.

The daily life of the inmate was set to the tune of a chiming bell. Depending on the time of day, its ringing meant different things. At meals, when the bell chimed, "...those at each table, in prescribed order, arise, and with the signal to leave, file from the room."17 Those who failed to abide by the rules of the prison were subject to punishment. While now seen as cruel and unjust punishments, these methods were looked upon as the modern enlightened penal techniques of the day. The "Oregon Boot", the Bullring, and the Bullpen were all commonly used. The Bullpen was simply a dungeon-like cell used to isolate the offender. The Bullring was a similar cell, or often a courtyard where the offender, in this case, was forced to circle about the cell for a prescribed period, typically the eight hours he was supposed to be spending at work. Inmates caught smoking and urging insubordination were usually cuffed to their cell doors in an upright position preventing them from sitting or resting. The disciplinary records of this period show inmates were forced to stand anywhere from four to twenty-four hours. Isolation, however, was the most effective method of enforcing discipline. 
"...Unruly prisoners, after a short period of confinement here, soon see the folly of disobedience and promise conformance to prison rules."18 Rules, however, changed with each new administration. The struggle between the therapeutic and disciplinary philosophies still raged on.

Over the years the prison had been continually subject to progressive liberal forces. Society's understanding of crime expanded. Knowledge reformed the ranks of the prison. For example, acts which had been seen as crimes earlier were now seen as inevitable consequences of mental illness. Society did indeed shape the body of laws and therefore construct its own prison population. Society set the laws and determined which actions were criminal and which were punishable by incarceration. But with this expanding body of knowledge and understanding came a frustration toward those convicts who did not fit within that mold. Roy DeAutremont, as we will see in a later chapter, did not fit society's typical understanding of "criminal." A lack of understanding, or ignorance, bred an uncontrollable fear within the staff and administration at the Oregon State Penitentiary. This fear was only overcome, by these individuals, through physical force. Accustomed in their own lives to the employment of force and violence, the staff subjected brutal discipline upon the inmates in order to control them and assuage their own personal fears.

Conditions within the prison's walls were cold. The men inside passed their lives in crime and servitude. Inmate Van Tiffin testified that a significant portion of the inmate population suffered from an addiction to morphine or cocaine. 
Tiffin wrote in 1904, "I have observed that, though suffering painfully when first deprived of their drug, they soon improve and gain fresh rapidly. Although poor and pale, and with other conditions that always follow its use, their condition, mentally and physically, shows rapid improvement."19

When the bells chimed again, the inmates rose and returned to their cells. The furnishings of their $6 \times 7 \times 9$ cell depended solely on the behavior of that prisoner. "If he conforms to prison discipline he is allowed many privileges." ${ }^{120}$ The prison cells in 1904 were narrow places. A perforated disc on the ceiling served as a ventilator, though its effectiveness was questionable. In one corner was a sink and fastened to the wall was an iron table. Canvas bunks swung fom the gas pipes and a stool completed the provided furnishings. Cleanliness in the cells was especially promoted. Each inmate fashioned his cell into his own home. "Interior beauty may solace imprisonment," an inmate wrote, "but it does not make servitude less real. The padlocks clash as sternly as before, the prison bars echo just as harshly, the bells mean the same obedience, the same duties follow day by day; time still drags...."21

The prison administration did not provide the inmates with sufficient work responsibilities or with leisure activities that would restore good habits and selfworth. The new modern prison was still not a place of reform or rehabilitation, but a warehouse. Convicts lived there, existed there, while waiting for the passing of time. Time dragged on. While they waited, the prison administration exploited their physical labor. "Idleness," Superintendent James wrote, "...is a great breeder 
of mischief among free men, and is more to be feared in the case of convicts...."22 Prisoners during the previous ten years had been employed under the state contract with the Loewenberg-Going Company. Each inmate working for this contractor was paid three and one-half cents per hour. The contract, however, expired in July of 1905 . Over one hundred and seventy convicts were left unemployed. The idleness of the inmates became a great concern to Superintendent James. The financial success of the institution was also jeopardized. Loewenberg-Going could not be convinced to renew the contract. James offered a suggestion to the legislature; he claimed that "both ample land properly improved, a system of farming and rotation of crops could be inaugurated which would go far toward making this institution self-sustaining..."23 Before the expiration of the Loewenberg-Going contract the inmate's cells were "...cold, lonely and silent: the life that animates them is gone--the picture lacking. ${ }^{124}$ After the expiration, however, those cells were filled with pacing convicts, eager, trapped men, full of emotions. Those men who still had work in one of the various prison industries began avoiding duty by "...feigning sickness...."25 The institution was ripe for a riot or mass escape.

Superintendent James maintained control of his unruly prisoners, however, by slowly yielding to the pleas of outside reformers. Structurally, the prison underwent renovation and addition. A new dining hall was completed in February 1904. Two hundred and sixty-four prison cells in four wards comprised the living center of the prison. The prison's wings were large, "...wide and high heavily- 
barred arched windows" providing light and ventilation. ${ }^{26}$

James's laxity in policy enforcement encouraged greater freedom within the walls. Music, previously prohibited, was allowed under the James administration. Van Tiffin, inmate 4382, wrote an assessment and description in 1904. "As we ascend them we hear a banjo tumming, and down the tier a mandolin's sweet notes in 'Silver Bells'. You wonder, perhaps, at this, and ask if music is permitted. Yes. Prisoners who have a talent for music, those who are anxious to learn, or those who assist in chapel entertainments, are allowed to have musical instruments, and playing is confined to certain hours, and in the cells permitted under certain rules. ${ }^{27}$

Intellectually, the prisoner's world was opened. The prison library was enhanced and a wider variety of works allowed. The library contained about 2500 volumes embracing fiction, juvenile stories, history, biography, travelogues, and poetry. A nineteen page book of poems was published by inmate 4693, entitled Poems. $^{28}$ In the account, the poets detail the sorrow of prison life, religious awareness, and even current political events. "A Freedom's Cry" by inmate 3485 tells of the tragic Russo-Japanese War, news of which had only come through the grapevine of the prison.

Intellectually and artistically, the inmates were given a great opportunity when in June of 1903, the idea of the Oregon State Penitentiary publication, Lend A Hand, was inaugurated. ${ }^{29}$ Deputy Warden Johnson S. Smith was instrumental in its initiation. The Oregon Prisoners' Aid Society (OPAS) also helped establish 
this six-page $11 \times 15-1 / 2$ inch paper. At a subscription rate of fifty cents per year, inmates could be informed of prison activities as well as the staff's off-duty activities and vacations. Its two decades of success as a prison publication can be attributed to the cooperation between the inmates, penologists, community, administration, and staff. It is from these pages that the historian catches a glimpse of daily prison life.

The Oregon Prisoners' Aid Society was not only influential in creating the Lend A Hand publication, but other measures within the prison as well. It was to its criticisms that the James administration responded. The OPAS was founded in late April 1903, by E.W. St. Pierre, the acting chaplain of the prison. His organization, OPAS, promoted prisoner classification and separation, parole laws, and an improved prison library. The 1905 legislature set up Oregon's first indeterminate sentence law with widened parole authority for the governor. Prompted by OPAS, this was an advanced step in penal legislation. It sought to treat inmates along individual lines rather than in a collective fashion. Through this individualized treatment the problems of criminal association were resolved by isolating inmates and providing sentences and programs tailored to their specific offense. But again, the reforms were addressed through an application of penal theory and as long as the prison is offered as its own remedy, the crises and pathology of power will continue.

The OPAS and other outside interest groups made demands and held the James administration accountable for the entire prison "community". This outside 
interference weakened, if not destroyed, the administration's authority. Nationally, according to James Jacobs, an "...'old order' of authoritarian control was followed by a period of mild reform, and mild reform only produced increased tension and hostility between prisoners and administration. ${ }^{130}$ This may also be the case in Oregon. Inmates began looking anxiously to the newest governor, hoping for parole or pardon. Prison reform had bred hope among the inmates and yet most of their dreams were simply illusions. A modern prison scholar wrote that "Privation is far less cruel and less likely to cause violence than is the dashing of hopes." ${ }^{131}$ Chaos in the penitentiary had seemed imminent, but reform had stemmed the tide. Now that same reform shifted and electrified discontent. At the end of the first decade of the twentieth century, Oregon's political power structure was transformed. Governor George E. Chamberlain resigned on February 28, 1909, to assume a position in the United States Senate. His vacant post was filled by Republican Secretary of State, Frank W. Benson. Benson's mental failure led to his inability to act and consequently power was transferred to his colleague, Jay Bowerman, who served as acting governor until January 1911. Both Benson and Bowerman, as Republicans, saw Oregon's political and institutional future in ways far different from their Democratic predecessor, George Chamberlain. One example is Bowerman's open opposition to convict labor as a means of reform. Reform-minded policies, however, returned to the Capitol on January 11, 1911, upon the election of Governor Oswald West. Despite his election, it was obvious that conservative forces were powers to reckon 
with in the State of Oregon.

The problems associated with political shuffling were coupled with sharp criticism from the OPAS, which exerted a great influence over the West administration and appointees at the prison. During West's governorship the prison saw three superintendents: the outgoing C.W. James, Frank H. Curtis, and J.J. Bergen. In the two years after West's administration, three more superintendents would be added to that list: B.K. Lawson, Harry P. Minto, and John W. Minto. Political unrest, administrative uncertainty, and public criticism set the stage for prison uncertainty and, therefore, crisis.

The administrators at the Oregon State Penitentiary felt that the death penalty would solve all their problems. They saw it as a deterrent to crime and as a deterrent to internal prison unrest. The first decade of its existence showed a marked increase in the imposition and disposition of the sentence.

The prison's administrators looked to the death penalty for control, but Governor West consistently overrode the legal decisions placed by the courts. West was personally opposed to the death penalty under any circumstance and in a three and a half year period he commuted nine sentences. ${ }^{32}$ Two failures of West's lenient policy are Paul Pender and Lem Woon. Pender was sentenced to die in early 1914 , but his sentence was commuted by West just in time for Thanksgiving of that same year. A few years later he was pardoned and released under the parole law that Governor West had so adamantly defended. In 1927, Pender assaulted and attempted to rape a young woman. He was given a life 
sentence and died behind the prison's walls in $1950 .^{33}$ Lem Woon, a native Chinese, was given a death sentence and entered the prison in July 1908 . In November 1913, West commuted his sentence and later issued a conditional pardon. Woon, like Pender, would return to the prison despite his new lease on life. $^{34}$ West's failures, however, did not impair his eventual goal. From 1915 to 1919, Oregon abolished the death penalty. Governor West's humanitarian policy was slowly binding the hands of the prison administration. Unable to effectively employ their "sole" control measure, the death penalty, the authorities at the prison slowly lost control. Escapes during this period made dramatic increases, consistently reaching above thirty escapes each year. Not until the 1950 s would these rates be duplicated. The prisoners loved the laxity in discipline. "No more lash; no more bullring; no more favoritism; prison contract labor gone forever," cried the inmates "and now we are at least going to be treated as human beings...." ${ }^{135}$

West's penal policy was not without control, however. Both he and his successor, James Withycombe, advocated sterilization as a means of curbing social deviancy. West widely supported Dr. Bethenia Owens-Adair's eugenic legislation. Eugenics is the improvement of mankind's innate capacities. It was a concerted effort to breed better people by encouraging people of desirable traits and discouraging the breeding of people with undesirable traits. Therefore, criminals, they argued who "innately" possessed undesirable traits, would be discouraged from breeding. They would be discouraged by simply sterilizing them 
involuntarily. ${ }^{36}$ The first sterilization statute was passed by the legislature in 1913, but repealed by the public through the initiative and referendum. OwensAdair's persistency eventually prevailed and the Oregon Board of Eugenics was established in 1917. Governor Withycombe was a critical factor in its passage into law. Overall, Governor West's inconsistent humanitarian penal policy "...proved a flat failure...." ${ }^{137}$ Withycombe and his political allies enforced a more rigorous discipline policy.

Harry Minto too had initiated a rigorous discipline policy, but it also fell victim to the prison crisis. John Minto took the position three days after his brother's murder and immediately announced that he would cooperate with the Board of Control and execute his brother's programs. Both Harry and John had applied for the warden position in 1915, but when the field was narrowed down to just Harry and himself, John withdrew in favor of his brother.

Minto had served as Portland's Chief of Police, U.S. Marshal, and as Postmaster of Portland. ${ }^{38}$ He was not an experienced man in the corrections field. In September 1915, he assumed the duties of warden of the Oregon State Penitentiary and with it a heavy burden. John W. Minto had inherited a confusing penal mire.

The major agitator within this mire was inmate Carl Panzram, alias Jeff Davis or Jefferson Baldwin. Panzram had previously served time in the Montana State Reform School in Miles City and later in the Montana State Penitentiary at Deer Lodge. He was most obviously, in John Irwin's term, a "state-raised youth" 
and doomed to a career of crime. He was arrested in 1915 in Astoria, Oregon, and sent to the Oregon State Penitentiary under the name of Jeff Baldwin. Throughout his criminal career he murdered over 21 people, committed thousands of robberies, and indulged in countless acts of sodomy. ${ }^{39}$ "For all these things," Panzram writes, "I am not the least bit sorry. I have no conscience so that does not worry me. I don't believe in man, God nor Devil. I hate the whole damned human race including myself."40 Karl Menninger,M.D., would later refer to Panzram as the "...logical product of our prison system." ${ }^{141}$ He was a brutal, barbaric murderer. In May 1916, under the administration of Harry Minto, Panzram set fire to a storehouse of flax damaging $\$ 20,000$ worth of prison property. ${ }^{42}$ The new warden, John Minto, had his hands full. Like his brother, Minto attempted to enforce strict discipline and frequently employed flogging and hosing as a form of punishment. Governor Withycombe, however, caught word of the prison brutality and sent a three-man reform commission to investigate the allegations. The investigative commission confirmed the reports and denounced the brutal practices. "When Panzram sensed the letup, he banged his bucket all night long on his cell door and shouted curses at the guards. When the other inmates realized that retaliation was not forthcoming, they joined him." ${ }^{143}$ Shortly thereafter, John Minto resigned.

Panzram's behavior points to internal tensions involved in prison reform. Tensions were heightened by conflicting intent. There were internal and external intentions involved in prison reform. The external reform of the institution 
involved freeing the prison from financial and political entanglements. It was meant to eradicate the abuse of the prison as a tool of power and make it a safe and self-sufficient institution. Internal reform involved a more delicate challenge in practice and principle. The institution's reformatory and rehabilitative principles were reexamined and reapplied. Unfortunately, reform (in both cases) was slow to arrive at the Oregon State Penitentiary. In fact, reform during this era had two fatal consequences. Reform at the penitentiary heightened the hopes of inmates who, upon disillusionment, became highly vocal and militant convicts. Violence was a natural outcome of such frustration. Furthermore, as seen in Carl Panzram's case, public pleas for reform seemed to validate unjust and inhumane treatment and therefore gave permission for violence, unrest, and upheaval. In both cases, unwanted reform resulted in the abrupt end of the "reforming" superintendent's tenure. And in almost every instance the heir to the vacant superintendency adopted a platform of force and vigilance to discipline his unruly inmates. Naturally, this force and legal violence received sharp barbs from the Oregon public. And so the paradox of prison reform viciously runs on.

And, indeed, reform was needed at the Oregon State Penitentiary. The cell sink and soil pot system were not in accordance with modern sanitary standards. ${ }^{44}$ The inmate's meals were usually composed of mush, brown beans, bread, and water. "Congenital homosexuality", as defined by the prison administration, was rampant throughout the institution. The number of escapes continued to rise. The prison was still plagued by administrative inconsistency. 
Between 1917 and 1923 the prison had six superintendents and only under one (L.H. Compton) did prison escapes subside. Again, the prison was heading toward another critical point in its development. In 1925 the prison completed another cycle when inmate Tom Murray led a series of escapes and disturbances that would force the prison to reexamine its policies and procedures. 


\section{ENDNOTES}

${ }^{1}$ Beverly Elizabeth Lowe, John Minto: Man of Courage, 1822-1915, (Salem: Kingston Price and Company, 1980), p. 97.

${ }^{2}$ Oregonian, 28 September 1915, p. 14.

${ }^{3}$ Thomas E. Gaddis and James O. Long, Killer: A Journal of Murder, (New York: The MacMillan Company, 1970), p. 84.

${ }^{4}$ Ibid., p. 72.

${ }^{5}$ Ibid., p. 85.

${ }^{6}$ Ibid., p. 80.

${ }^{7}$ Ibid., p. 88.

"Ding" is a prison subculture term referring to "crazy" or mentally unbalanced inmates.

${ }^{9}$ Gaddis and Long, Killer: A Journal of Murder, p. 81.

${ }^{10}$ Lowe, John Minto: Man of Courage, 1822-1915, p. 96.

${ }^{11}$ Oregonian, 29 September 1915, p. 2.

${ }^{12}$ Lowe, p. 97.

${ }^{13}$ Tiffin, Prison Tours and Poems, p. 55.

${ }^{14}$ Hugo A. Bedau, "Capital Punishment in Oregon, 1903-1964," Oregon Law Review, vol.45, December 1965, p. 5.

${ }^{15}$ Tiffin, p. 41.

${ }^{16}$ Ibid., p. 4.

${ }^{17}$ Ibid, p. 33.

${ }^{18}$ Ibid., p. 21.

${ }^{19}$ Ibid., p. 14. 
${ }^{20}$ Ibid., p. 19.

${ }^{21}$ Ibid.

${ }^{22}$ Biennial Report of the State Penitentiary, 1905, (Salem: J.R. Whitney, State Printer, 1904), p. 8.

${ }^{23}$ Ibid., p. 5.

${ }^{24}$ Tiffin, p. 18.

${ }^{25}$ Ibid., p. 35.

${ }^{26}$ Ibid., pp. 8-9.

${ }^{27}$ Ibid., p. 18.

${ }^{28}$ Poems is an articulate account of prisoners' passions inside and outside the prison's walls.

${ }^{29}$ Lend A Hand was an Oregon State Penitentiary newspaper written, edited, and published by the prison's inmates. The magazine covered all aspects of life within the institution and included articles by noted penologists of the time as well as local penal experts.

${ }^{30}$ James B. Jacobs, Stateville: The Penitentiary in Mass Society, (Chicago: The University of Chicago Press, 1977), p. x.

${ }^{31}$ Lester Douglas Johnson, The Devil's Font Porch, (Lawrence, KS: The University Press of Kansas, 1970), p. xi.

${ }^{32}$ Bedau, p. 28.

${ }^{33}$ Ibid., p. 33.

${ }^{34}$ Ibid.

${ }^{35}$ Lend A Hand, March 1913, p. 13.

${ }^{36}$ Bethenia Owens-Adair, Human Sterilization: Its Social and Legislative Aspects, (Portland: Owens-Adair, 1922).

${ }^{37}$ Oregonian, 28 July 1923, p. 5.

${ }^{38}$ Ibid.

${ }^{39}$ Gaddis and Long, Killer: A Journal of Murder, pp. 12-69. 
${ }^{40}$ Ibid., p. 12.

${ }^{41}$ Ibid., p. 14.

${ }^{42}$ Ibid., p. 86.

${ }^{43}$ Ibid., p. 87.

${ }^{44}$ Report of the Commission to Investigate the Oregon State Penitentiary, (Portland, 1917). 


\section{CHAPTER VI}

\section{"HAVEN FOR BEAST": 1926-1938}

At 9 a.m. on March 28, 1924, six convicts escaped from the prison. They had battered a lock from a heavy iron door, pried the bars of the window, and crawled to the outer yard. Once outside, it was only a few moments before they had scaled the wall near the warden's office and dashed eastward to the timbered country. Penitentiary officials earlier had received a tip that a break was planned for that afternoon, but the information was not acted upon and the escape was to go on as planned. The escaping inmates, however, heard about the leak of information and so took immediate action. They escaped that morning rather than await potential suppression of their plans. William Johnson, one of the escapees, surrendered to guard Lute Savage shortly after scaling the wall. ${ }^{1}$ Johnson had just previously returned to the prison after a six and one half month escape. Chip Weekley was captured two days later roaming through the thick underbrush outside of Salem. Tom Murray, the recognized leader of the group, then split from the rest of the group, leaving Joe George Jackson, Ellsworth Kelley, and "Oregon" Bert Jones travelling together. On the second of April, Kelley and Jackson were captured; exhausted and hungry they surrendered themselves to their pursuers. Murray was captured the following day, but Bert 
Jones still eluded the posse. He was captured shortly thereafter.

Governor Walter Pierce proclaimed to the public, "I have not forgotten that the penitentiary was built to keep criminals away from society. ${ }^{\prime 2}$ On August 12,1925 , however, the criminals moved into the outside society. Inmates Tom Murray, Ellsworth Kelley, "Oregon" Bert Jones and James Willes escaped from the penitentiary. Again, Murray was their leader. Despite their harsh reputation and past escape attempts, Murray, Kelley and Jones had cells within a short distance of one another. Using an auger, the four convicts drilled a hole in the roof of the prison, through which they climbed out of their cell block. They then dropped to the ground on a makeshift rope. The group then split and ran in two directions, both circling back toward the arsenal where they charged the turnkey and armed themselves with pistols and rifles. From the arsenal window they shot guards John L. Sweeney and James Milton Holman and fled over the bodies of the slain officers. Guard Lute Savage was on the adjacent wall and fired on the convicts; he too was shot, but not killed. The convicts began to flee toward the state hospital. A shot rang out and "Oregon" Bert Jones fell to the ground. His companions looked back, but Jones waved them on. He was injured and capture was certain, but he was not dead. At the hospital the remaining three convicts grabbed a nurse, who escorted them to the street, where they commandeered a taxi. Taxi driver Zina J. Zinn was surprised by the sudden arrival of passengers. He later reported that Murray was seriously wounded in the abdomen and another was injured with a shattered arm. They later abandoned the taxi and fled 
on foot. ${ }^{3}$

The Oregonian reported that "As prison officials carried the body of Mr.

Sweeney from the post where he fell, a victim of a felon's bullet, convicts within the walls started a near riot. The men cheered, rattled the doors of their cells and chorused in catcalls." ${ }^{4}$ Their leader, Tom Murray, was free. Murray was a "genuine bad man" and a former San Quentin inmate. 5 He was serving a twenty year sentence for a bank robbery in Florence. Ellsworth Kelley was serving a twenty year sentence for aiding in a prison escape. Sentenced at the same time was Josephine County's most well-known criminal, "Oregon" Bert Jones. Jones was serving a twenty year sentence for assault and robbery. Now, with the exception of Jones, they were no longer captives of the prison.

But they were captives of another sort. Their every activity was regulated by the possibility of capture. Their pursuers's skills would have to be finely tuned before they would catch Murray, Kelley, and Willes. Oregonian correspondent Daniel Markel described the criminals's route:

Deep ravines, thickly studded with tall green spires; silent, mysterious ravines, hiding in their shadowed depths three escaped convict murderers; dark ravines with wild tangles of verdure as if by a devil conceived as secret passage ways for hunted man-animals, and about them fields of golden stubble, orderly farm yards, smooth roads and zig-zag fences...Beaver Creek and Drift Creek are primeval ribbons winding torturously through valleys of civilization...ever the haven for beast. ${ }^{6}$

Across the open plain and through the deep ravines the posse pursued the three convicts. Governor Pierce authorized the calling out of twenty national guardsmen to aid in the chase. Wilford Stilwell, the guard responsible for the 
prevention of a mass escape in 1883 , at age seventy-four, offered his services to the prison authorities.

Tom Murray was the obvious leader of the escapees. He was the brains, the nerve, and the energy of the outlaw trio. Murray led Willes and Kelley to a farm just outside of New Era, Oregon. There they befriended the farm owner and his family. C.L. Newman and his two boys, Leslie and Lyle, were shocked by the visit of the three men. The escapees were approaching their sixth day away from the prison. They ate heartily at the Newman farm. On the Monday following their mid-week escape, Tom Murray spent the afternoon teaching the youths poker and card tricks. C.L. Newman would later claim that he did not hate the bandits, but rather pitied them. ${ }^{7}$ He could see the pain and fear in their eyes even as they rested comfortably at the farmhouse. The three men read in the newspapers of their escape and subsequent activities. In a letter to the authorities, Tom Murray penned his own version of the situation.

"I knocked Slaughterhouse (Davidson) down with my fist and left him lying on the floor, begging for mercy," he wrote, "He was squeeling like a pig...." In an attached note to the letter the three convicts expressed their shock in hearing of Jones's death. "The last we saw of Jones he was sitting on the ground fully conscious but unable to walk, and if Slaughterhouse Davis shot him he must have walked up on him and shot him like a dog, giving him no chance." ${ }^{\prime 9}$ They further reported to the Newman's that they would not harm any man unless that man stood between them and their freedom. They also admitted their guilt, but 
"...branded the guards of the prison as cowards." ${ }^{" 10}$ The authorities would later criticize C.L. Newman for not reporting the inmates's presence to them earlier, but Newman defended his actions by pointing out that he was not willing to risk the safety of his own family for the capture of a criminal.

On August 22, Tom Murray was captured in Centralia, Washington. Kelley and Willes were later caught fleeing toward White Salmon, Washington. As he was transported back to Salem, Murray told reporters, "Tell the world for me that I am through doing time. If they swing me, all right; if they don't, I'm not going to do time."11 Murray lightened the subject, however, when questioned as to his destination during the escape he answered, "Hong Kong to buy some chop suey." 12

Indeed, crisis again had erupted within the Oregon State Penitentiary. The crisis in Salem had been brought on by politics and deplorable prison conditions. Internal and external spoils had eroded prison authority. The penal mire John Minto had inherited remained. Like his predecessors, Minto could find no solution to the crisis in the prison. And so the crisis brewed for ten years finally exploding with Tom Murray's escape.

In 1916 Minto was replaced by Charles A. Murphy. Before Murphy's arrival, the prison was riddled with distrust, jealousy, suspicion and vindictiveness. Changes, under Murphy, were rapid. He "...broke through the hard crust of 'system'," and "cleared the atmosphere of the 'prison' poison...."13 In the 1917 Report of the Commission to Investigate the Oregon State Penitentiary, board 
members L.J. Wentworth, E.E. Brodie, and F.W. Mulkey analyzed the prison conditions before the transition from the Minto administration to Warden Murphy was completed. They found conditions behind the prison's walls deplorable. "The cell sink and soil pot system is a disgrace to the state...." ${ }^{14}$ They recommended that new showers and bathrooms be installed. Prisoners were discovered kindling wood fires in their cells and using their night soil pots for stoves. During the frequent rain showers, inmates congregated in the unused industrial buildings and played Keno, dominoes, and other games. "Congenital homosexuality" was rampant throughout the prison. ${ }^{15}$ Conditions within the prison had slipped again into utter deterioration.

The summer of 1917 , however, will be "long remembered by the inmates for the privileges enjoyed and the general all-around prosperity for this institution."16 The Bullring had been maintained as a means of punishment for infractions of discipline. The men placed on the Bullring were forced to constantly circle the ring until their prescribed disciplinary sentence was completed or he dropped from exhaustion.

There was testimony before the Investigating Commission of 1917 to the effect that some prisoners were forced to walk the Bullring for months at a time. Both Mintos before the Murphy administration were opposed to the use of the dungeon. Those who were forced into isolation "...found no difficulty in cutting the bolts with a hacksaw."17 The Murphy administration quickly resolved the problem: the Bullring was abolished entirely and a new policy of discipline 
introduced.

Murphy's new discipline policy was a radical change from the past. The public, staff, and prisoners were shocked. At first, inmate Carl Panzram thought the new warden was crazy, maybe a fool, or possibly even "queer sexually."18 But Panzram was wrong. Murphy had seen that the traditional methods of achieving prison stability had not been effective. He abolished virtually every harsh punishment and established "KP--potato peeling in the kitchen--as the worst punishment a rulebreaker could receive. ${ }^{19}$ His soft approach to disciplinary policy was followed by a corresponding decline in disciplinary offenses. He hoped that leniency would have a positive effect on the inmates. Risking his own position he opened the prison's gates to the institution's most hardened criminals, including Carl Panzram. Panzram promised he would return each evening after work and, surprisingly, he did. In 1918, however, Panzram did escape. "I made a clean break. I have never been back since. I still owe 14 years there."20 Panzram never did make it back. In September of 1930 Carl Panzram was executed at the federal penitentiary at Leavenworth, Kansas.

The Murphy administration, in coordination with the Commission to Investigate the Oregon State Penitentiary, laid the foundation for Oregon's progressive penal policy. The intent of the commission was to "...outline an administrative system in reference to penitentiary treatment that shall be in accord with modern thought on the subject of penology."21 The commission possessed enough wisdom to know that the criminal problem could not be resolved through 
the penitentiary and discipline, but that these were only two steps in a larger social process. Earlier penitentiary policy had been based on the classic theory that punishment be based on uniform sentences for like crimes. This form of punishment, the commission argued, "...ran the risk of introducing a cruel and intolerable injustice, in that it brought together in perilous promiscous association those guilty of the same crime...."22 The board, therefore, suggested the prison adopt the Italian school in penal policy where the punishment was individualized.

In order to apply this penal theory, the board suggested the prison establish psychological and sociological departments as parts of the prison's medical program. It also fortified the indeterminate sentence and recommended a geographical ledger of inmate daily life be kept in order to give the Parole Board a better perspective of prison life. The geographical ledger was a daily account of each prisoner's whereabouts and a map of inmate and staff routes. They also recommended adopting the principles of Thomas Mott Osborne's Mutual Welfare League. Osborne, superintendent at the New York State Penitentiary at Ossining (Sing Sing), New York, and the leading penal expert in the nation, attempted a form of control in his New York prison whereby the inmates were given a degree of autonomy and self-government. Brodie, a member of the investigating committee, had visited the Connecticut State Prison, Michigan State Prison, Minnesota State Prison, and Sing Sing. Brodie was deeply impressed with the programs at all of the institutions where discipline was based on granting or withholding privileges. Sing Sing's self-governing body, the Mutual Welfare 
League, was successful, but was simply not old enough to warrant Brodie's complete approval. Despite Brodie's uneasiness, the Sing Sing program was suggested as an option for the prison to follow. ${ }^{23}$ The commission also suggested vocational training, compulsory military training and calisthenics. Learning from the Tracy-Merrill affair fifteen years earlier, the investigating committee prompted the prison to adopt a policy of one man per cell. Naturally, cell space and funding were influential factors in achieving this goal.

Warden Murphy's reform policies, however, were short-lived. Fifty-eight escapes during the span of 1917 and 1918 crippled his administration. His four successors over the next four years--Robert L. Stevens, Dr. Lee Steiner, H. Louis Compton, and J.W. Lewis--saw slightly over the same number of escapes in twice the period. ${ }^{24}$ Governor Walter Pierce's 1923 election was supposed to be the beginning of a resolution of Oregon's prison problems. The problems, however, had only just begun. Over the next four years the prison crisis was entangled in politics.

Pierce began his four year gubernatorial term with the controversial appointment of Johnson S. Smith. Smith openly acknowledged the difficulty of his task when he pointed to inherent administrative incompetence. "No one," Smith said, "knows anything about prisoners but prisoners."25 Smith was a humanitarian who espoused a "soft glove" approach in the handling of inmates. ${ }^{26}$ He believed in the inherent good in all men and that if given the opportunity for these characteristics to grow that the good in all men would flourish. Society had 
stifled the growth through economic, political, and racial oppression. Smith and others believed that through a "corrective" plan of reform the inmates could be rehabilitated and reinstated into the general community. His tolerant policy, however, resulted in thirty-seven escapes in his first six months as warden. Three inmates during Smith's administration had multiple escapes: George Jackson, George Holtzclaw, and Hubert Berry. The newspapers's coverage of Hubert "The Beer Bottle Bandit" Berry only magnified the prison crisis. Berry's escape brought the prison's problems to the forefront of public attention. Criticism from the press eventually led to Smith's removal. Smith struggled to preserve his power. He urged the public and politicians to have trust in the convicts despite the ongoing escapes. With rumors of his removal circulating about the corrections community, Smith attempted to alleviate the pressure by discharging several subordinate officers. Then in August 1923, a convicted forger, J.C. Connors, wrote a letter to Governor Pierce complaining of inconsistent parole laws. In his letter, Connors wrote, "On June 5, 1920, I was placed in the Bullpen for no apparent reason and without explanation. Existence in that place was a continued nightmare."27 Connors's nightmare was broken on August 11, 1923, when Governor Pierce paroled him. Connors's vivid description of the conditions within the prison shocked the Oregon public. Pierce's only choice was to remove Warden Johnson S. Smith and, in doing so, Pierce also appeared to be reforming the state's primitive parole laws. His removal of Smith was a well-planned political ploy. 
Taking over Smith's position at the penitentiary was fifty-six year old A.M. Dalrymple. Dalrymple was born in Delevan, Wisconsin in 1867 , and came to Oregon in $1892 .^{28}$ His experience in the corrections field was limited. He had been formerly employed at the prison in a subordinate position, but was fired by the warden for undisclosed reasons. His dismissal was approved by Governor Oswald West. Governor Pierce revived Dalrymple's reputation and career a decade later. Dalrymple had virtually no prison administration experience, but as a Democrat who had campaigned for Pierce, he was owed a reputable position within the state's inner workings. Apparently, in Pierce's mind, Dalrymple's brief stint at the prison was enough qualification to warrant his appointment. Dalrymple was also the type of character that he could easily manipulate without a serious uproar from Dalrymple himself. The governor was slowly fashioning the prison to his own design. Pierce claimed himself "instrumental" in the passage of a bill giving the governor control of the penitentiary without the interference of the Board of Control. Pierce stated, "The theory that I advanced was that the governor was virtually held responsible by the people for everything that happened at the penitentiary, which was true. The governor had the right to parole and pardon. It was believed by myself and others that it was best that he control the policies of penal institutions. My service as governor...convinced me of the justice of the law. ${ }^{129}$ Counter movements were made to wrest control from Pierce's hands and return it to the "general public." But Pierce was not resting on his laurels. To an Oregonian reporter he stated, "I'll fight to prevent prerogatives 
of the executive being given over to the Board of Control." ${ }^{130}$ Compromise was not in his nature. Disharmony was already being stirred up in Salem. Pierce's appointment of J.V. Starrett as the state parole officer was "purely political" and further exacerbated the tension. Starrett, a resident of Roseburg, was an active worker in the Pierce election campaign. He was also a paid organizer for the $\mathrm{Ku}$ Klux Klan and therefore "...wielded considerable influence favorable to the governor's candidacy."131

Criticism of Pierce's Klan affiliations began with evidence of the racist organization's penetration of state positions. Starrett, himself, immediately magnified the crisis when he began stepping beyond his own duties and powers and into those of Warden Dalrymple's. Starrett was intimate with the prisoners, heightening their hopes of pardon and parole, and thereby undermining the warden's authority. Pierce's two political appointments, Dalrymple and Starrett, were battling it out over control of the penitentiary.

Pierce eliminated much of the criticism with his program of reform. The prison when Pierce became governor was "...old, infirm, unfit, and...harbors many desperate men."132 An Oregonian editorialist placed the structure in the "horsecar period."33 Pierce's plan for modernization was supposed to solve these problems. A hydroelectric plant was built on Mill Creek and furnished power to the prison at a savings of $\$ 10,000$ a year. Every inmate capable of hard labor was employed in the plant's construction. A flax plant, a lime plant, and two linen mills were also built during this modernization period. During Pierce's prison 
labor program over $\$ 34,000$ was earned by the inmates in tailoring, shoe shops, and mills. The prison industries turned out over one thousand dollars worth of products a day. Pierce eased the sharp barbs of his critics. "It is a crime on the part of the state," he said, "to allow prisoners to spend their time in idleness while the taxpayers are compelled to contribute to their support."134

Pierce had found an idle group of men and had put them to work at a profitable industry. He had further stated that his industry program, coupled with the same amount of legislative funding appropriated during the last session $(\$ 420,000)$, would allow him to make the institution self-supporting. Despite its initial success, however, the prison industries soon disappointed Pierce. Opposition from labor unions and flax growers eliminated this new competitor. Pierce's financial reform survived the lost expectations of the prison industries, however. With a fifty percent increase in the inmate population one would expect a comparable rise in the cost of maintaining those inmates. The statistics show otherwise. During the $1925-26$ biennial period in which this fifty percent increase occurred, the operating costs dropped over $\$ 70,000$. Pierce's former critics praised him for his handling of the situation and claimed that the penitentiary was the "best managed" institution in Oregon. ${ }^{35}$

But the penitentiary was managed by two forces, an external force and an internal force. The external force was Governor Pierce and the Oregon State Legislature. The Starrett-Dalrymple dispute had undermined one another's authority. The power vacuum was filled by internal forces. It was essentially the 
convicts who ran the prison. Leland T. Murphy, a guard under investigation by the prison administration, later testified, "that practically all of the demands and whims of the prisoners had been gratified by convict-loving officials. ${ }^{1136}$

Gambling, desecration of the Sabbath, access to "merawanna", conflict of authority among the officials and employees, and a marked lack of discipline, combined to destroy the limited purpose and vision of the Oregon State Penitentiary. ${ }^{37}$ L. Rayburn, a former guard under the leadership of Warden Dalrymple, reported to the Oregonian that "...Dalrymple did not like the idea of guards shooting escaping prisoners, and I have heard him say if a guard killed a convict he thought the guard should himself be lined up against a wall and shot."138

This valuable news quickly traveled throughout the prison grapevine. The prison administration knew that incarceration often bred moroseness, indifference, and resentment, but they had no idea that the inmates held the power to translate those emotions into action. Prison matron, Claire Baker, reported that it "...was within the power of the convicts to get any official or guard discharged." ${ }^{139}$ William A. Ekwall, a Judge of the Municipal Court in Salem, blamed the laxity in management for the rising troubles at the prison. Ekwall pointed to Pierce's parole record as evidence of this laxity. ${ }^{40}$ Pierce paroled 555 convicts serving out their sentences in county jails and at the Oregon State Penitentiary. When the inmates came to the realization that they held the balance of power in their own hands, they quickly asserted their strength and rebelled. It was this that led Tom 
Murray and his followers to escape in March of 1924 and again in August of 1925. But now Tom Murray was behind bars once again. The Murray ordeal sparked an intense debate over the course of the prison's future.

Unquestionably, there was something wrong in Salem. "Always a storm of controversy, both as to its policies of restraint and punishment; and as to its management, it has been a menace and a liability to every state administration." ${ }^{41}$ The Murray affair, however, opened up a political can of worms. The magnitude of the crisis was immense.

Stimulated by rumors of laxity in discipline and cowardice, Governor Pierce authorized a full investigation of the crisis. Warden Dalrymple was questioned as to why he retreated into his home when confronted with the escape. His reply was that he went to arm himself sufficiently in case of a gunfight. Guard John Davidson delivered damaging evidence of staff cowardice when he reported to investigators that when Murray broke into the arsenal he had a dagger drawn on Davidson. When Davidson refused to open the arsenal, Murray kicked him in the stomach and a brawl ensued. Neither turnkey Nesmith or guard Peter White did anything to physically restrain the distracted convict. Peter White attempted to relieve blame from himself by pointing out that guard George Hubbard at post number seven had a clear view of the action transpiring, but did not fire a single shot. $^{42}$ The finger-pointing and scape-goating, however, did not solve the crisis. One of those pointing fingers was former Governor Oswald West. West placed the responsibility on the shoulders of Governor Pierce. If Pierce was to 
receive full credit for the financial reform of the prison simply by his authority, then he, too, ought to receive blame for the prison's failures. "Governor Pierce cannot escape responsibility for the prison tragedy," West claimed, "Dalrymple is his appointee. This situation was the cheapest kind of politics." West continued:

Had Governor Pierce been as much concerned in securing a decent prison administration as he was in playing politics he would have made inquiry as to Dalrymple's fitness from those who were in position to enlighten him. He was never fit for a subordinate position, let alone warden. ${ }^{43}$

Dalrymple, West asserted, "was born white-livered and has run true to form. ${ }^{\text {"44 }}$ West's claims to Pierce's responsibility were further substantiated by the testimony of L. Rayburn, a former guard at the prison with twenty years service with the police and the prison. Rayburn was relieved of his duties on July 31 , for no specific reasons other than that Dalrymple disliked him. Rayburn had been informed by a convict two weeks earlier that he was going to be fired and replaced before the end of the month. ${ }^{45}$ Rayburn was replaced with the brother of Dalrymple's wife, James Milton Holman. Holman only served twelve days at the prison before being killed by the escapees. One week after his dismissal, Rayburn visited the governor's residence and informed Pierce that unless discipline was tightened there would be a serious break in the near future. Pierce recalled the visit, but felt unable to act upon this inside information without undermining Dalrymple's authority.

The subsequent investigations compelled five guards to retire, including Leland T. "Pat" Murphy, George Hubbard, and Claire Baker. J.V. Starrett, the 
parole officer, also resigned. Dalrymple was removed and the position of warden opened up to J.W. Lillie. Governor Pierce was intent upon making this a thorough purge as he was unwilling to let the prison ruin his reputation and career. New safeguards were planned including better arsenal protection, a new guard tower, and the installation of a web of high voltage electrical wires above the cells of certain inmates.

Pierce's political problems were solved by the appointment of former Gilliam County Sheriff, J.W. Lillie. As the new warden, Lillie was determined to do his best in restoring order to the Oregon State Penitentiary. Lillie had not only served as sheriff in Gilliam County, but also as deputy warden under both Johnson S. Smith and A.M. Dalrymple. ${ }^{46}$ He was chosen for his stern disciplinarian but compassionate attitude. Lillie had "little difficulty in handling men in that he does not pull that 'big me and little you' attitude, which is so noticeable at times."47 In February of 1926 Lillie received his first major test when a major dining room disturbance rapidly escalated into a major 200 man riot. Guards in an adjoining dining room heard the disturbance in the dining room and rushed to the hall with their loaded firearms. Warden Lillie, one of the first to reach the dining room, fired close to fifteen shots at a group of inmates. Convicts cowered in fear. Albert Corley, a black inmate, was critically injured from the wave of bullets shot through the cafeteria. The riot came to an abrupt halt. ${ }^{48}$

Governor Pierce and Warden Lillie both expressed a belief that the disturbance was as a result of a decrease in pay for employees of the flax mill 
from fifty cents per day to only twenty-five cents a day. Lillie's removal of institutional privileges was a further cause of the riot. The "silence system" was temporarily restored to the dining hall. Lillie prohibited all smoking outside of an inmate's cell. The seven ringleaders of the disturbance were punished with stripes. They were forced to wear the coarse striped uniform instead of their cadet grey uniforms and were also sentenced to the Bullpen. To improve the institution's handling of the inmates Lillie reverted back to a policy previously abandoned in 1914. "In line with his policy of maintaining strict discipline in the prison, Warden Lillie...issued orders that hereafter armed guards shall be stationed in the steel cage suspended from the ceiling of the institution dining room during meal hours." ${ }^{19}$ In order to deter future riots, Lillie announced that damages incurred during the dining hall riot be paid for from the prisoners's entertainment fund. Fully aware of the "humanitarian reformers" outside of the institution, Lillie was prepared to stand his ground. "Appeals from 'sob sisters'," Lillie and Pierce agreed, "will receive little attention."150 Complaints from the sympathetic public fell on deaf ears.

Lillie's strict discipline was needed at the penitentiary. Over the course of the following ten years only thirty-seven escapes took place. This number of escapes is well under the number of escapes that previously occurred during the two and one half year administration of A.M. Dalrymple. ${ }^{51}$ It was obvious that Lillie's firm hand had had a sobering effect upon the inmates. The administrations of H.W. Meyers (1928-1931) and J.W. Lewis (1931-1938) would 
continue the stern handling of the inmates. Meyers, an appointee of Governor I.L. Patterson and Governor A.W. Norblad, maintained a rigid system of privileges and punishments. His successor, J.W. Lewis, an appointee of both governors Julius L. Meier and Charles Martin, proved Lillie's penal theories to be strong and successful.

"In this prison," a convict wrote, "as in others, the inmate falls into what has been aptly named a prison stupor, and simply wants for the sun to do the required number of revolutions of its endless journey."152 The Oregon State Penitentiary's form of discipline and monotonous routine created a drone-like laborer; a manageable and controllable drone-like laborer. The flax mills, as a result, were churning out thousands of dollars worth of the finished product. The monotonous work in the mills was tiring. "All day he would sit on a bale of flax while his aged fingers knotted the ends of rope twine." 53 The inmate writer continued his description of daily life, "In the winter the dust and noise was augmented by the cold, freezing winds that made his gnarled fingers grow so blue and numb that he could not feel the string in his hands. ${ }^{154}$ The work alone did not create the morose zombie-like inmate. The official inmate regulations contributed to this stupor. The inmate rules called for "strict obedience" and instructed each inmate to be "industrious, submissive, and obedient...."55

The administration had learned a hard lesson. Effective discipline was finally in force and the inmates under control. The only obstacle before the prison was the prevention of stagnation. The prison began taking measures to 
prevent this very thing. Under Warden H.W. Meyers, the Administration Building was completed in 1930. Meyers also pointed out to the legislature the need for structural improvements at the prison. The outer wall, he noted, was only fifteen feet high and to minimize future escapes, a wall no less than thirty feet high was needed. He also indicated that there was a "...woeful lack of space for recreation...." ${ }^{156}$ While the number of escapes progressively decreased throughout the 1930 s, the inmate population grew by leaps and bounds. Meyers quickly recognized that the "total housing facilities will be insufficient, as no doubt there will be a continued increase in population as time goes on...." ${ }^{157}$ Warden J.W. Lewis and Deputy Warden Halley were instrumental in the construction of a new cafeteria. The long rows of tables with six settings apiece was abolished for a more individually tailored cafeteria system. It was the intent of the cafeteria's designers to give the inmates a sense of freedom and option, rather than an institutionalized formal dining process.

In order to keep ahead of internal stagnation and to stay abreast of the dramatic social changes accompanying Roosevelt's sweeping New Deal, Warden Meyers prompted reform within the prison. Meyers recommended the employment of a vocational counselor and a psychiatrist at the prison. "The application of a scientist of this order," Meyers said, "is a fundamental proposition and is a development of modern penology. The weak must be made stronger...."188 Education at the prison was also improved. In coordination with Professor W.G. Beattie of the University of Oregon and chapel officer M.W. 
Miller, Warden Lewis initiated a program entitled "Rehabilitation by Better Education. ${ }^{159}$ This program entailed library improvements and educational opportunities within the prison.

The most noteworthy development of this peaceful era was the 1936 inauguration of the award-winning prison newspaper, The Shadows. Hugh DeAutremont, the eldest of the legendary trio of train-robbing brothers, was editor of The Shadows from its beginning in 1936 until its final publication in 1959. The purpose of the newspaper was to give the convicts at the Oregon State Penitentiary an opportunity for self-expression and to "...encourage moral and intellectual improvement among the inmates; and to acquaint the public with the true status of the prisoner." ${ }^{160}$ The Shadows, however, was much more than that. It depicted injustice and offered to its readers the differing perspectives of society. It published news of progressive Texas prison reforms. It editorialized on Roosevelt's New Deal, the passion for freedom, and the criminal mind. It also gave excellent coverage of the prison's internal sports leagues and contests. The slang in The Shadows, however, is so thick that only an astute penal-linguist could decipher it entirely. The magazine often offered a glossary of "slanguage" to aid outsiders in their understanding of the articles. The articles in The Shadows also gave evidence of internal tensions at the penitentiary.

Between 1927 and 1940 the internal tensions at the Oregon State Penitentiary were temporarily stabilized. Over the course of those fourteen years only 44 escapes were recorded. The four years preceding this decade and a half 
of peace (1923-1926) saw twice as many escapes. In 1941, however, as the United States entered the Second World War, tensions in the prison again began to increase. DeAutremont's prison newspaper, The Shadows, began publishing essays highly critical of prison policy. Inmate Ed Bradley in his article, "Prison Fails Itself", wrote, "...present-day prisons are the great retarding influence in the movement by penologists to achieve rehabilitation of law violators. ${ }^{161}$ The prison was often compared to Nazi Germany and Fascist Italy. "The prison-state is a fascistic state," wrote inmate Cyril Staab, "Economic dependency is stressed and encouraged....Class hatred is allowed to grow and regimentation is strictly adhered to."62 Warden George Alexander's harsh disciplinary measures were not producing obedience and conformity, but rather breeding discontent, resentment, and bitterness. Between 1941 and 1951 there were over 160 escapes. Throughout the country during this era resentment in prisons was brewing and the 1950 s saw these feelings erupt. ${ }^{63}$ Oregon was no exception. The riots and strikes of the 1950s ended another tragic cycle in Oregon's prison history and started another cycle anew. 


\section{ENDNOTES}

${ }^{1}$ Oregonian, 29 March 1924, p. 1.

${ }^{2}$ Oregonian, 6 May 1923, p. 6.

${ }^{3}$ Oregonian, 13 August 1925, p. 2.

${ }^{4}$ Ibid.

${ }^{5}$ Ibid.

${ }^{6}$ Oregonian, 15 August 1925, p. 1.

${ }^{7}$ Oregonian, 19 August 1925, p. 1.

${ }^{8}$ Oregonian, 18 August 1925, Extra Edition, p. 1.

${ }^{9}$ Ibid.

${ }^{10}$ Oregonian, 18 August 1925, Second Extra Edition, p. 2.

${ }^{11}$ Oregonian, 22 August 1925, Extra Edition, p. 1.

${ }^{12}$ Ibid.

${ }^{13}$ Lend A Hand, January 1918, p. 7.

${ }^{14}$ Report of the Commission to Investigate the Oregon State Penitentiary, (Portland: 1917), p. 33.

${ }^{15}$ Ibid., p. 74.

${ }^{16}$ Lend A Hand, August 1917, p. 12.

${ }^{17}$ Report of the Commission to Investigate the Oregon State Penitentiary, p. 33.

${ }^{18}$ Gaddis and Long, Killer: A Journal of Murder, p. 95.

${ }^{19}$ Ibid., p. 96.

${ }^{20}$ Ibid., p. 110. 
${ }^{21}$ Report of the Commission to Investigate the Oregon State Penitentiary, p. 1.

$$
\begin{aligned}
& { }^{22} \text { Ibid., p. } 2 . \\
& { }^{23} \text { Ibid., p. } 50 .
\end{aligned}
$$

${ }^{24}$ Problems at the penitentiary under Superintendent Stevens, culminating in a number of riots in early 1919, resulted in Stevens's departure from the institution. Dr. Lee Steiner, the director of the nearby Insane Asylum, was prevailed upon by Governor Ben Olcott to stabilize the prison crisis. Steiner visited a number of prisons throughout the nation and attempted to apply his experience to the Oregon State Penitentiary. After only a year Steiner returned to the sole responsibility of running the asylum. It was Steiner's suggestion, however, that a ward for the criminally insane be constructed at the asylum to protect the general insane and general criminal population. Steiner's categorization of criminals along these lines is another example of the new penal policy of individualized treatment. See, O. Larsell, "History of Care of Insane in the State of Oregon", Oregon Historical Quarterly,vol.XLVI, December 1945,pp.295-326.

${ }^{25}$ Lend A Hand, March 1923, p. 24.

${ }^{26}$ Arthur Bone,ed., Oregon Cattleman, Governor, Congressman: Memoirs and Times of Walter M. Pierce,(Portland: Oregon Historical Society, 1981), p. 260.

${ }^{27}$ Oregonian, 9 August 1923, p. 4.

${ }^{28}$ Lend A Hand, December 1923, p. 5.

${ }^{29}$ Bone, Oregon Cattleman, Governor, Congressman, p. 105.

${ }^{30}$ Ibid.

${ }^{31}$ Oregonian, 16 August 1925, p. 6.

${ }^{32}$ Oregonian, 14 August 1925, p. 10.

${ }^{33}$ Oregonian, 16 August 1925, p. 14.

${ }^{34}$ Bone, p. 260.

${ }^{35}$ Ibid., p. 312.

${ }^{36}$ Oregonian, 19 August 1925, p. 8.

${ }^{37}$ Ibid. 
${ }^{38}$ Oregonian, 14 August 1925, p. 8.

${ }^{39}$ Oregonian, 19 August 1925, p. 8.

${ }^{40}$ Oregonian, 21 August 1925, p. 10.

${ }^{41}$ Oregonian, 14 August 1925, p. 10.

${ }^{42}$ Oregonian, 18 August 1925, p. 3.

${ }^{43}$ Oregonian, 14 August 1925, p. 8.

${ }^{44}$ Ibid.

${ }^{45}$ Ibid.

${ }^{46}$ Lend A Hand, December 1923, p. 7.

${ }^{47}$ Ibid.

${ }^{48}$ Oregonian, 17 February 1926, p. 4.

${ }^{49}$ Oregonian, 18 February 1926, p. 8.

${ }^{50}$ Ibid.

${ }^{51}$ Inmate Escapes, 1866-1938:

\begin{tabular}{||l|l|l|l|l|l|l||}
\hline $1866-12$ & $1877-0$ & $1888-0$ & $1899-4$ & $1911-14$ & $1922-1$ & $1933-3$ \\
\hline $1867-0$ & $1878-4$ & $1889-0$ & $1900-1$ & $1912-51$ & $1923-50$ & $1934-6$ \\
\hline $1868-1$ & $1879-2$ & $1890-2$ & $1901-0$ & $1913-29$ & $1924-26$ & $1935-3$ \\
\hline $1869-2$ & $1880-4$ & $1891-1$ & $1902-2$ & $1914-19$ & $1925-14$ & $1936-1$ \\
\hline $1870-7$ & $1881-6$ & $1892-3$ & $1903-4$ & $1915-13$ & $1926-11$ & $1937-5$ \\
\hline $1871-4$ & $1882-7$ & $1893-0$ & $1905-3$ & $1916-22$ & $1927-2$ & $1938-0$ \\
\hline $1872-0$ & $1883-11$ & $1894-0$ & $1906-7$ & $1917-30$ & $1928-2$ & \\
\hline $1873-0$ & $1884-4$ & $1895-3$ & $1907-10$ & $1918-28$ & $1929-0$ & \\
\hline $1874-1$ & $1885-0$ & $1896-6$ & $1908-16$ & $1919-9$ & $1930-4$ & \\
\hline $1875-1$ & $1886-2$ & $1897-2$ & $1909-30$ & $1920-16$ & $1931-6$ & \\
\hline $1876-0$ & $1887-1$ & $1898-2$ & $1910-9$ & $1921-5$ & $1932-5$ & \\
\hline \hline
\end{tabular}

-compiled from the Oregon State Penitentiary escape records. 
${ }^{52}$ The Shadows, Oregon State Penitentiary magazine, July 1936, p. 15.

${ }^{53}$ The Shadows, January-February 1936, p. 5.

${ }^{54}$ Ibid., p. 4.

55" General Rules for the Inmates of the Oregon State Penitentiary", January 1, 1928. Unpublished.

${ }^{56}$ Fifteenth Biennial Report of the Penitentiary, 1930, p. 3.

${ }^{57}$ Ibid.

${ }^{58}$ Ibid., p. 8.

${ }^{59}$ The Shadows, April 1936, p. 5.

${ }^{60}$ The Shadows, January-February 1936, p. 12.

${ }^{61}$ The Shadows, August 1941, p. 3.

${ }^{62}$ The Shadows, November 1941, p. 3.

${ }^{63}$ Vernon Fox, Violence Behind Bars: An Explosive Report on Prison Riots in the United States, (Westport, CT: Greenwood Press, 1956); for additional reading on prison violence see Bert Useem and Peter Kimball, States of Siege: U.S Prison Riots, 1971-1986, (New York: Oxford University Press, 1989). 


\section{CHAPTER VII}

\section{"THE GRAVEYARD OF WARDENS": 1939-1953}

By the summer of 1951, crises within America's prisons were reaching immense proportions. Hundreds of riots throughout the country alarmed the general public. They were, as Bert Useem and Peter Kimball later remarked, "states of siege."1

To stem the potential for problems in Oregon, the 1951 legislature took steps to improve the penitentiary's conditions. The legislature approved of a Tillamook Burn Area convict camp. The legislature also called for the removal of Warden George Alexander. The prison air was thick with discontent and disgust. The atmosphere was filled with a "...deteriorated administration morale." ${ }^{2}$ The Oregonian headlines of August 15, 1951, told of the ending of the Utah State Penitentiary riot. On that same day over one thousand convicts at the Oregon State Penitentiary engaged in a sit-down strike after a scuffle between two inmates and an attack by a prison guard. Inmates Steve Minor and Newton Compton, both serving life sentences for second degree murder, were spread out on the floor in a brawl. Guard Maurice Folquet attempted to end the conflict through the liberal use of his billy club. Folquet then became entangled in the messy brawl. Guard Captain Morris Race pulled convict Steve Minor off guard Folquet 
and restored order. Shortly thereafter, the inmates began their sit-down strike.

Race initially suspected that the strike was as a result of agitation from the denial of a pay increase from twenty-five cents a day to one dollar. ${ }^{3}$

Prison industries came to a dramatic and abrupt halt because of the strike, but no violence occurred and all meals were taken as usual. Inmate Ted Audett, chairman of the Inmates Council, claimed Guard Captain Race had been brutal in the past and had stirred up agitation by taunting inmates, and therefore the council requested his removal. ${ }^{4}$ Alexander, naturally, disagreed. "The next thing you'd know," he said, "they'd want someone else transferred. You might as well turn the place over to the convicts as let them get away with that."5

The administration quickly recognized that the strike was being exploited as a means to pressure the warden and weaken discipline and push for the warden's removal. "We are not being fooled by any clever plan the prisoners may have in mind, however," the administration responded, "and every precaution is being taken to prevent any serious disturbance within the institution's walls."6

For the moment the prison authorities were willing to let the strike take its due course. No disciplinary measures were initially planned for the strikers. But Alexander made a dramatic change of course when he announced that the striking prisoners would not be fed until they returned to work and ended their sit-down strike. After missing lunch and dinner on the striker's second day, the inmates voted, approximately seven hundred to one hundred, not to return to work. Two inmates, released from the prison during the riot after having served their 
prescribed time, told reporters that the striking inmates were surviving on a broth of salt and pepper and a syrup of sugar and water. ${ }^{7}$

Warden Alexander then eliminated all newspaper and radio access to the inmates. Despite the severing of contact with the outside world, rumors began circulating through the prison grapevine. State Senator Douglas Yeater of Salem criticized the Board of Control for their failure to replace Alexander as requested by the previous legislature. Yeater then initiated an investigatory probe into the prison crisis. His probe proposal reached the inmates's ears and it was feared that the proposal might delay a strike settlement. The convicts and the administration, however, were already in a firm deadlock. Time, however, was on the side of the administration. The Fellowship of Reconciliation of Portland protested Alexander's policies. That same day, forty inmates buckled to their own hunger and returned to work in order to eat. The strike was in its sixth day.

Former Governor Oswald West offered to take the reins at the prison and guaranteed his audience that he would have everything under complete control within three months. Thomas Lawson McCall, Governor Douglas McKay's administrative assistant and President of the Oregon Prison Association, was alarmed by the prison crisis. James V. Bennett, Director of the Federal Bureau of Prisons, in correspondence with McCall, wrote: "I don't think I would legalize inmate representation, but I do have great faith in the establishment of committees to bring inmates into the operation of the prison. ${ }^{.8}$ Warden George Alexander, despite his consultation with McCall, subsequently abolished the eight- 
man inmate council, thus bringing to an end Oregon's experiment in penal democracy.

Democracy was not the only thing killed at the penitentiary. The Board of Control suggested remedies to the sit-down strike. They proposed a system of uniformly consistent discipline, an investigation of brutality charges, and a completion of the selection of a new warden. Furthermore, Warden George Alexander was to be removed from office.

Alexander had simply stayed on too long as warden. His policies were outdated, inefficient, and stagnant. His charismatic leadership of the institution had served the prison early in his term, but now at its closure it seemed apparent that Alexander had failed to keep abreast with modern penal thought and current social trends. It was a fine line to walk for a warden or superintendent. He could serve four years and achieve nothing or he could serve twenty (with political blessing) and risk ruining all that he had achieved. Alexander knew the risks, but fell prey to the latter anyway. The convicts's demand for Alexander's removal was granted.

The sit-down strike rapidly dissipated and dissolved. "Quiet as a tomb," was the way Deputy Warden Eugene Halley described the prison. ${ }^{9}$ Warden Alexander emptied his desk drawers and packed his bags. The Oregon State Penitentiary was quickly becoming known as the "graveyard of wardens."10 The Board of Control attempted to salvage George Alexander and his reputation by creating a superintendent's position that would be subordinate to 
the warden. Alexander also served as President of the American Prison Association during this time. In September of 1951, Virgil O'Malley stepped onto the grounds of the Oregon State Penitentiary as the new warden. He cultivated from the state legislature new funding and lobbied for improved disciplinary procedures and structures.

Two months later on November 4, 1951, inmate John Omar Pinson, a murderer and renowned escape artist, assaulted two guards and held them at gunpoint. The two guards were ordered into the lock control cage and then later into a pipe tunnel. The guards immediately began crawling toward the upper tier with the hope of escaping and warning the guards there. In the tunnel, however, they were met by Officer Dennis Knight, who had been placed in the tunnel from the fourth tier and was moving down to warn them. Pinson was joined by nine other inmates, anxious to exploit the new opportunity. ${ }^{11}$ Among the nine inmates was John Edward Ralph and Dupree Poe, two of the prison's most notorious convicts. As members of the abolished convict committee, Ralph and Poe were highly vocal.

Poe was serving a life sentence for the murder of a Silverton, Oregon, police officer in 1931. He wrote numerous articles and editorials for The Shadows magazine throughout the 1930 s and 1940s. In an article entitled "The Motivating Force" Poe wrote, "I perceived the world with impressionability and vividness, incited by child-like wonder that was unchained to cultivated logic; for I gazed through the eye of a madman, unblinded by sanity."12 Sanity was not in sight on 
this Thursday evening. The convicts were within fifty feet of freedom when Guard Maurice Folquet spotted them. "Come on you fellows and get the hell back in here," Folquet shouted, unaware that it was an attempted escape. ${ }^{13}$ The inmates meekly returned to their cells. The attempted escapees were sentenced to temporary isolation. Shortly thereafter it was announced that a segregation unit would be installed. O'Malley took measures to stem the tide of unrest, but his position was already in jeopardy.

Among those measures taken to stem the tide of escapes was O'Malley's cultivation of the friendship of inmate John Edward Ralph. Ralph had been a ringleader in the prison, but a change of heart convinced him to turn "snitch." Only one month after his own attempted escape, Ralph exposed an escape plot. Ralph laid bare the work of Guard Francis L. McConnell who had secretly given dynamite, a revolver, and ammunition to Dupree Poe. ${ }^{14}$ Poe, despite his writing success, was always denied parole. He was intent, however, on getting out from behind the thick grey walls. His correspondence with Claire Argow, the Oregon Prison Association executive secretary, shows a desperate plea for assistance. He also attempted to file for national repatriation. Poe claimed he was born in northeast China, not Texas, and therefore was eligible for repatriation to communist China under a 1955 treaty with that nation. Poe's claims were consistently denied. ${ }^{15}$ The prison's problems were further exposed by the escape of Lawson David Shirk Butler. The escape of the "lone wolf" on February 8, 1952, placed Butler on the FBI's top ten list of most wanted criminals. Butler had 
served two sentences at San Quentin, and at the Oregon State Penitentiary was placed twice in the "hole" for attempted escape. Butler's nationwide reputation placed Oregon's prison under great scrutiny. ${ }^{16}$ Resentment and death threats issued to Ralph resulted in Ralph's transfer to Folsom Prison in California.

In November of 1952 , the inmates at the penitentiary rose again in rebellion. Sixteen convicts, all inmates in the new segregation unit, staged a twenty-nine hour hunger strike. The strike was reported to be over food served at two meals. Apparently macaroni and cheese was served at both lunch and dinner rather than the traditional side dish of potatoes. Deputy Warden Lawrence O'Brien said it was simply a mistake in food ordering. The inmates, however, were not happy. In a search of the inmate's cells, two knives were found in the cells of Death Row inmates Morris Leland and Frank Payne. O’Brien used this finding as a pretense for using force in returning the convicts to their cells. "It looks as though we might have to starve them out," O’Brien said. ${ }^{17}$ An electric "frisker" was used to shake down the strike and the protesting inmates. The strike was quickly quelled.

Three months later, on February 9, 1953, tensions again hit a boiling point. At six-thirty that night guards entered the segregation unit to feed the convicts. An angry mob of inmates ambushed the guards and held the five men hostage and threatened to slit their throats. The convicts demanded and received promises from authorities for definite sentences in the segregation cell block. Negotiating for the convicts was inmate Dupree "Buck" Poe. Again, this disturbance 
dissolved. ${ }^{18}$ Governor Paul Patterson, fully aware of the public unrest regarding the prison crisis, issued a statement declaring that new regulations would be put into effect "...to make sure all convicts are in their cells hereafter before any food is wheeled into the segregation corridor...." ${ }^{19}$ The following Monday, General Charles Brandon Booth, Commander in Chief of the Volunteers of America, spoke on the crisis within America's prisons. In his Portland speech he said, "It's not the quality of the coffee that sparks prison riots; its the 'iniquitous public apathy' toward the whole program of punishment and rehabilitation...."20 Twenty serious prison riots in the United States in the last ten months had caused serious alarm nationwide.

Control at the Oregon State Penitentiary quickly evolved into an exercise of deprivation. The prison was full of sex-starved, oppressed, frustrated, and emotionally defeated men. The prison, in turn, shaped its administrators. George Alexander had been the assistant superintendent of state police, sheriff of Washington County, and the state's prohibition enforcement officer. In 1938, however, he donned the title of Warden of the Oregon State Penitentiary. The prison state took form under Alexander's tenure of office. An anonymous writer in The Shadows magazine wrote:

Castellated walls tower up and shadow into sinister oblivion a thousand empty lives. Each brick in the wall might scream out the anguish of a futile dream exploded. Beyond the wall is light and all within gloom. With future freedom a star of hope on the horizon of life, convicts pace up and down the exercise yard.... ${ }^{21}$ 
It was becoming painfully obvious that despite the administrator's wellintended efforts, the prison was again slipping into stagnation.

The deplorable conditions were magnified by the public release of conditions on the prison's "nut row."22 Roy DeAutremont, one of the trainrobbing brothers in his twenty-second year behind bars, was unable to adjust to his eternal confinement. He slowly turned morose and argumentative and by autumn 1949, Roy went "berserk", virtually destroying the interior of his cell."23 Roy's deterioration did not alarm any of the prison's authorities until he had simply become unmanageable. "Babbling incoherently, laughing when he was told someone had died or was sick, crying when informed of good news...," all of Roy DeAutremont's reactions were twisted. ${ }^{24}$ When a reporter visited his cell they found him "...pacing his barren cell stark naked, like the animal he has become." 25 Doctors later diagnosed him as schizophrenic and transferred him to the state hospital for the insane. Shortly thereafter, Roy was given a prefontal lobotomy operation. ${ }^{26} \quad$ The pain of twenty-two years behind the walls had simply grown to be unbearable. Severing all connection with reality was his only escape.

While inmates typically despised the superintendent or warden, they generally realized the real problem rested in the penal structure as a whole. "Do not blame the prison executives for this deplorable condition;" an inmate wrote, "it isn't their fault. They recognize the failure of the system, but like all gargantuan enterprises of man, it has outgrown their power to do anything about it."127 
Conditions at the prison had indeed grown out of control. Last-ditch efforts at reform by the legislature proved futile. The 1939 legislature established a State Board of Parole and Probation. The Board would simply be another piece to the confusing and complex puzzle. Paul R. Kelty, Chairman of the Board of Parole and Probation, declared the goals of the committee to rehabilitate, protect, and financially guide the prison. The "Gargantuan enterpise", however, was already beyond the power of the board.

It was at this juncture that Oregon penologists began to fairly assess the crisis. Present-day prisons, they said, are a "great retarding influence in the movement by penologists to achieve rehabilitation of law violators. ${ }^{128}$ They further recognized that the criminal was not born, but made. They continued, "He is no different from you, except his vices are exaggerated. Society is largely responsible for this making-society embodied in the parents, the teachers, neighbors and the great mass of the people....."29 Penologists recognized the inherent pathologies within the penal system. But how to resolve the crisis and begin anew? An anonymous inmate said of the system, "Y'know, kid, this present atrocity they call the modern penological system is the prize flopperoo of the age. ${ }^{130}$

The unrest at the prison, including the publicity surrounding the "nut row", helped contribute to the formation of the prison's first inmate council in 1951. The council was to facilitate a closer understanding between inmates and administration. In part, stimulated by Thomas Mott Osborne's "Mutual Welfare 
League", the inmate council was believed to have a natural inclination toward selfdiscipline. Any measure to promote discipline and inmate happiness was readily adopted. Six councilmen and two alternatives were elected. Lawson Butler and Ted Audett were the leaders of the council. In their June 1951 meeting they made five requests. Three of their requests were sanitary in nature, while the other two were for more humane treatment. ${ }^{31}$ The inmates requested more clean sheets, more soap in the bathroom, and that kitchen employees be allowed clean clothing daily. They also requested the practice of head shaving upon entrance into the prison be eliminated. In addition, they asked for employment service assistance upon release.

In the subsequent weeks they filed more requests and a list of grievances. By the end of July, 1951, Warden Alexander met with the inmate council and approved clean blankets and plumbing in the Bullpen; legalized chess, checkers, and dominoes; and agreed to discuss with the staff doctor about a special diet line at the cafeteria. As to other requests, Alexander simply stated that he would investigate further into the matters. Alexander's capitulation was not fast enough. Inmates of the 1950s were well aware of the post-war economic boom. The 1950s was an era of good feeling and economic prosperity and yet the men behind bars were still being subjected to "medieval-like" conditions. The administrators had maintained control, but they had not kept abreast of modern social developments. Again, there was change without change. Alexander's administration saw many technological advancements, but his policies never addressed the problems of the 
period. Nor were they effective in stemming prison disorder.

After the critical early 1950 s, however, it was painfully obvious that prisons were in serious danger. Violence, overcrowding, racial tension, and social reforming forces were problematic issues for penologists and prison administrators. These were issues to be dealt with by the Oregon State Penitentiary's new warden, Virgil O’Malley.

O'Malley's problems were far beyond food ordering mistakes. He was rapidly becoming a political liability because to the public he appeared to be soft. In mid-March 1953, Joseph Poggi, an inmate convicted in 1928 for the theft of a pipe, brought his story to the public's attention. After twenty years in prison Poggi was still certain he could get out on parole if the right tactics were employed, and when O'Malley assumed control of the prison, Poggi had hope. O'Malley allowed Poggi to consult with an attorney. That month Poggi was released and the public became painfully aware of O'Malley's leniency. ${ }^{32}$

It was at this juncture that the Oregon Board of Control stepped in and began to take control of the prison crisis. Their remedy was not so much to address the crisis, but to remove the man attempting to resolve the crisis. The board requested from the Warden's Association of America that a non-partisan three-man committee come to Oregon and investigate the prison situation. The "gargantuan enterprise" was to be tackled now through outside forces. The threeman committee arrived on Sunday, March 15, 1953, and left the following Wednesday. In those few days Wardens Joseph Ragen of Joliet, Illinois; L.E. 
Clapp of Boise, Idaho; and G. Norton Jameson of Sioux City, South Dakota inspected the grounds, inspected the records, interviewed staff and inmates and filed a report. ${ }^{33}$

In their report they claimed that the institution might "...burst into flaming revolt at almost any moment....."134 They reported a general ignorance as to prison policy, evidence of handmade guns and knives, and rampant homosexuality. Younger inmates, they stated, were afraid to file for parole due to threats issued from older convicts with whom they were having a "love affair." Coinciding with these findings the committee reported of over twenty-five beatings of guards in 1952 alone. These beatings, coupled with low wages, helped give the Oregon State Penitentiary a ninety-one percent staff turnover. ${ }^{35}$

Prison guards who are responsible for the safety and security of others build up a sensitivity to danger cues. Through this, guards might be unwittingly trained to feel vulnerable and unprotected. The twenty-five beatings in 1952 heightened the tension in the prison's guards and forced them to act in ways they would not have ordinarily acted had they felt safe in their work environment. Throughout the nation, Hans Toch states, "Police, prison staff, and inmates...tend to spring disproportionately from working-class backgrounds, and they are accustomed to regard physical prowess (and willingness to fight) as measures of manly worth." (emphasis Toch's) ${ }^{36}$ This also may be the case in Oregon. The guards at the Oregon State Penitentiary did indeed respond in physical ways. They flexed their muscles, rolled up their sleeves, and bore down on the inmates 
with billy clubs and fists. If the inmates would not voluntarily submit, they would be forced to. The primordial thirst for revenge was never fully satiated. The guards attacked the inmates, but blamed O'Malley for undermining their authority. As a result, the warden never received or commanded the loyal support of his guards.

The three-man committee made several recommendations. Its first recommendation was to immediately hire a "competent warden"37 They further suggested that "all inmates be locked in cells and fed there until, by a weeding process, control and discipline can be restored." ${ }^{138}$ The committee criticized the dual leadership of O’Malley and Alexander. "We are, however, of the opinion that this dual leadership of the institution is definitely bad and will not work for any extended period." ${ }^{139}$ O'Malley suffered from the committee's policy. Senator Richard Neuberger later stated that the "...retention of Superintendent Alexander was a face-saving device, which doomed O’Malley's administration."40 The penal triumvirate (the Board of Control, the Superintendent, and the Warden) divided the authority over the prison in such a way as to render each part impotent. The Board of Control was composed of Governor Patterson, Secretary of State Earl Newbry, and State Treasurer Sig Unander. These individuals had a vast array of responsibilities to deal with let alone their primary elected duties.

O'Malley repelled the criticism shot at him by stating, "I was forced to work with George Alexander whose philosophy was in direct opposition to mine"41 He criticized the three-man commission for its brief investigation and 
suggested that the report be addressed to Alexander who wielded the real power at the institution. O'Malley was shocked by his sudden removal, but was fully cognizant of the fact that he was in an impossible situation when he took the job.

The dismissal of Virgil O'Malley by the Board of Control points to inherent weaknesses within the structure. The Borad of Control to account for external forces and tended to treat each administration alike. O'Malley's governing of the institution was reform-conscious and relatively stable. The Board of Control, however, was not satisfied with O'Malley's progress and dismissed him. The problem, however, did not rest in O'Malley's leadership, but in the institution's absence of vision, principle, and practice.

The Oregon Prison Association criticized the Board of Control's handling of O'Malley's dismissal. In the April 12 issue of the Oregon Statesman, O’Malley claimed that the three-man committee was unfit to file a recommendation according to OPA standards because it was unfamiliar with the Oregon State Penitentiary and its recent progress. Its progress, however, was temporarily halted as the "graveyard of wardens" consumed another victim, Virgil O'Malley. "The face and reputation of O’Malley were not saved," Senator Neuberger said, "because he has no political connections with the party and faction which have run Oregon politics for many decades...." ${ }^{42}$ While O’Malley's dismissal was a personal loss, it stimulated enough debate and uproar to prompt the State Senate to abolish George Alexander's superintendent position. Neuberger would further suggest that the Board of Control also be abolished and the power placed in the hands of the governor. It was obvious that a new structure was in order. 


\section{ENDNOTES}

${ }^{1}$ Useem and Kimball, States of Siege; see also Vernon Fox's Violence Behind Bars for his coverage of the Michigan prison riots of the 1950s.

${ }^{2}$ Oregonian, 16 August 1951, p. 12.

${ }^{3}$ Oregonian, 21 August 1951, p. 1.

${ }^{4}$ Oregonian, 16 August 1951, p. 1.

${ }^{5}$ Ibid.

${ }^{6}$ Oregonian, 19 August 1951, p. 1.

${ }^{7}$ Oregonian, 21 August 1951, p. 1.

${ }^{8}$ Oregonian, 17 August 1951, p. 1.

9 Oregonian, 19 August 1951, p. 1.

${ }^{10}$ Oregonian, 11 March 1968, p. 27.

${ }^{11}$ From the file of John Omar Pinson, Papers of the Oregon Prison Association, Oregon Historical Society, MSS-1495-1.

${ }^{12}$ The Shadows, November 1940, p. 10.

${ }^{13}$ Oregonian, 1 November 1951, p. 1.

${ }^{14}$ Oregonian, 18 December 1951, p. 1.

${ }^{15}$ Capitol Journal, 2 March 1958, p. 1., and file of Dupree Poe, Papers of the Oregon Prison Association, Oregon Historical Society, MSS-1495-1.

${ }^{16}$ Oregonian, 27 March 1953, p. 6.

${ }^{17}$ Oregonian, 1 November 1952, p. 1.

${ }^{18}$ Ibid.

${ }^{19}$ Oregonian, 11 February 1953, p. 1.

${ }^{20}$ Oregonian, 10 February 1953, p. 7.

${ }^{21}$ The Shadows, December 1940, p. 3.

${ }^{22}$ Oregon Journal, special series, 10 August 1949, p. 1. 
${ }^{23}$ Art Chipman, Tunnel 13, (Medford: Pine Cone Publishers, 1977), p. 132.

${ }^{24}$ John Howard and Larry Sturholm, All for Nothing: The True Story of the Last Great American Train Robbery, (Portland: BLS Publishing Co., 1976), p. 181.

${ }^{25}$ Oregon Journal, special series, 10 August 1949, p. 1.

${ }^{26}$ Schizophrenia, despite its negative connotations, is not necessarily an insane reaction. In fact, the disintegration of the personality is a common technique for pain avoidance.

${ }^{27}$ The Shadows, December 1940, p. 5.

${ }^{28}$ The Shadows, August 1941, p. 3.

${ }^{29}$ The Shadows, December 1939, pp. 18-19.

${ }^{30}$ The Shadows, September 1939, p. 10.

${ }^{31}$ The Shadows, July 1951, pp. 4-5.

${ }^{32}$ Oregonian, 20 March 1953, p. 15.

${ }^{33}$ Oregonian, 1 April 1953, p. 1.

${ }^{34}$ Oregonian, 2 April 1953, p. 10.

${ }^{35}$ Ibid.

${ }^{36} \mathrm{Hans}$ Toch, Police, Prisons, and the Problem of Violence, (Rockville,MD: National Institute of Mental Health Center for Studies of Crime and Delinquency, 1977, and U.S. Department of Health, Education, and Welfare), p. 7.

${ }^{37}$ Oregonian, 1 April 1953, p. 1.

${ }^{38}$ Ibid.

${ }^{39}$ Ibid., p. 10.

${ }^{40}$ Oregon Statesman, 3 April 1953, p. 1.

${ }^{41}$ Oregon Statesman, 12 April 1953, p. 1.

${ }^{42}$ Oregonian, 3 April 1953, p. 21. 


\section{CHAPTER VIII}

\section{"EVERY MAN REACHES HIS BREAKING POINT": 1954-1968}

The prison's new rehabilitative order arose in an era of new social order. The tardy recognition of racial, national, and religious identities in the United States gave impetus to the social revolution of the 1960s. The election of a young Massachussetts senator to the presidency initiated a decade of social reform and dramatic change. John F Kennedy's "New Frontier" and Lyndon Johnson's "Great Society" envisioned an egalitarian America. Robert Kennedy, Martin Luther King,Jr., Malcolm X, Cesar Chavez, Tom Hayden, and Eldridge Cleaver saw a country alive with upheaval; a country amid a social metamorphosis. The United States was in a process of growing liberalization, tolerance, receptiveness, and impartiality. There would naturally be growing pains, however, during this era of social transformation. Those individuals pressed to the margins of society rebelled and confronted their "oppressors." Blacks marched through the South and students protested the war in Vietnam. The civil rights movement was a catalyst for the rise in self-consciousness of these marginal social groups. Prisoners were among these groups. A new structure arose out of this new era and new order.

Oregon was not unaffected throughout this period of social upheaval and reform. Virgil O'Malley's successor as warden, Clarence Gladden, inherited the 
burden of adjusting his institution to the social drama beyond the prison's walls. Gladden had formerly served as warden of federal prisons at Terre Haute, Indiana; McNeil Island, Washington; and Leavenworth, Kansas. Gladden came out of retirement to accept the temporary position in Salem and agreed to initiate a total reformation of the prison. ${ }^{1}$ He would attempt to do so by adopting new programs and following a more therapeutic philosophy of punishment.

The prison crisis in Oregon was not so easily solved, however. Only two weeks after Gladden's arrival the prison erupted into another chaotic upheaval. The prison echoed with cheers as five convicts escaped. Gladden's immediate recapture of four of the escapees signalled to the other convicts that the institution was no longer a "boarding house", but a prison. In July of that same year the convicts tested Gladden again. Over one thousand convicts staged a sitdown strike. The prison's guards prepared for battle. They armed themselves with gas grenades, rifles, and baseball bats. Warden Gladden set an 8 p.m. deadline for the inmates to return to their cells. Shortly after the deadline, convicts Alex Popeko and Dupree Poe met with Warden Gladden. The prisoner complaints were specific. They complained of insufficient food and begged for the removal of hospital technician L.R. Chandler. They also requested that no more indefinite sentences for violation of prison rules be issued and suggested the lifting of a ban on smoking in isolation. Gladden further claimed that the "...convicts were demanding medicine for two sick convicts among others who were in the hospital. However, he refused to send in medicine on the grounds that it was an 
attempt to get hostages."2

The convicts were outraged at Gladden's refusal. On the eleventh of July, they wrecked the commissary and burned down a two-story laundry building. In a "concerted" assault on the control room, one convict was shot in the leg. "They don't appreciate good treatment," Gladden told reporters, "they're getting ugly. They act as though they haven't had enough."'3 On the contrary, however, enough was enough for the majority of the inmates. A three-man inmate committee, including former state legislator R.H.C. Bennett of Newberg, met once again with Gladden. This time the committee capitulated and agreed to return to their cells. When the guards began escorting them back, however, trouble rang out again. Young convicts cried, "Let's knock those state police off the walls and get those police bums out of here." ${ }^{4}$ Hurling foul language at prison staff members is often the only remaining tool a convict possesses to protect his sense of manhood. The language, however, often incites further vengeance and violence. There was no violence, however, on this day, only a shaking of a fist to the sky. Then as the strike dissipated the emotions shifted to resignation and indifference. The internal composition of the prison was changing. Of the one hundred and twenty inmates at the center of the disturbance over eighty percent were thirty years old and younger. ${ }^{5}$ The movement of a large Black population into Oregon during the Second World War and after also seriously transformed the population composition of the state. This racial transformation was also felt in the prison. The direction of the prison's future was altered. 
Not only would policy have to be adjusted, but the financial burden of the institution also needed to be reconsidered. In the biennial period of 1965-1966, the expenditures at the prison was around six and one-half million dollars, while maintaining almost 1500 inmates. It was estimated that between 1967 and 1968, the cost of running the prison, largely because of technological advancements and new rehabilitation programs, would escalate to over eight million dollars, while the number of inmates dwindled down to 1400 . Both trends were expected to continue long after $1968 .^{6}$

In addition to economic pressure, the dynamic social forces outside the prison created a tremendous impact on the prison. Because Oregon only had one adult correctional facility, it lacked the flexibility to properly isolate hard-core inmates within its own system. A segregation unit was, therefore, a necessity. Gladden, it was announced, would be kept on as warden until the construction of the unit was completed. Gladden immediately announced that he planned to institute progressive penal programs like education, recreation, and social work. Gladden's progressive stance was supported by the Oregon Prison Association. Claire Argow, the OPA leader and Chairman of the Corrections Division Advisory Board, set forth the association's aims. They were to improve juvenile facilities, establish special juvenile courts, provide parole and probation services to adults, have facilities set to federal standards, promote indeterminate sentencing and nonvindictive attitudes, and create a Youth Correction Authority. "Prisoners are not sent to prison to be punished," the OPA claimed, "but to be helped."7 
The penitentiary was successful in initiating many new reforms and programs. The prison hired ten additional guards, a hospital technician, and a clerk. The prison, however, was not perfectly adjusted to America's new way of thinking about penology. The 1960s saw a dramatic transformation from disciplinary (or retributive) punishment philosophy to a therapeutic (or rehabilitative) punishment philosophy. Structurally, the institution and penal field also underwent a dramatic metamorphosis under Warden Gladden's leadership. In 1957, the Oregon State Correctional Institution was created and two years later, its doors were opened to Oregon's deviant and dependent classes. In 1965, the Oregon Women's Correctional Center was opened with Gladden as its temporary leader. It became a separate unit in July of 1971 , under the direction of Genevieve V. Calloway. ${ }^{8}$ On July 1,1965 , the Oregon Department of Corrections was established as a division under the Oregon Board of Control. The Department of Corrections's new administrator in October of that year was George W. Randall. He would only serve four months short of three years.

Clarence Gladden began the slow process of transforming the institution. He was supportive of Upward Bound, work release, and other rehabilitative programs. It appeared as if Gladden was fully adopting the therapeutic punishment philosophy and placing it into practice. The Advisory Board to the prison felt so strongly that, in order to effectively judge the institution's programs, research was extremely important. Financial pressures, however, restricted research and development. 
Progressive liberal forces throughout the country became apparent in Oregon when on the third of November, 1964, the voters of the state abolished the death penalty. Governor Robert Holmes (1955-1959) had been personally opposed to the sentence and led the crusade against it. It was not until five years after his term of office, however, that the penalty was abolished. Even Warden Gladden held reservations as to the death penalty. Gladden, throughout his long career in corrections field, observed that, "Only the poor people get executed. The wealthy never are."

Changes, however, were not being made fast enough. In a report to the Corrections Division Advisory Board, Randall spoke of his concern about conditions at the prison. He spoke of "...three cases of suicide, contraband (marijuana and shotgun shells), the attempted mass escape last fall, etc. He commented that all of this indicates there is too much pressure building up at the penitentiary, and that it is necessary that changes be made soon."

Throughout the 1940s, the prison had been maintained by the firm hand of George Alexander. It was the strict leadership of one man that enabled effective control. Clarence Gladden for many years repeated this same single-handed domination. However, in 1965, with the direction of the Board of Control, authority within the prison was fragmented. To assist the Board of Control in supervising the institution, the position of Director of Corrections was created in 1965. The director had the general power to supervise the management of all penal institutions in the state. George Washington Randall, however, was not 
qualified to operate a prison. In 1966, a conflict arose between the Director of Corrections and the warden as to the person in authority. The prison under Gladden's leadership was secure, well-operated, progressive, and consistently rated superior by Federal Prison Inspectors. George Randall, once chosen as Director of Corrections, pursued a policy that "undermined" Warden Gladden's programs. "New programs were forced upon the warden which he was required to approve."10 Inmate and administrative morale sank to an all-time low. When Gladden fell ill in early 1968 , the gap between the two powers was widened. Unrest began to ferment behind the prison's walls.

Recent suicides at the prison contributed to the unrest. There was a total of three suicides within a one month span. On February 2, 1968, convict John T. Snipes hung himself; eleven days later on February 13, 1968, Doyle Duane Trapp committed suicide by "self-inflicted slash wounds;" and less than one month later inmate James Archie Perry killed himself. In each case, investigators found that the deaths were suicides, "no foul play", and no narcotics involved. Each inmate was despondent for his own personal reason. ${ }^{11}$ "Neither the inmates nor the public was properly informed about the causes of death or the extensive investigations into those deaths."12 As a result, both the public and prisoners relied on hearsay and rumor. The crisis was beginning to grow out of control.

Gladden's progressive work release program was also a contributing factor to the prison unrest. The program, initiated shortly after Randall's installation as Director of Corrections, was structured to serve "as a midpoint in the prisoner's 
eventual release from custody."13 After his acceptance into the program, the inmate received help in locating appropriate job openings outside the penitentiary. He then began work at the site. He was returned to the prison when not working. Over four hundred inmates participated in the program between 1965 and 1968. Those inmates first selected were the administrative office helpers. Those selected into the program caused animosity and resentment among the remaining inmates. "Rejected prisoners often failed to appreciate the actual reasons they were not selected and thus rejected the system...."14 The work release program, however, was not the sole cause of unrest, but rather one contributing factor.

Another factor contributing to inmate unrest was one of George Randall's pet "progressive" programs. The Upward Bound program was designed to assist inmates preparing for college study. Twenty-six convicts participated in the educational program. Tom Gaddis, author of The Birdman of Alcatraz, was the director of the program. He was assisted by Ace Hays. Gaddis and Hays, in conjunction with George Randall, placed the pilot program into the prison despite the adamant objections of Warden Gladden. Gladden was slowly being undermined. Hays, a teacher in the program, was the author of "many articles promoting the violent overthrow of the United States government...."15 $\mathrm{He}$ had been arrested on previous occasions for violent protests in Portland. $\mathrm{He}$ advocated and distributed so-called "hate" literature within the prison. The Upward Bound program created friction among the inmates. The twenty-six enrolled in the program received special privileges. They were given special 
library hours, and special access to the canteen, exercise equipment, and a television. Hays, Gaddis, and the other instructors entered and left the prison "at will." They were not subjected to the same routine inspections as other guests and staff. Consequently, contraband and letters were smuggled in and out of the prison. Because of the Upward Bound staff and inmate-student freedom, discontent and disgust was bred among the prison's general staff and inmate population. There was no single effective control of the program and if measures were taken to control the organization, the program's leaders went directly to Randall to have their wants and needs met. The normal chain of command and all standard operating procedures were by-passed.

The crisis was seized by Oregon Legislature House Speaker F.F. "Monte" Montgomery as an opportunity. He saw the prison crisis as a political opportunity. Montgomery asserted that the Board of Control, comprised of the Governor, Secretary of State, and Treasurer, was sitting on its hands. Reports of weapons and narcotics ought to have been dealt with, and yet, McCall, Myers, and Straub were inactive, Montgomery believed. He sent Governor Tom McCall an "inflammatory" letter and demanded an investigation of the prison. ${ }^{16}$

Montgomery apparently believed that a crisis like the prison issue would give new vigor to his sagging campaign for Secretary of State. Montgomery was losing to McCall's associate, Clay Myers. Montgomery's tactics blew up in his face. The public perceived his campaign as a mudslinging affair in which Montgomery capitalized on a tragedy. Montgomery lost the election, but his 
campaign helped trigger violent unrest within the prison. Prisoners are alert readers of newspapers and capitalized on Montgomery's criticism in order to demand greater leniency. "They know when the mush is being stirred," McCall said, that this "is the time to strike."17

Convict Ronnie Wagner Hancock gave his analysis of the prison unrest. "With no outlet for your emotions, you become a mentally disturbed individual, or a vegetable," he said. "Today maybe we are animals...every man reaches his breaking point."18 The Oregon State Penitentiary had reached that breaking point. At 4:15 in the afternoon on March 9, 1968, a riot at the prison broke out. It began five minutes earlier when an inmate was pulled aside for a random search. The inmate, however, refused and commenced to quarrel with the guards on duty. The fight escalated when other inmates joined in the fracas. The convicts seized some forty hostages and threatened to kill one hostage every twenty minutes until the segregation and isolation block inmates were released. The leaders of the riot then seized the control center. Using crude knives, the inmates easily subdued the guards.

Three inmates attempted to escape by scaling a cyclone fence near a tower. A shot from the tower quickly ended the attempt. The tower guard was later reprimanded for shooting, although he prevented escape and prisoner access to other buildings which they would have destroyed. The number of rioting inmates grew to over 1100 . Thirty-six hostages were released for various reasons. Only Lieutenant Ralph E. Pribble, Sargeant R.D. Meyers, Lieutenant Hal Masterson, 
and Officer C.E. Mann remained in the hands of the angry convicts.

George Randall arrived on the scene and immediately gave orders that "there will be no shooting--no gas--no force."19 Randall was in command of the "outside forces," but was not in command of the crisis. Throughout the affair he "neither asked for nor looked to any of the experts available as to what should be done." ${ }^{\prime 20} \mathrm{He}$ failed to establish a command-post so that he could be found at any time. When the convicts heard Randall's orders they went on a rampage, free from fear. They looted, burned buildings, and destroyed the prison's grounds. Randall's order for "no shooting" effectively terminated the prison's riot control plan. A riot control plan is a confidential plan of procedures outlining the use of equipment, personnel, and whatever force the squad feels necessary to stop the riot. The Oregon State Penitentiary riot control squad was ready and armed. Yet, with Randall's order, they were rendered impotent. They stood impatiently, anxiously awaiting their chance to stop the riot. They watched the convicts loot, commit arson and physical abuse upon one another; they watched the work shops and cell blocks burn. All witnesses and the subsequent Grand Jury, with the exception of George Randall, agreed that the riot squad could have quickly ended the disturbance. The Marion County Grand Jury later testified that,

By nightfall, the buildings were burning; the commissary had been looted, blankets and bedding were brought to the yard by the inmates. Small make-shift tents sprang up. Convicts were seen eating fresh bread by the loaf, and sheetcakes by the dozen. They drank milk by the gallon and cooked meat and steaks over large bonfires built from the wreckage of the prison. The loud strains of steel guitars played in the background as a night of destruction, sexual perversion and homosexuality occurred. There were many 
assaults, several knifings, and total destruction of property. Taunting profanities were thrown to the guards whom they knew could not take action. ${ }^{21}$

The inside of the prison would have to burn as the outside forces were unable to act accordingly. Randall severed all standard procedures. This was his "baby" and he would nurse it his way.

Without consulting riot experts, the prison officials, or his political allies, Randall proceeded to the prison yard to talk to the inmates. None of the administrative staff at the prison were consulted, all of whom were trained, competent officials. Randall began negotiations with a body of convicts. The convict spokesmen were Billy Ray Bowling and Tony Graven. The convicts again requested the release of the segregation unit inmates. Randall would have released all of the convicts had it not been for the sound advice and intervention of an assistant. Randall did agree to "boss cons" being released to advise the rioters how to proceed. The press entered at this time and broadcast the crisis to the public at home. Randall's decision to allow press access to the riot endangered the lives of the press members as well as the staff members held hostage. The convicts then presented in front of the cameras their list of grievances and demands. They complained of cold food, improper medication, and the "Big Brother" policies of Warden Gladden. ${ }^{22}$ Their first demand was Gladden's resignation. Hours later the seventy-three year old warden retired. His rehabilitative and therapeutic policies only enflamed the passion for liberty and the riot was its result. "There is so much hate here," Graven told reporters, "that 
this is long overdue." 23

Randall patiently listened to the demands of the inmates. Graven told Randall, "We appreciate your sincerity. You've tried to help us here. If there were more of your kind, we'd be better off." ${ }^{24}$ Randall returned to discuss the negotiations with his staff.

At their second meeting Tony Graven was noticeably absent. His fellow inmates decided he was too militant and abandoned him in the selection of "The Committee." The committee was composed of six convicts: Ronnie Hancock, Richard Dornack, Lendel Buttram, Jimmie Ennis, Billy Ray Bowling, and Calvin Dow, Jr. The committee presented ten demands: Gladden's resignation, medical improvements, re-establishment of the inmate council, a new canteen, less forced savings, school and work release programs, improved correspondence and visiting policies, bath and entertainment enhancements, vocational programs, and clothing. Corrections personnel regard capitulation to inmate demands as weakness and ignorance. Randall, however, capitulated and agreed to respond to each of their demands. He looked over the prison grounds and saw no alternative. Over $\$ 1.8$ million in property had been destroyed. "When the smoke cleared and the ashes cooled, the Oregon riot had ended peacefully. Not one person had been injured."25 A substantial portion of the public, however, was angry because the rioting outlaws had not been "mowed down."26

The riot was essentially over by noon of March 10, 1968. One convict demand had already been met--Clarence Gladden had resigned. He had become 
more tolerant in his older years and the acceptance of his resignation was based more on his illness than on his penal philosophy. Gladden actually tendered his resignation three days before the riot. Governor McCall told him that he "...couldn't toss him to the wolves by accepting the resignation during this controversy." 27 In the previous legislature Gladden was so well-liked that the assembly passed a special "Gladden Bill" allowing him to stay on for as long as he wished. "Like J. Edgar Hoover, Gladden stayed on too long."28 Gladden's bout with cancer, however, sapped the strength from the warden. He no longer had the strength or power to control the prison. And so, in mid-March, 1968, Clarence Gladden retired. He came to Oregon amid controversy and would leave the prison in a similar storm.

The prison's crisis, however, did not sit solely on the shoulders of the aging warden, but also on George Randall. "Randall was a good man," said Governor McCall. $^{29}$ The evidence turned up by the Grand Jury investigating the riot shows otherwise, however. Randall came to Oregon in 1965, with a resume implying academic excellence and graduate work at Auburn, Georgetown, George Washington, and Wisconsin universities. He claimed to have served with the Federal Bureau of Investigation as an executive assistant to J. Edgar Hoover. The Grand Jury investigation proved all of these claims to be untrue. In fact, Randall never graduated from college. He was never an agent of the FBI, but only a messenger boy and typist for the Bureau for two years! In the years he claimed service to the FBI, he was actually working in an insurance company and later a 
furniture factory. There was not a single shred of evidence that Randall had any experience in corrections or penology. ${ }^{30}$

How then, did George Washington Randall deceive the Oregon public and obtain his position as Director of Corrections? Apparently in 1955, Randall, because of political connections, was appointed a "consultant" in the prison system of North Carolina. At the time, he was a salesman of prison-made leather goods. His connection to corrections went no futher than that. Two years later he joined the political machine of Democratic North Carolina Governor Luther H. Hodges and was appointed chairman of the Board of Parole and Probation. In 1961, with a growing list of false qualifications, Randall was appointed Director of Corrections in North Carolina. He was fired in 1964 when Governor Daniel K. Moore took office. ${ }^{31}$

The Marion County Grand Jury exposed Randall and his lack of qualifications. Governor McCall rankled at the report and called it a "hatchet job." ${ }^{132}$ The report was written under the supervision of District Attorney General Gary Gortmaker and ripped open a painful schism in the corrections field. The political interference in penology was exposed to the public here. "The breakdown of custody," the report reads, "together with general unrest, was the greatest contributing factor to the riot." ${ }^{13}$ The crisis did not hurt McCall, however. The governor was returning from a visit with Nelson Rockefeller to assess the crisis when he came upon his "lucky break." The passenger next to McCall was Charles Hagen, Assistant Director of the U.S. Bureau of Prisons. 
McCall introduced Hagen to the press in Oregon as a "special troubleshooter."134 Hagen later filed a report recommending the prison improve its communications, inmate employment, the prison's central control room, inmate visiting policy, and private bathing.

The riot had achieved its goal---reform. In 1969, the legislature abolished the Board of Control and thereby gave the power back to a central source. The prison authority was no longer in a thousand strands. Shortly thereafter, George Randall resigned and was replaced by John J. Galvin as Director of Corrections. Galvin had two decades of service in penology at federal prisons in Kentucky, Oklahoma, and recently served as Assistant Director of the Bureau of Prisons. ${ }^{35}$ The penal field in Oregon was now completely professionalized and bureaucratized. Gladden's successor, Hoyt Cupp, joined Galvin in reforming and reshaping the prison's procedural and policy base. In early 1969, Cupp assessed the prison's problems and took measures to stop them before it erupted into a crisis. The riot of 1968 resulted in a contraband search and the development of a psychiatric security unit at the penitentiary. A new approach to inmate classification and counseling was experimented in cell block "A."

Times had changed, but Warden Gladden and George Randall did not. They were replaced by those who could change and adapt to the dynamic sociopolitical forces inside and outside the prison's walls. The 1960s saw the penal field adopt a reparative and reactive approach. The prisoner's rights movement had made a tremendous impact. The prison's bureaucratic structure was fortified. 
Documentation and psychological, sociological, and legal consultants further heightened the bureaucratic "gargantuan." Administrators, after the riot, were drawn from a pool of more highly educated candidates and possessed less despotic characteristics. Prisoners and staff alike were protected by procedural insurance and guarantees. The riot initiated a strong public awareness. Oregonians saw the disastrous potential in the prison. Political awareness of the prison was made more acute and with heightened attention came increased hope and higher frustration. A demoralized staff resented its conditions in comparison to the improving conditions of the inmate's life. The crisis in the prison is a perpetual one. There is no penal solution that does not breed a new crisis.

The eternal crisis of the prison will be resolved only through innovative and revolutionary policy; a policy we will not likely see in our own lifetime. The crisis of 1968 is not so far different from that first crisis in 1866 . The history of the Oregon State Penitentiary has involved one hundred years of crisis, stagnation, and reform; it has been one hundred years of financial, political, and physical abuse. 


\section{ENDNOTES}

${ }^{1}$ Oregonian, 1 April 1953, p. 1.

${ }^{2}$ Oregonian, 11 July 1953, p. 1.

${ }^{3}$ Oregonian, 13 July 1953, p. 1.

${ }^{4}$ Oregonian, 14 July 1953 , p. 1.

5Ibid., p. 12. 1495-1.

${ }^{6}$ Papers of the Oregon Prison Association, Oregon Historical Society, MSS-

${ }^{7}$ Ibid.

${ }^{8}$ Oregon State Correctional Superintendents: Paul J. Squire, 1 July 1957-30 September 1964; Richard J. Williard, 1 October 1964-2 July 1967; Charles W. Pfeiffer, 3 July 1967-31 October 1967; Amos Reed, 1 November 1967-16 August 1969. Oregon Womens Correctional Center Superintendents: Clarence Gladden, 5 January 1965-30 April 1966; Genevieve V. Calloway, 1 May 1966-26 July 1972. Department of Corrections Director: George W. Randall, 25 October 1965-10 June 1968; Joe Thimm, 11 June 1968-31 August 1968.

${ }^{9}$ George Randall, "Minutes of the Meeting, Corrections Division Advisory Board," Papers of the Oregon Prison Association, Oregon Historical Society, MSS-1495-1.

${ }^{10}$ Ibid.

11"Marion County Grand Jury Report on the Oregon State Penitentiary," January 1968, p. 5.

${ }^{12}$ Ibid., pp. 4-5.

${ }^{13}$ Ibid., p. 7.

${ }^{14}$ Ibid., p. 8.

${ }^{15}$ Ibid., p. 9. 
${ }^{16}$ Thomas Lawson McCall with Steve Neal, Tom McCall: Maverick, (Portland: Binford and Mort, 1977), p. 99.

${ }^{17}$ Ibid, pp. 99-100.

${ }^{18}$ Oregonian, 11 March 1968, p. 26.

19'Marion County Grand Jury Report", p. 17.

${ }^{20}$ Ibid.

${ }^{21}$ Ibid., p. 11.

${ }^{22}$ Oregonian, 10 March 1968, p. 1.

${ }^{23}$ Ibid.

${ }^{24}$ Ibid.

${ }^{25}$ McCall and Neal, Tom McCall: Maverick, p. 101.

${ }^{26}$ Ibid, p. 100.

${ }^{27}$ Ibid.

${ }^{28}$ Ibid.

${ }^{29}$ Ibid., p. 101.

${ }^{30 "}$ Marion County Grand Jury Report", p. 4.

${ }^{31}$ Ibid.

${ }^{32}$ McCall and Neal, Tom McCall, p. 98.

33"Marion County Grand Jury Report", p. 4.

${ }^{34} \mathrm{McC}$ Call and Neal, p. 98.

35."Minutes of the Meeting, Corrections Advisory Board", Papers of the Oregon Prison Association, Oregon Historical Society, MSS-1495-1. 


\section{CHAPTER IX}

\section{CONCLUSION}

Power tends to corrupt and absolute power corrupts absolutely. -Lord Acton (1834-1902)

The pathologies of the Oregon State Penitentiary are painfully clear. Its symptoms are apparent: riots, resignations, and escapes. One contributing factor to the paradox and pathology of the prison is the administration's continual abuse of the institution as a tool of financial, physical, and political power. Power corrupted the governors, the wardens and superintendents, and the prison staff. They exploited their political connections, pocketed public funds, and abused the inmates. The inmates, staff, and superintendents to some degree, were sacrificed for the preservation of power. As a consequence the ineffective institution has been perpetuated and fortified within the public mind. It is for this reason that the prison's history has taken a cyclical form.

It has become painfully obvious that the rhetoric of reformers influenced conditions within the prison very little. The prison's biennial reports revealed the institution's deplorable conditions; the newspapers uncovered crisis and stagnation. It was and remains a violent, overcrowded institution. It is a warehouse of disorder. Yet, while the penitentiary was abstracted to the periphery of social 
consciousness it remained central to public policy. The "gargantuan enterprise" still grows.

The founders of the Oregon State Penitentiary created the institution in full expectation to bring stability and security to the citizens of Oregon. They had hoped to create a system of order based on reason and structure, but had developed an institution of crisis. But crisis in the prison did not lead to the institution's demise, but to its fortification. The public became further convinced that the inmates were justly incarcerated and that harsher sentencing, conditions, and policy ought to be explored to insure their safety.

We have accepted the penitentiary as an inevitable ingredient of our society, however contrary to our principles of liberty that may be. The inherent pathologies of the prison have been inherited by every generation of administrators at the Oregon State Penitentiary. Every generation of Oregonians has inherited the problem of crime and the dilemma of how to respond to it. The heirs of the dilemma, however, need not respond in the same ineffective, inhumane, and antiquated ways. The Oregon State Penitentiary is a prison full of incarcerated men. Furthermore, it is an institution of limited concepts and trapped intentions. To liberate one is to free the other. And to limit one's self to only one possibility is to limit the potential of Oregon's citizens. The ineffective responses of the prison administrators has helped perpetuate the cycle of crisis and equilibrium within the Oregon State Penitentiary. 


\section{SELECTED BIBLIOGRAPHY}

\section{NATIONAL SOURCES}

Cardozo-Freeman, Inez. The Joint: Language and Culture in a Maximum Security Prison, Springfield, IL: Charles C. Thomas, Publisher, 1984.

Carleton, Mark. Politics and Punishment: The Histoy of the Louisiana State Penal System, Baton Rouge,LA: Louisiana State University, 1971.

Clemmer, Donald. The Prison Community, New York: Holt, Rinehart, and Winston, 1940.

Cohen, Stanley and Scull, Andrew. Social Control and the State, New York: St. Martin's, 1983.

Cohen, Stanley. Visions of Social Control: Crime, Punishment, and Classification, Cambridge: Polity Press, 1985.

Crowe, Jesse Crawford. "The Origin and Development of Tennessee's Prison Problem, 1831-1871," Tennessee Historical Quarterly, June 1956, pp. 111135.

Foucault, Michel. Discipline and Punish: The Birth of the Prison, New York: Pantheon Books, 1977.

Fox, Vernon. Violence Behind Bars: An Explosive Report on Prison Riots in the United States, Westport, CT: Greenwood Press, 1956.

Freedman, Estelle B. Their Sister's Keepers: Women's Prison Reform in America, 1830-1930, Ann Arbor: University of Michigan Press, 1981.

Jacobs, James. New Perspectives on Prisons and Imprisonment, Ithaca, NY: Cornell University Press, 1983.

Jacobs, James. Stateville: The Penitentiary in Mass Society, Chicago: The University of Chicago Press, 1977. 
Johnson, Alexander, ed. Proceedings of the National Conference of Charities and Corrections, Portland, OR: Fred J. Heer Press, 1905.

Johnson, Lester Douglas. The Devil's Front Porch, Lawrence, KS: The University Press of Kansas, 1970.

Kimball, Peter and Useem, Bert. States of Siege: U.S. Prison Riots, 1971-1986, New York: Oxford University Press, 1989.

Lewis, W. David. From Newgate to Dannemora: The Rise of the Penitentiary in New York, 1796-1848, Ithaca, NY: Cornell University Press, 1965.

McCoy, John. Concrete Mama: Prison Profiles from Walla Walla, Columbia, MO: University of Missouri Press, 1981.

McKelvey, Blake. American Prisons: A History of Good Intentions, Montclair, NJ: Patterson Smith, 1977.

Morris, Roger. The Devil's Butcher Shop: The New Mexico Prison Uprising, New York: Franklin Watts, 1983.

Osborne, Thomas Mott. Society and Prisons: Some Suggestions for a New Penology, New Haven: Yale University Press, 1916.

Osborne, Thomas Mott. Within Prison Walls, Montclair,NJ: D. Appleton and Co., 1914.

Owens-Adair, Bethenia. Human Sterilization: Its Social and Legislative Aspects, Portland, OR: Bethenia Owens-Adair, 1922.

Pell, Eve, ed. Maximum Security: Letters from California's Prisons, New York: E.P. Dutton and Co., Inc., 1972.

Pontell, Henry. A Capacity to Punish: The Ecology of Crime and Punishment, Bloomington, IN: Indiana University Press, 1984.

Rafter, Nicole Hahn. Partial Justice: Women in State Prisons, 1800-1935, Boston: Northeastern University Press, 1985.

Rothman, David J. The Discovery of the Asylum: Social Order and Disorder in the New Republic, Boston: Little, Brown, and Co., 1971. 
Sykes, Gresham. The Society of Captives: A Study of a Maximum Security Prison, Princeton,NJ: Princeton University Press, 1958.

Toch, Hans. Police, Prisons, and the Problem of Violence, Rockville, MD:

National Institute of Mental Health Center for Studies of Crime and Delinquency, 1977.

Useem, Bert. "Disorganization and the New Mexico Prison Riot of 1980", American Sociological Review, October 1985, pp. 677-688.

Wright, Erik Olin. The Politics of Punishment: A Critical Analysis of Prisons in America, New York: Harper and Row, 1973.

\section{REGIONAL SOURCES}

Books and Articles

Bedau, Hugo A. "Capital Punishment in Oregon, 1903-1964", Oregon Law Review, December 1965.

Bone, Arthur H. ed. Oregon Cattleman, Governor, Congressman: Memoirs and Times of Walter M. Pierce, Portland: The Oregon Historical Society, 1981.

Carey, Charles H. General History of Oregon, Portland: Binfords and Mort, 1922.

Carter, W.N. Harry Tracy: The Desperate Western Outlaw, Chicago: Laird and Lee, 1903.

Chipman, Art. Tunnel 13, Medford, OR: Pine Cone Publishers, 1977.

Dodds, Gordon B. Oregon, New York: W.W. Norton and Company, 1977.

Dodds, Gordon B. The American Northwest: A History of Oregon and Washington, Arlington Heights, IL: The Forum Press, Inc., 1986.

Gaddis, Thomas E. and Long, James O. Killer: A Journal of Murder, New York: The MacMillan Comapny, 1970.

Howard, John and Sturholm, Larry. All For Nothing: The True Story of the Last Great American Train Robbery, Portland: BLS Publishing Co., 1976. 
Kelley, Joseph. Thirteen Years in the Oregon Penitentiary, Portland, 1908.

Larsell, O. "History of Crae of Insane in the State of Oregon", Oregon Historical Quarterly, December 1945, pp. 295-326.

Lowe, Beverly Elizabeth. John Minto: Man of Courage, 1822-1915, Salem: Kingston Price and Company, 1980.

MacColl, E. Kimbark. The Growth of a City: Power and Politics in Portland, Oregon, 1915 to 1950, Portland: The Georgian Press Company, 1979.

McAfee, Ward. "The Formation of Prison-Management Philosophy in Oregon, 1843-1915", Oregon Historical Quarterly, February 1990, pp. 259-284.

McCall, Thomas L. and Neal, Steve. Tom McCall: Maverick, Portland: Binford and Mort, 1977.

Minto, John. Rhymes of Early Life in Oregon and Historical and Biographical Facts, Salem: Statesman Publishing Co., 1915.

\section{Unpublished Sources}

Johnson, J.R. "The Penitentiary, Our First Institution", Oregon State Penitentiary Archives.

McConnell, Gregory Clark. "A Historical Geography of the Chinese in Oregon", Master's Thesis: University of Oregon, Dept. of Geography, 1979.

Stratton, Julius Augustus. "Autobiographical Sketch of Julius Augustus Stratton", Portland: Oregon Historical Society.

Walls, Florence. "The Letters of Asahel Bush to Matthew P. Deady, 1851-1863", B.A. Thesis: Reed College, 1941.

\section{Newspapers}

Lend A Hand, Oregon State Penitentiary publication, 1903-1919.

Oregonian

Oregon Journal 
Oregon Spectator

Oregon Statesman

Portland Telegram

Shadows, Oregon State Penitentiary magazine.

State Records

Biennial Report of the Secretary of State of the State of Oregon, Salem: W.A. McPherson, State Printer, 1870.

Biennial Report of the State Board of Charities and Corrections, Portland: F.W. Baltes and Co., 1892.

Biennial Report of the Superintendent of the Penitentiary of the State of Oregon, Salem: Eugene Semple, State Printer, 1872.

Biennial Report of the Superintendent of the Penitentiary of the State of Oregon, Salem: Mart V. Brown, State Printer, 1878.

Biennial Report of the Superintendent of the Penitentiary of the State of Oregon, Salem: W. P. Keady, State Printer, 1880.

Biennial Report of the Superintendent of the Penitentiary of the State of Oregon, Salem: W.H. Byars, State Printer, 1885.

Biennial Report of the Superintendent of the Penitentiary of the State of Oregon, Salem: W. H. Byars, State Printer, 1887.

Biennial Report of the Superintendent of the Penitentiary of the State of Oregon, Salem: Frank C. Baker, State Printer, 1889.

Biennial Report of the Superintendent of the Penitentiary of the State of Oregon, Salem: Frank C. Baker, State Printer, 1891.

Biennial Report of the Superintendent of the Penitentiary of the State of Oregon, Salem: Frank C. Baker, State Printer, 1893.

Biennial Report of the Superintendent of the Penitentiary of the State of Oregon, Salem: Frank C. Baker, 1894.

Biennial Report of the Superintendent of the Penitentiary of the State of Oregon, Salem: W.H. Leeds, State Printer, 1897. 
Biennial Report of the Superintendent of the Penitentiary of the State of Oregon, Salem: W.H. Leeds, State Printer, 1899.

Biennial Report of the Superintendent of the Penitentiary of the State of Oregon, Salem: W.H. Leeds, State Printer, 1901.

Biennial Report of the Superintendent of the Penitentiary of the State of Oregon, Salem: W.H. Leeds, State Printer, 1902.

Biennial Report of the Superintendent of the Penitentiary of the State of Oregon, Salem: J.R. Whitney, State Printer, 1904.

Biennial Report of the Superintendent of the Penitentiary of the State of Oregon, Salem: J.R. Whitney, State Printer, 1906.

Biennial Report of the Superintendent of the Penitentiary of the State of Oregon, Salem: Willis S. Duniway, State Printer, 1908.

Biennial Report of the Superintendent of the Penitentiary of the State of Oregon, Salem: Willis S. Duniway, State Printer, 1912.

Report of the Corrections Division Advisory Board to the Oregon State Board of Control, December 1968, Oregon Historical Society

"General Rules for the Inmates of the Oregon State Penitentiary", January 1, 1928 Portland: Oregon Historical Society.

"Grand Jury Report, January Term 1968, on the Oregon State Penitentiary", Portland: Oregon Historical Society.

"Great Registry", vol.1., 1854-1877. Salem: Oregon State Archives.

The Inaugural Address of Governor L.F Grover, Salem: T Patterson, State Printer, 1870.

"Prisoner Disciplinary Record, 1909-1929", Salem: Oregon State Archives.

Report of the Commission to Investigate the Oregon State Penitentiary, Portland: 1917.

Report of the Joint Committee appointed by the Legislative Assembly to Investigate the Affairs of the Penitentiary, Salem: Mart V. Brown, State Printer, 1874. 